\title{
INTERPRETAÇÃO DO CORPO A PARTIR DE SEIS VÍDEOS INTEGRANTES DA VIDEOTECA DO CENTRO DE FORMAÇÃO DOS TRABALHADORES DA SAÚDE DA SECRETARIA MUNICIPAL DA SAÚDE DE SÃO PAULO.
}

\author{
Dissertação de Mestrado \\ apresentada ao Departamento de \\ Prática de Saúde Pública da \\ Faculdade de Saúde Pública da \\ Universidade de São Paulo
}

ORIENTADOR: PROF ${ }^{A}$. DRA. NELLY MARTINS FERREIRA CANDEIAS

São Paulo 
Autorizo, exclusivamente para fins acadêmicos e científicos, a reprodução total ou parcial desta tese, por processos fotocopiadores.

Assinatura:

Data: 
"A metafisica do corpo se entremostra nas imagens. A alma do corpo modula em cada fragmento sua música de esferas e de essencias além de simples carne e simples unhas.

Em cada silêncio do corpo identifica-se a linha do sentido universal que à forma breve e transitiva imprime a solene marca dos deuses e do sonho."

Carlos Drummond de Andrade Trecho do poema "A metafisica do corpo" 


\section{AGRADECIMENTOS}

À Prof ${ }^{a}$. Dra NELLY MARTINS FERREIRA CANDEIAS pela orientação e pelo estímulo, decisivos para a concretização deste trabalho

À Prof ${ }^{a}$. Dra MARIA HELENA VILLAS BÔAS CONCONE pelo interesse, apoio e sugestões

Ao Prof. Dr FERNANDO LEFĖVRE pelas contribuições fundamentais à realização do estudo. 


\section{RESUMO}

Nazário CL. Interpretação do corpo a partir de seis vídeos integrantes da videoteca do Centro de Formação dos Trabalhadores da Saúde da Secretaria Municipal da Saúde de São Paulo. São Paulo; 2001. [Dissertação de Mestrado - Faculdade de Saúde Pública da USP]

O objetivo do estudo é contribuir para a análise e avaliação dos recursos educativos utilizados nas ações de promoção e educação em saúde. Foram selecionados seis vídeos do acervo da videoteca do Centro de Formação dos Trabalhadores da Saúde (CEFOR) sobre os assuntos serviços de saúde/ serviços públicos, saúde da mulher e doenças sexualmente transmissíveis/ aids, sendo três de fiç̧ão e três do gênero reportagem/ documentário.

Os materiais foram analisados buscando interpretar quais os significados da configuração do corpo nas mensagens veiculadas. Para orientar a análise utilizaram-se as categorias de corpo individual/ existencial, social e político. Observou-se também como a mensagem foi estruturada segundo a forma de utilização de alguns recursos de linguagem audiovisual como roteiro, edição, movimento de câmera, enquadramento, áudio e cenário.

Foram identificadas algumas oposições básicas através das quais pudemos interpretar os significados atribuídos às várias dimensões do corpo. Dentre elas podemos citar as oposições natureza/ cultura, indivíduo/ sociedade e parte/todo.

A partir da análise foram elaboradas algumas considerações e sugestões com relação à utilização dos recursos de linguagem visando uma maior eficácia na comunicação, assim como reflexões a respeito das concepções de corpo apresentadas.

Descritores. Comunicação. Recursos audiovisuais. Corpo humano. Promoção da saúde. Educação em saúde. 


\section{SUMMARY}

Nazário CL. Interpretação do corpo a partir de seis vídeos integrantes da videoteca do Centro de Formação dos Trabalhadores da Saúde da Secretaria Municipal da Saúde de São Paulo. [ Body interpretation from six videos of Centro de Formação dos Trabalhadores da Saúde of Secretaria Municipal da Saúde de São Paulo's video collection]. São Paulo (BR) ; 2001. [Dissertação de Mestrado - Faculdade de Saúde Pública da Universidade de São Paulo]

This study objective is to contribute with the analysis and evaluation of educational resources used in promotion and education actions in health area. Six videos about health service/ public services, women health and sexually transmissible illnesses/aids, being three of fiction and three of reporting/ documentary, have been selected from Centro de Formação dos Trabalhadores da Saúde (CEFOR) video collection.

The material was analyzed with the objective of interpret which are the meanings of body configuration in the presented messages. To orient the analysis, individual/existential, social and politics body categories were used. It was also observed how the message was structured according to the utilization form of some audiovisual language resources such as script, edition, camera movement, frame, audio and scenery.

It were identified some basic oppositions through which we could interpret the meanings given to the several body dimensions. Among them we can mention nature/ culture, individual/ society and part/ whole oppositions.

From the analysis some considerations and suggestions related to the language resource utilization were elaborated aiming a better communication effectiveness, as well as thoughts about the presented body conceptions.

Descriptors. Communication. Audiovisual aids. Human body. Health promotion. Health education 


\section{ÍNDICE}

1. INTRODUÇÃO 1

1.1 O Cefor e a videoteca 2

1.2 Revisão bibliográfica referente ao tema da comunicação e ao tema do "corpo" na área da saúde

2. ASPECTOS TEÓRICOS DO ESTUDO 10

2.1 Corpo como categoria analítica 10

2.2 Comunicação $\quad 21$

2.3 Comunicação, Educação e Promoção à saúde: algumas considerações

3. OBJETIVOS 37

3.1 Geral 37

3.2 Específicos 37

4. METODOLOGIA 38

$4.11^{\mathrm{a}}$ Fase 38

$4.22^{\mathrm{a}}$ Fase 38

$4.33^{\mathrm{a}}$ Fase $\quad 40$

$4.44^{\mathrm{a}}$ Fase $\quad 42$

5. RESULTADOS E DISCUSSÃO DE DADOS: SINOPSE, DESCRIÇÃO DE SEQÜÊNCIAS E INTERPRETAÇÃO DE CADA VÍDEO SELECIONADO

5.1 Vídeo 1: Divina Previdência 47

5.2 Vídeo 2: Atendimento Médico 59

5.3 Vídeo 3: Amamentação: vamos recuperar esta prática? 68

5.4 Vídeo 4: Denise $\quad 75$ 
5.5 Vídeo 5: Mancha de Batom

5.6 Vídeo 6: Quem vê a cara, vê Aids

5.7 Quadros descritivos

6. CONSIDERAÇÕES FINAIS E CONCLUSÕES

8. ANEXO - Assuntos reagrupados em categorias mais genéricas 


\section{INTRODUÇÃO}

Este estudo aborda um tema que diz respeito a diferentes áreas do saber, tais como saúde pública, promoção e educação em saúde e comunicação. Na medida em que a imagem do corpo nos vídeos é o foco de análise, tratamos também da questão da interpretação dos significados, tema este amplamente abordado pela sociologia e pela antropologia. Dessa forma estaremos utilizando vários esquemas teóricos destas áreas na análise e na interpretação do tema escolhido.

Partindo do assunto mais geral, que seria a saúde, podemos ressaltar que esta é uma área que engloba várias disciplinas, com o objetivo de analisar e auxiliar o ser humano em sua busca de prevenção de doenças e de cura. Porém "ser humano" não é um conceito abstrato, uma vez que se concretiza em um corpo. Esse corpo, por sua vez, não se limita a um simples invólucro, com um conjunto de órgãos. Ele possui várias dimensões, biológicas, emocionais, sociais, políticas, que se encontram interligadas. Além disso é o corpo de uma pessoa que vive no aqui e no agora, ou seja, em tempo e espaços definidos, com uma história e biografia constituídas individual e coletivamente.

Com relação ao tema da comunicação pode-se perceber que é um instrumento de fundamental importância na busca de um relacionamento com o outro, que vise a promoção da saúde, a prevenção e a cura de doenças, sendo imprescindível para que a troca de conhecimentos efetivamente se realize. Numa visão de promoção e educação em saúde participativa, busca-se não somente a transmissão de conhecimentos, mas uma troca de saberes e práticas. Para isso é necessário tanto o autoconhecimento, quanto o conhecimento de quem de fato é esse "outro".

A partir da análise dos vídeos utilizados na área de saúde buscou-se compreender como é percebido o corpo do "outro. Essa visão, configurada nas imagens e sons apresentados nos vídeos, demonstra de que maneira $o$ corpo é interpretado. Acreditamos que o caminho da reflexão sobre os sentidos atribuídos ao corpo, nos materiais videográficos produzidos, pode 
fornecer elementos que propiciem ultrapassar um aspecto meramente descritivo ou instrumental dos recursos audiovisuais.

Dessa forma, nos utilizamos de conceitos e categorias construídos nas diversas áreas citadas acima, apresentados no capítulo intitulado "Aspectos teóricos", que fundamentaram a análise e interpretação dos materiais selecionados.

\section{O Cefor e a Videoteca}

O Centro de Formação dos Trabalhadores da Saúde, CEFOR, criado em 1990 pelo Decreto Municipal 28625 de 30/03/90, foi estruturado como órgão integrante do Centro de Recursos Humanos da Secretaria Municipal de Saúde de São Paulo "tendo como objetivo o apoio à realização de ações descentralizadas de formação e desenvolvimento de trabalhadores da saúde. Estas ações visam, através da integração crítica entre ensino e trabalho e a partir das necessidades e realidades locais, a melhoria e a transformação da qualidade dos serviços e a construção do Sistema Único de Saúde." (Secretaria Municipal de Saúde de São Paulo, 1992, p.5)

O Centro, no seu início, foi composto por quatro núcleos - formação, desenvolvimento, conselho de ensino e multimeios - que funcionavam através de projetos. O Núcleo de Multimeios "é responsável pela biblioteca, videoteca e pelo Centro de Documentação, além da organização, produção e difusão de materiais de apoio gráfico e audiovisual que se façam necessários aos projetos e às demais atividades de formação e de desenvolvimento" (Secretaria Municipal de Saúde de São Paulo,1992,p.7).

Dessa forma, desde a sua inauguração em agosto de 1990, a videoteca tem sido estruturada no Núcleo de Multimeios mediante a aquisição de fitas de vídeo por compra, doações ou permutas . No início foi realizado um levantamento, junto a instituições que possuíam produções audiovisuais nas áreas da saúde, social e educacional, com o objetivo de selecionar títulos de nosso interesse. Foram contatadas: Fundação Oswaldo Cruz, NUTES (Núcleo de Tecnologia Educacional para a Saúde) da Universidade Federal do Rio de Janeiro, Setor de Comunicação Social do 
Ministério da Saúde, Secretaria de Estado da Saúde de São Paulo, ABVP (Associação Brasileira de Vídeo Popular), Rede Mulher, ECOS ( ONG de Educação, Comunicação e Sexualidade), Secretarias de Saúde de outros Estados ou Municípios, que produziram vídeos ( Santa Catarina, Minas Gerais, Maranhão), FDE (Fundação para o Desenvolvimento da Educação), entre outras.

Vários títulos foram sugeridos ou doados por especialistas de saúde de várias categorias profissionais. $\mathrm{O}$ acervo conta atualmente com mais de 300 títulos. Esses materiais são utilizados em cursos, palestras e treinamentos em unidades de saúde, creches, escolas, empresas, etc. O presente estudo diz respeito a alguns vídeos integrantes desta videoteca, cujo acervo, até o momento da elaboração do último catálogo, em 1997 , contabiliza um total de 318 títulos.

\section{Revisão bibliográfica referente ao tema da comunicação e ao tema do "corpo" na área da saúde}

No campo da educação discute-se freqüentemente a utilização dos meios de comunicação. Sua presença é uma realidade que a escola, e outras instituições que visam um trabalho educativo, não podem ignorar. "A onipresença da imagem (....) é uma das características mais singulares e importantes do mundo atual. " (GUTIÉRREZ , 1978) Existe ampla literatura, tanto na área da comunicação quanto na da pedagogia ,que analisa o uso dos recursos audiovisuais na educação, provenientes ou não dos meios de comunicação de massa. Há autores que abordam questões relativas à leitura dos meios de comunicação. MORAN (1993) propõe uma educação para a comunicação entendida "como intervenção organizada na sociedade para conseguir percepções mais coerentes da interação comunicaçãosociedade, com metodologias que dêem conta de níveis abrangentes das relações focalizadas." (p.11) 
Outros autores tentam entender a estrutura das imagens e mensagens (GIACOMANTONIO, 1981), visando compreender os processos de codificação e decodificação, com ênfase no processo perceptivo (GUTIÉRREZ, 1978). Existem publicações que abordam questões mais técnicas relacionadas ao tema (FERREIRA E SILVA, 1986) em que apresentam informações sobre como produzir e utilizar os recursos audiovisuais. Outros autores abordam o processo de comunicação sob pontos de vista sociológico e político. Ao inserir a discussão da comunicação como uma questão da cultura (BARBERO, 1997), ressalta-se não apenas os meios e as tecnologias, mas também as mediações que se estabelecem através da cultura , segundo os significados que aí configuram e condicionam os processos de comunicação.

As mensagens transmitidas através das imagens propiciam formas variadas de leituras, em função das experiências de vida de cada um. "O indivíduo permanece, às vezes, insensível a certos elementos que para outros são importantes, e capta e cataloga como importantes aqueles que sua sensibilidade soube abstrair do conjunto. Entretanto não se deve esquecer que as diferenças de leitura são tais, justamente porque existe uma linguagem padrão, que é a das imagens." (GIACOMANTONIO,1981) Esta "sensibilidade" de que o autor nos fala é condicionada tanto por vivências individuais como coletivas. As possibilidades apontadas podem se tornar valiosas para ações preventivas na área de saúde. Edgar Morin escrevendo sobre o cinema, aponta que "a imagem cinematográfica, à qual falta a força probatória da realidade prática, detém um tal poder afetivo que justifica um espetáculo. À sua realidade prática desvalorizada corresponde uma realidade afetiva eventualmente acrescida, realidade essa a que chamamos o encanto da imagem." (MORIN,1983, pg153)

Dois outros trabalhos sobre comunicação apresentam interesse para o presente estudo em termos da metodologia utilizada. Um deles aborda a imagem que se forma sobre o saber psicanalítico, analisando as representações populares da psicanálise na atualidade através do cinema de gênero policial (BIRMAN,1996). O autor analisa três filmes que considera 
tipos ideais, por representarem a forma como a sociedade enxerga os psicanalistas. "É esta configuração macabra do analista que se desenha invariavelmente nas produções cinematográficas recentes" (BIRMAN,1996,p.21). As questões levantadas a partir do discurso cinematográfico refletem não apenas a visão que os meios de comunicação têm - que indicam suas raízes sócio-culturais - , mas questionamentos e disputas internas da própria ciência (psicologia/psiquiatria). Em relação à metodologia do estudo relata o autor:

Do ponto de vista do procedimento teórico e do método de trabalho forjado pela nossa leitura destas narrativas cinematográficas, diremos que elaboramos um tipo ideal a partir de alguns exemplos bem escolhidos, no sentido teórico que Weber encarou este conceito(....) Para realizar a construção de um tipo ideal, tal como Weber o concebeu, bastam poucos exemplos, mas que estes não poderiam ser quaisquer; é necessário que eles sejam bastante significativos, para fundar a consistência teórica do tipo ideal em questão. Para isso, convém selecioná-los cuidadosamente no nível da realidade empírica, tanto para construir o tipo ideal quanto para sublinhar os seus traços (BIRMAN,1996,p.24).

Outro estudo interessante que tem uma interface com a saúde é o de MELO (1993) . Ao analisar os vídeos produzidos em função do movimento feminista, entre os anos 1981 e 1992, levanta diversos pontos com relação à linguagem audiovisual utilizada. Segundo a autora, o depoimento - a história de vida das mulheres- é um dos fios condutores da narrativa que vai de encontro àquilo que os movimentos privilegiam, ou seja, a experiência e o cotidiano enquanto forma de atuação e mobilização das mulheres (p.48/49). A autora coloca ainda que uma das características destes programas é a preferência em gravar a mulher no espaço público, na busca de articular a vida privada com a pública (p.51/52). 
Levantamento realizado na base Medline aponta alguns estudos sobre o tema comunicação, vídeo e saúde, dando um panorama dos tipos de trabalhos realizados. Entre os artigos selecionados, alguns dizem respeito ao uso dos vídeos produzidos para pequenas e/ou específicas audiências. No geral os trabalhos dizem respeito à relação profissional e paciente - seja em termos de avaliação da mesma ou com objetivos de treinamento - à educação do paciente ou, em alguns casos, com objetivos explícitos de promoção à saúde.

Há um estudo que avalia a eficácia de um programa com vídeos sobre prevenção de Aids com adolescentes e pais (WINETT et. al.,1993). Sessenta e nove famílias com adolescentes de 12 a 14 anos foram divididas em dois grupos e acompanhadas por 4 meses; a um deles foi apresentado vídeo com informações e treinamento de habilidades e ao outro grupo controle foi apresentado apenas um vídeo informativo. A elaboração dos materiais - vídeo e manual - foi baseada em pesquisas prévias para adaptar a linguagem às características do público. Em cenas voltadas aos adolescentes, utilizaram-se apresentações com formato ágil, rápido e com recursos dramáticos. Os resultados do estudo sugerem o vídeo como um recurso efetivo no desenvolvimento de conhecimentos e capacidades para resolução de problemas com relação à prevenção da AIDS. Ressaltam, porém a especificidade do estudo com relação ao público, constituído por pais motivados e famílias de baixo risco. Neste contexto, os autores consideram que os resultados, principalmente com relação aos pais, são promissores, havendo, entretanto, dificuldade de interpretar os resultados do impacto sobre os adolescentes.

Estudo desenvolvido por DODD e colaboradores (1989) relata o desenvolvimento de um material auto-instrucional em vídeo para leitura labial. Outro estudo utiliza o vídeo como um dos recursos para que mães possam elencar termos que possam descrever os sinais e sintomas de doenças respiratórias agudas, para que um trabalho de prevenção possa utilizar linguagem e conceitos adequados e eficientes (RYAN et. al. , 1996). Visando a produção de vídeos para educação sobre câncer, pesquisadora 
ressalta a necessidade de estudar a audiência, para que o conteúdo apresentado possa ir de encontro aos interesses dos espectadores/pacientes (MEADE, 1996). Considera muito importante incluir percepções e conhecimentos do público alvo desde o início do processo de produção do vídeo, pois desta forma os conteúdos abordados serão mais adequados à sua realidade, adquirindo uma maior significação. Esta opção deriva de uma visão deste público como sujeito do conhecimento. Além disso, salienta aspectos práticos da produção de um vídeo (pré e pósprodução, orçamento, elaboração do roteiro, narração, locações, etc).

São apresentados outros relatos do uso do vídeo em saúde , como, por exemplo, em treinamento de pessoal na atenção médica e odontológica, visando melhorar a comunicação com pacientes com retardo mental (HARPER \& WADSWORTH, 1992). Outros autores apresentam uma experiência com gravação em vídeo de consultas médicas visando, entre outros, compreender e interpretar a comunicação entre médicos e pacientes (ARBORELIUS \& TIMPKA, 1990).Conclui-se que é um método válido para avaliar comportamentos e que, apesar da influência da presença da câmera ser maior para os profissionais, este efeito é apenas marginal. Artigo escrito por MAKOUL e colaboradores (1995) apresenta trabalho sobre a comunicação médico-paciente com relação à prescrição de medicamentos. Os autores estavam interessados em saber como a comunicação, durante as consultas, poderia incrementar as habilidades dos pacientes no sentido de exercer controle sobre sua saúde. O vídeo, um dos instrumentos utilizados na pesquisa, apontou discrepâncias entre a comunicação percebida pelos profissionais de saúde e a real, ocorrida na consulta. Artigo escrito por COUCHMAN (1995), relata experiência com o uso de vídeos como recurso para treinamentos, visando uma melhor comunicação entre profissional e paciente; no caso a interação entre profissionais e pacientes com deficiências de aprendizagem e limitadas habilidades vocais. Por meio do vídeo pôde-se refletir sobre a importância da comunicação não-verbal.

O levantamento de artigos sobre o tema do corpo mostra a importância da questão para a promoção e educação em saúde. Levantam 
pontos a considerar sobre a comunicação em saúde, seja interpessoal ou através da mídia. LUPTON (1993) discute o uso do discurso sobre o risco como controle sobre os corpos. A autora afirma que, ao enfatizar o risco com uma finalidade educativa, por exemplo, ao falar dos riscos atribuídos ao estilo de vida, acaba-se por desviar da compreensão das causas estruturais do processo saúde-doença. Segundo Kroker (1988), citado por LUPTON (1993), o discurso do risco, como é comumente usado em saúde pública, considera o corpo como um local de toxicidade, contaminação e catástrofe, sujeito a e necessitando de um alto grau de vigilância e controle, podendo gerar ansiedade e culpa. LUPTON sugere uma reavaliação desse discurso na saúde.

Outro artigo relata três pesquisas qualitativas realizadas na Escócia, (WATSON, 1996) com indivíduos de 45 a 59 anos, com homens de 30 a 40 anos e com pessoas deficientes físicas, mostrando as percepções sobre o corpo informadas pelo senso comum, assim como suas implicações na promoção em saúde. Para esses autores, a promoção à saúde não presta atenção à experiência vivida dos corpos saudáveis e não saudáveis, não valorizando o poder do nível individual das experiências cotidianas do corpo. Os autores utilizam o conceito de "embodiment", afirmando que a cultura, a estrutura social e o comportamento, não apenas se juntam na articulação das crenças e opiniões sobre saúde e doença, estando também incorporados no ser humano. Os três estudos focalizam os temas do corpo saudável "ideal", a manutenção e cuidado do corpo e as mudanças que nele ocorrem ao longo do tempo. Em duas das pesquisas, as pessoas localizam a saúde no corpo através de critérios relativos a peso, altura, forma, tamanho. Entre os deficientes isso não ocorre. Entre eles o critério de saúde pode não estar baseado na forma do corpo, mas em outras características como, por exemplo, a da sensação individual de ser saudável, apesar de fisicamente poder não aparentar ser. No decorrer do artigo os autores ressaltam a importância - para a área da saúde - do conhecimento e da valorização da percepção de como os indivíduos estão no mundo, através de como seus corpos estão no mundo (o destaque é nosso). Além disso, 
destacam a visão do corpo, não apenas como um campo para a reprodução dos valores e concepções dominantes, mas como um local de resistência e transformação de significados (Crawford,1984 citado por WATSON, 1996).

O levantamento apontou ainda, dois trabalhos sobre a visão do corpo objetivo e do corpo expressivo na medicina alternativa (SCOTT,1998) assim como a noção de espaço e espacialidade na situação de dores crônicas (HONKASALO, 1998).

Como pode ser observado é considerável o número de trabalhos recentes na área da saúde com objetivos de discutir assuntos relacionados à comunicação, seja em termos de avaliação dos produtos comunicativos, discussão de resultados e metodologias de análise, que demonstra o interesse nestes tipos de estudos. Este fato justifica a importância do tema escolhido visando contribuir para o aprofundamento da reflexão 


\section{ASPECTOS TEÓRICOS DO ESTUDO}

\section{Corpo como categoria analítica}

Bryan TURNER, no livro "El cuerpo y la sociedad" (1989) recupera o que existe, na teoria sociológica, sobre o tema do "corpo", abordando alguns pontos relacionados ao surgimento deste como uma questão focalizada na teoria contemporânea. Um deles é o movimento feminista, que procura mostrar que as condições biológicas não determinam a vida social das pessoas, enfatizando aspectos relacionados às diferenças sexuais e de gênero. Outro aspecto discutido é o do desenvolvimento de um mercado do corpo, em que este passa a ser considerado como mercadoria. $\mathrm{Na}$ área específica da saúde ocorreram modificações, por exemplo na medicina, com uma revisão de valores da chamada medicina alternativa. $O$ autor aponta o processo histórico em que se pode identificar a "secularização do corpo em que este deixa de ser o objeto de um discurso sagrado da carne e passa a ser um objeto de um discurso médico, onde o corpo é uma máquina que deve ser controlada através de regimes científicos apropriados. A história desta transição é complexa (....) $\bigcirc$ resultado destas alterações foi a reificação e objetivação do corpo como um objeto de cálculo exato." (TURNER, 1989,p.64) Um último aspecto discutido pelo autor é a crise da modernidade, a partir da qual se rediscute a relação entre corpo, sociedade e natureza. Um dos fatos que surgiu a partir dessa crise é o movimento ecológico, que passa a se preocupar com discussões dessa natureza.

$\mathrm{O}$ autor também discute as abordagens teóricas da sociologia que retardaram ou impediram o aprofundamento do tema, dado que ela trabalha com categorias de atores sociais, classes sociais e Estado, mais amplas do que a do corpo.

Devido a que a macro-sociologia, por exemplo, se interessou pela relação entre as classes sociais e os partidos políticos, entre o Estado e a base econômica da sociedade , e entre a família e a mudança 
econômica, o corpo humano não pode ser situado dentro deste espaço teórico (....) Assim, qualquer intento de dirigir a sociologia na direção de uma teoria do corpo tem que aparecer como uma traição herética, posto que tal ação sugere a um mesmo tempo o biologismo e o individualismo metodológico (TURNER, 1989,p.60).

Apesar dessas limitações, o autor resgata contribuições importantes nas ciências humanas e na teoria sociológica que apontam a sobrevivência do corpo, apesar de sua exclusão teórica (TURNER, 1989,p.61). Analisa, entre outros, teóricos como Foucault e os representantes da fenomenologia, cujas contribuições serão utilizadas no presente estudo. Esses autores são também utilizados na área da antropologia da saúde , cujas propostas serão discutidas adiante. RODRIGUES (1999) aponta também para a importância do corpo na compreensão dos processos históricos e a emergência do indivíduo como protagonista de processos sociais.

O eixo fundamental de nosso raciocínio foi insistir sobre o fato de que uma sociedade só encontra existência nos corpos pulsantes dos seres humanos que a constituem : ela é vísceras, nervos, sentidos, neurônios. A história, dessa maneira, não se concretiza apenas em guerras, decretos, tratados, obras, monumentos ou entronizações: materializa-se também - e talvez até primordialmente - em perfumes, sons,miragens, memórias, carícias, distâncias, ascos, evitações, esquecimentos... Não há outra concretude social: uma sociedade estará nos corpos de seus membros ou não residirá em parte alguma. Concebida a sociedade deste modo, a história sempre será, de algum modo, a história do sensível. E esta nos ensinou, sobretudo, que foi somente em tempos muito recentes que se tornou possível imaginar que o mundo fosse pensável tomando-se como ponto de referência o ser humano isolado e fazendo-se abstração de seus contextos sociais (RODRIGUES,1999, p. 177). 
Na Antropologia a discussão sobre o corpo é um campo muito amplo. Entre as várias abordagens, uma delas, a ser utilizada na presente análise, busca compreender as dimensões do corpo em suas expressões individual, social e política (SCHEPER-HUGHES \& LOCK, 1987). Dessa forma, o corpo não fica reduzido aos aspectos físicos e biológicos. Mesmo quando se pensa na corporalidade, isto é, nas sensações, reconhece-se que estas são físicas e mentais, sendo formadas por condições culturais, sociais e políticas. A abordagem dos três corpos supõe três aproximações teóricas da questão do corpo : a fenomenologia, que aborda o corpo individual e existencial, o estruturalismo e simbolismo, que aborda o corpo social e, finalmente, o pós-estruturalismo, que considera o corpo político (SCHEPERHUGHES \& LOCK, 1987, p.8).

O corpo é experimentado de uma forma individualizada, na medida em que cada indivíduo tem uma existência própria, separada de outros corpos individuais. Essa dimensão individual e existencial, porém, opõe-se à existência social; outra dicotomia, relacionada ao indivíduo, diz respeito à relação corpo-mente. De acordo com RODRIGUES (1999) o processo de individualização ocorre no âmbito de uma forte tendência histórica à fragmentação, que acaba por fazer com que o próprio indivíduo seja depois fragmentado. Segundo SILVA (1999) a configuração dos seres humanos como indivíduos é um processo histórico que atinge a sua culminância na Modernidade. MAUSS (1974) elabora uma análise de grande importância a respeito da história social do conceito de pessoa. Ele analisa como chegamos na modernidade a identificar a pessoa com o "eu". Diz o autor:

(....) eu quero mostrar o quanto recente é a palavra filosófica "eu" , quanto são recentes a "categoria do eu", o culto do "eu" (sua aberração) e quanto é recente o respeito do eu, particularmente do "eu" dos outros ( sua forma normal).(....) Longe de ser a idéia primordial, inata, claramente inscrita no mais profundo do nosso ser desde Adão, eis que ela continua, ainda em nossos dias, lentamente, a edificar-se, a 
esclarecer-se, a especificar-se, a identificar-se com o conhecimento de si, com a consciência psicológica (MAUSS,1974, p. 211/237).

O corpo configura-se também como símbolo das relações entre natureza, cultura e sociedade. "Para os psicanalistas as práticas sociais referem-se as representações inconscientes da experiência do self com o corpo; os antropólogos simbólicos trabalham numa direção oposta, relacionando as experiências do corpo como uma representação da sociedade." (SCHEPER-HUGHES \& LOCK, 1987, p.19) Além disso, freqüentemente utiliza-se idéias sobre o corpo para falar da sociedade. Segundo as autoras, "de particular relevância para os antropólogos médicos são as freqüentes equações simbólicas encontradas entre corpo saudável e sociedade saudável, assim como para o corpo doente e sociedade com problemas de mal-funcionamento." (SCHEPER-HUGHES \& LOCK, 1987, p.20)

Dois autores, citados nesse artigo, são Importantes para a análise da relação entre corpo e sociedade. Um deles, já citado neste estudo, é MAUSS (1974) no capítulo sobre as "Técnicas corporais" . "Entendo por essa palavra as maneiras como os homens, sociedade por sociedade e de maneira tradicional, sabem servir-se de seus corpos (....) Chamo de técnica um ato tradicional eficaz." (p.211/217) O autor aponta que essas técnicas, como o sono, a reprodução, a higiene, etc., diferenciam-se segundo a sociedade e cultura, constituindo hábitos adquiridos. Essa noção é importante porque se pode questionar qual concepção social de corpo leva a tais e quais práticas, deixando-se de considerá-las como simplesmente naturais. É interessante também a visão de que existe uma "grande quantidade de práticas que são ao mesmo tempo técnicas corporais e que são profundas em influências e efeitos biológicos." (MAUSS, 1974, p.226)

$\mathrm{Na}$ mesma obra outro nome que destacamos é o da antropóloga MARY DOUGLAS (1970) que desenvolve um trabalho cujo conceito é o do corpo como um símbolo natural, abordando a idéia de que a concepção social do corpo estabelece os limites da percepção do corpo físico. "A 
experiência física do corpo, sempre modificada pelas categorias sociais através das quais ele é conhecido, mantém uma visão particular da sociedade." (MARY DOUGLAS,1970,p.65)

Em outro livro, BERGER (1978) aborda a dialética que existe entre os fatores biológicos do organismo humano e a sociedade - que preexiste a cada indivíduo-, apontando que se estabelece uma relação mútua entre os dois pólos, ou seja, que a sociedade estabelece limites para o organismo, assim como o organismo estabelece limites para a sociedade. "Na dialética entre a natureza e o mundo socialmente construído, o organismo se transforma. Nesta mesma dialética o homem produz a realidade e com isso se produz a si mesmo."(p.241)

O antropólogo GEERTZ (1978) refere-se ao comportamento humano , considerando o corpo individual em relação ao social:

Entre o que o nosso corpo nos diz e o que devemos saber a fim de funcionar, há um vácuo que nós mesmos devemos preencher, e nós o preenchemos com a informação (ou desinformação) fornecida pela nossa cultura. A fronteira, entre o que é controlado de forma inata e o que é controlado culturalmente no comportamento humano, é extremamente mal-definida e vacilante. (...) Quase todo comportamento humano complexo representa, sem dúvida, o resultado interativo e não-aditivo dos dois (GEERTZ, 1978,p.62).

Com relação ao corpo político, - o terceiro corpo citado por SCHEPER-HUGHES \& LOCK (1987) - este é visto como um artefato do controle político e social. Segundo as autoras, as diferentes culturas geram uma "domesticação do corpo individual em conformidade com as necessidades da ordem política e social." (p.26) O uso da tortura, o controle exercido sobre os corpos pela justiça criminal, pela medicina, pela psiquiatria, criando categorias de normalidade, são exemplos do uso do conhecimento e do poder sobre os corpos. Em várias áreas da vida, esse controle ocorre, tanto no mundo do trabalho quanto no da sexualidade. 
Um teórico citado pelas autoras é Foucault. Esse autor desenvolve uma análise do processo que leva à criação de corpos normais e dóceis, mostrando o papel da medicina nesse processo. Também TURNER (1989, p.62) chama a atenção para o fato de que a idéia da historicidade do corpo é uma das contribuições primordiais do enfoque focaultiano que torna a história do homem num objeto para a ciência. Quando pensamos no desenvolvimento do conhecimento sobre o corpo e nas chamadas "técnicas corporais", percebemos que as intervenções sobre o corpo, assim como o uso do conhecimento e do poder sobre ele tem também uma história, não é algo imutável.

Outro autor normalmente citado, quando se aborda o tema do corpo, é Merlau-Ponty, um dos representantes da fenomenologia. Ele trata o tema como uma questão central na percepção do mundo. O corpo é considerado como nosso ponto de vista sobre o mundo, como o local onde começa a percepção. "O corpo é o veículo do ser no mundo, e ter um corpo é, para uma pessoa viva, juntar-se a um meio definido, confundir-se com alguns projetos e engajar-se continuamente neles." (MERLEAU-PONTY, 1971,p.94) Segundo TURNER (1989,p.82-83) para Merleau-Ponty o corpo nunca é somente um objeto físico, mas uma corporificação da consciência e, dessa forma, pleno de significação simbólica. Na teoria a respeito dos três corpos, a que nos referimos antes, a fenomenologia é ressaltada por expressar a importância do corpo individual ou existencial. Há, entretanto, críticas à fenomenologia que a apontam oferecendo uma explicação individualista que não dá conta, por exemplo, de questões a respeito do controle do corpo , questões relacionadas à estrutura social e regulação institucional (TURNER, 1989,p.88). Este autor ressalta que o problema do corpo não é simplesmente uma questão fenomenológica, mas também - e além disto um lugar teórico para os debates em torno do poder, a ideologia e a economia (p.89).Outros autores, como CSORDAS (1990), porém, defendem que a abordagem fenomenológica inclui a dimensão social. Do ponto de vista da relação entre a percepção individual e seus condicionamentos culturais e sociais, pode-se depreender que, ao dizer que a percepção 
começa nos corpos e entendendo-se que o corpo não se reduz ao físico, para Merleau -Ponty a dualidade sujeito x sociedade é resolvida pela visão de que o social existe antes de qualquer objetificação e por isso não se constitui num objeto separado de nós, sujeitos. "Nós precisamos retornar ao social com o qual estamos em contato pelo simples fato de existirmos e o qual carregamos inseparavelmente conosco antes de qualquer objetificação." (Merleau-Ponty,1962 citado por CSORDAS,1990,p.10) O corpo carrega nosso passado e traz a existência biológica para o nível pessoal, sendo protagonista de uma história de vida extremamente imbricada em suas bases sócio-culturais.

Dessa forma, ao constatarmos que o corpo e as emoções carregam significados individuais, sociais e culturais, pode-se, através deles, iniciar um processo de reflexão. Nesse sentido, os recursos audiovisuais, que lidam basicamente com o afetivo e com a percepção , são extremamente ricos para a interpretação dos significados da ação e da vida humana. Porém a utilização destes recursos só faz sentido a partir de uma visão de educação que valorize o desenvolvimento de capacidades e potencialidades humanas que não apenas a racional e a lógica.

Algumas colocações de TURNER são significativas para o presente estudo, principalmente quando discorre sobre os paradoxos do corpo. São justamente estes paradoxos que nos levaram ao desejo de analisar os significados do corpo nos vídeos. Em vários deles observam-se aspectos que podem revelar pistas para a interpretação mais aprofundada dos programas selecionados. Estes paradoxos, por sua vez, remetem a algumas oposições complementares que podem ser observadas como, por exemplo, a relação entre o biológico e o social, entre o indivíduo e a sociedade, entre as partes do corpo e o todo (por exemplo, entre o corpo e a mente) e entre a natureza e a cultura.

Temos corpos, mas somos também em um sentido específico, corpos; nossa corporalidade é uma condição necessária de nossa identificação social (....) Nossos corpos são um entorno natural, não obstante 
estarem socialmente constituídos (....) O corpo é um organismo material, mas também uma metáfora (TURNER, 1989,p.32).

Esses paradoxos são levantados pelo autor, dando-nos a idéia da multiplicidade de valores e sentidos atribuídos ao corpo. "O corpo é a um mesmo tempo a coisa mais sólida, mais elusiva, ilusória, concreta, metafórica, sempre presente e sempre distante: um lugar, um instrumento, um entorno, uma singularidade e uma multiplicidade." (TURNER, 1989,p.32)

BERGER (1978) ao abordar o caráter social da autoprodução do homem discute também a questão do corpo, afirmando que ao mesmo tempo em que o homem é um corpo, ele também tem um corpo, diferenciando-o de outros seres animais. "Isto é, o homem experimenta-se a si próprio como uma identidade que não é idêntica a seu corpo, mas que, pelo contrário, tem esse corpo ao seu dispor."(p.74) Estas afirmações trazem conseqüências para a análise das relações entre indivíduo e sociedade, entre o biológico e o social e entre a natureza e a cultura, colaborando para explicitar o caráter de oposições que estas relações possuem, caracterizando-as, ao mesmo tempo, como relações complementares. "A humanidade específica do homem e sua socialidade estão inextricavelmente entrelaçadas." (p.75)

STRATHERN (1996) ao discorrer sobre alguns pontos relevantes sobre o dualismo cartesiano mente/corpo elenca alguns componentes do naturalismo que é uma visão de que nós somos partes da natureza, visão esta que passa a existir com o lluminismo. Um destes componentes nos diz que a parte é independente e primordial sobre o todo. Esta é a premissa básica do atomismo contra o holismo. ( 1145$) \mathrm{O}$ autor coloca também que historicamente " (....) o tratamento do corpo como objeto foi dirigido principalmente pela anatomia, pela invenção da anestesia, e pelas práticas manipulativas derivadas da anatomia e da anestesia, a cirurgia." (p146) Assim à dicotomia parte $\mathrm{x}$ todo pode se associar a visão do corpo como um objeto, cujos órgãos são passíveis de intervenções, levando a um distanciamento do todo, ou seja, do indivíduo e da cultura. 
CANGUILHEM (1992) por outro lado, analisa a construção da noção do corpo como máquina. Como ele coloca, uma herança importante, na constituição da visão do corpo como composto por partes, é a visão de Descartes, na qual o corpo é visto como máquina e pela qual afirma-se que há um pouco da máquina em cada aspecto da vida. Em toda máquina como no corpo - o movimento é uma função da forma como as partes interagem e das operações mecânicas da unidade toda ; todo movimento da máquina é geométrico e mensurável. Decorrente desta visão a doença é encarada como um problema a ser reparado, e desta forma o corpo é visto como uma "máquina" doente na qual se trava uma batalha; esta postura reflete-se, por exemplo, na utilização da metáfora da guerra como recurso para explicar este processo.

FOUCAULT ( 1984 ), ao referir-se ao processo de espacialização da doença, aponta que :

A doença(....) aparece através do corpo. Neste, ela encontra um espaço cuja configuração é inteiramente diferente: espaço dos volumes e das massas (....). O que faz o "corpo" essencial da doença se comunicar com o corpo real do doente não são, portanto, nem os pontos de localização, nem os efeitos da duração; é, antes a qualidade (....) A percepção da doença no doente supõe, portanto, um olhar qualitativo (FOUCAULT,1984, p.9/13).

Como um paradoxo, porém, para poder se conhecer a doença, busca-se subtrair o indivíduo com suas qualidades singulares vendo-o como um elemento negativo. "Mas a doença nunca pode se dar fora de um temperamento, de suas qualidades, de sua vivacidade ou de seu peso; e mesmo que ela mantenha sua fisionomia de conjunto, seus traços sempre recebem, nos detalhes, colorações singulares." (FOUCAULT ,1984,p14)

TAUSSIG (1980) afirma que sinais e sintomas são tanto fatos sociais quanto são fatos físicos e biológicos; ao se negar as relações humanas incorporadas nos sinais e sintomas mistifica-se estas relações e reproduz-se 
a ideologia da reificação que serve à manutenção da ordem social ,em detrimento da cura. Buscando argumentos para reverter esta situação STRATHERN (1996) diz que o corpo físico ou biológico carrega poucos significados ao menos que ele seja visto através de outros aspectos, daí o sentido do conceito de "embodiment" que ele utiliza . O que é incorporado é sempre um conjunto de significados, valores, tendências e orientações que derivam da esfera sociocultural (p.197).

BERGER (1978) também chama a atenção para a questão da reificação que ocorre tanto com relação à ordem institucional e aos papéis sociais quanto com relação à identidade, tanto a do indivíduo quanto a dos outros. Este fato é um problema que gera um paradoxo, na medida em que perde-se a conexão entre criação humana e o mundo objetivo - e seus significados-, fazendo com que este último seja visto como produto da natureza das coisas e não como derivado da ação social humana (122-126).

A reificação traz conseqüências para a compreensão do corpo no mundo, na medida em que ele passa a ser visto como algo apenas do reino da "natureza", desconectado de seus significados culturais e sociais. Correse o risco ainda de perder de vista a noção de que estes significados, construídos pelos próprios homens em sociedade, formam e transformam o próprio corpo dos indivíduos.

Alguns autores buscam novas propostas sobre como lidar com as oposições, como, por exemplo, entre a natureza e a cultura, a parte e o todo, o sujeito e o objeto, e entre as dimensões individuais, sociais e políticas. CSORDAS (1990) ao utilizar-se da categoria de "embodiment" coloca um postulado metodológico no qual o corpo não deva ser um objeto a ser estudado em relação com a cultura, mas ser considerado como um sujeito da cultura ou, em outras palavras, como um campo existencial da cultura (o destaque é nosso; p128).

Refletir sobre os conflitos e dicotomias vivenciadas pelos indivíduos em seus corpos - na expressão de seus corpos - questionar a fragmentação sofrida, é um passo importante para sua reintegração. Acredito que esta possa ser uma reflexão interessante numa perspectiva de promoção da 
saúde que valorize tanto os aspectos coletivos como individuais. SCHEPERHUGHES \& LOCK (1987) afirmam que esta unidade pode ser buscada através da emoção: "como as emoções implicam em sentimentos , aspectos cognitivos, moralidade pública, ideologia cultural, nós sugerimos que elas propiciam um importante elo perdido, capaz de integrar corpo e mente, indivíduo, sociedade e corpo político." (p28) O momento em que se assiste a um filme ou um vídeo, quando ele busca atingir as emoções, é uma ocasião em que se pode confrontar as imagens apresentadas com aquelas imagens mentais conformadas pela nossa cultura. Como diz RODRIGUES(1999) existem perspectivas corporais diferentes, em sociedades não ocidentais , e às vezes em momentos que vivenciamos mesmo em nossa cultura. Segundo o autor, nestas concepções o corpo:

(....) remete sempre a si e aos outros corpos ao mesmo tempo, sendo essencialmente no plural. Não é de modo algum isolável daquele a quem atribui um rosto e de quem é o único indício de existência. Também não é separável daqueles com quem coexiste (....) Corpo fluido, que se desfaz ao mesmo tempo em que a vida o constitui. E que se constitui ao mesmo tempo em que a vida o desfaz. Tal corpo não vive. Convive (RODRIGUES, 1999,p. 191/192). 


\section{Comunicação}

Uma das teorias utilizadas neste estudo para descrição do produto comunicativo foi o modelo elaborado pelo lingüista JAKOBSON (1969). Esse autor analisa as funções da linguagem verbal. Apesar dos produtos audiovisuais utilizarem outras linguagens além da verbal, utilizamos esse referencial para buscar compreender quais as funções predominantes que os vídeos possuem. Seus realizadores podem ter uma preocupação maior em reforçar o discurso de quem emite a mensagem, centrar na própria mensagem e em seu contexto, ou ainda buscar capturar o interesse do espectador. Estas opções fazem com que o produto adquira diferentes funções em termos comunicativos. Desta forma a extensão do estudo das funções da linguagem para os produtos audiovisuais foi realizado somente com a finalidade de propiciar uma compreensão de sua intencionalidade. Apresentam-se a seguir as funções da linguagem:

- Referencial : denotativa ou cognitiva; a linguagem orienta-se para o contexto da mensagem; como exemplo, tem-se o discurso científico .

- Emotiva: a atitude do sujeito falante frente ao objeto da mensagem; " visa a uma expressão direta da atitude de quem fala em relação àquilo que está falando" (p.123); por exemplo: discurso amoroso.

- Conativa : o objetivo é conseguir uma reação do destinatário da mensagem; como exemplo tem-se a propaganda publicitária na qual a comunicação é imperativa.

- Fática : visa a captar e manter a atenção, prolongar ou interromper a comunicação; no texto essa é a função exercida pela pontuação.

- Metalingüística: o discurso focaliza o código de comunicação, fornecendo informações sobre ele.

- Poética : visa a produção estética , com um enfoque na configuração da própria mensagem; não está limitada somente à poesia.

Por outro lado os recursos audiovisuais, por trabalharem com imagens, possuem um poder de comunicação que precisa ser conhecido para ser utilizado. GIACOMANTONIO (1981) distingue três níveis de 
atenção dos indivíduos com relação à imagem: o instintivo depende basicamente da percepção de cores, formas, expressões, constituindo elementos emotivos por excelência; o descritivo capta a descrição de objetos, ambientes e individualização do assunto; finalmente o simbólico supõe um nível de abstração da leitura da imagem

Neste trabalho estar-se-á utilizando o termo "linguagem audiovisual", que diz respeito aos elementos e recursos de expressão articulados de forma a dar sentido a uma mensagem. Os elementos considerados são os seguintes:

- roteiro: a partir de uma idéia e da forma com que se pretende abordá-la e trabalhá-la constrói-se uma estrutura; é a concepção do trabalho que se pretende realizar, no qual estão articulados a imagem e o áudio (músicas e falas), assim como a forma com que os mesmos irão aparecer (ex: locução em "off", plano geral de uma escola, etc.)

- movimento de câmera: permite a realização de movimentos de aproximação e distanciamento do objeto filmado (BETTON,1987), visões panorâmicas (quando a câmera desenvolve um movimento circular), acompanhamento da cena (travelling), quando a câmera descreve um movimento, etc . De acordo com COMPARATO (1983)a forma com que trabalhamos os movimento de câmera revelam detalhes que não nos são revelados na vida cotidiana (p.150). Segundo BETTON (1987) "um movimento de câmera não tem uma função unicamente descritiva. Pode também ter uma função psicológica ou dramática, particularmente ao exprimir ou materializar a tensão mental de um personagem. Finalmente, pode ter também uma função "rítmica"(.....)." (p.36-37) Os movimentos de câmera conduzem o olhar do espectador precisamente para onde se deseja, contribuindo, juntamente com os recursos de edição ou montagem, para criar o clima do programa ou filme. Movimentos de câmera rápidos geram um clima agitado e inquieto, muito utilizados em programas voltados para público jovem.

- enquadramento: informa $\mathrm{o}$ centro de interesse na imagem (LONGHI,1987,p.47). Diz respeito aos planos e ângulos de tomada. De 
acordo com PASSARELLI (1999,p 276) com relação aos planos temos: o geral, no qual nenhum elemento possui destaque, mostra-se todo o espaço da ação; o médio, principalmente em interiores, mostra um conjunto de elementos (figuras humanas e cenário) envolvidos na ação; o plano americano em que figuras humanas são mostradas até a cintura; o primeiro plano, ou close, em que temos o detalhe de um corpo ou objeto e o primeiríssimo plano onde temos um maior detalhamento. O close, segundo outro autor, "possui um grande valor expressivo e valoriza o assunto, possibilitando captar os matizes." (GIACOMANTONIO, 1981) Os ângulos ou a perspectiva segundo a qual a câmera "olha" para o objeto filmado são: o normal, no qual a câmera é mantida horizontalmente na altura da pessoa; o de cima para baixo (câmera alta), cujo efeito criado é de esmagamento, sufocamento, sujeição, e o de baixo para cima (câmera baixa), cujo efeito "evoca a superioridade, o poder, o triunfo, o orgulho, a majestade, ou senão a tragédia e o pavor." (BETTON,1987,p.34-35) O enquadramento - ou o desenquadramento - traduz o ponto de vista, seja ele entendido como local a partir do qual uma cena é olhada ou como uma forma específica de se encarar e considerar uma questão ou acontecimento (AUMONT ,1993).

- montagem ou edição: a montagem é o procedimento utilizado no cinema, enquanto no vídeo a técnica é a de edição, realizada eletronicamente. Pode-se alterar as cenas, realizando-se inserções, efeitos, fusões, etc. Os recursos existentes permitem que se altere o tempo real; pode-se acelerar ou retardar o movimento, gerando efeitos cômicos ou de uma maior densidade psicológica.; pode-se intervir, também, concentrandose ou dilatando-se o tempo e, entre outras coisas, fundindo-se duas temporalidades como nos chamados "flashbacks" (BETTON,1987).

- sonoplastia: compreende o material sonoro, incluindo músicas e os ruídos; podem-se realizar combinações entre o som e a imagem que sejam complementares, redundantes, contraditórias ou em contraponto."O som e a imagem são, alternadamente, fonte de 
informações específicas que remetem umas às outras" (BETTON,1987,p.40).

Alguns autores citam ainda outros elementos de linguagem como o cenário, a iluminação, a cor, a profundidade de campo - importante no cinema, mas não na televisão- e a representação dos atores.

MACHADO (1993), referindo-se ao vídeo, coloca questões específicas a respeito do tipo de discurso criado:

Sabemos pelo simples exame retrospectivo da história desse meio de expressão, que o vídeo é um sistema híbrido, ele opera com códigos significantes distintos, parte importados do teatro, da literatura, do rádio e mais modernamente da computação gráfica (...) $O$ discurso videográfico é impuro por natureza, ele processa formas de expressão colocadas em circulação por outros meios, atribuindo-lhes novos valores, e a sua "especificidade", se houver, está, sobretudo na solução peculiar que ele dá ao problema da síntese de todas essas contribuições (MACHADO,1993, p.6).

Em conseqüência disso e das características tecnológicas do meio, pode-se identificar algumas tendências na linguagem específica do vídeo. A primeira é o uso de primeiros planos ou "closes", mais adequado em função da baixa definição da imagem que dificulta a compreensão de imagens com excesso de informações e detalhamentos. "Multidões em plano geral são motivos pouco adequados ao vídeo, assim como são inadequados os cenários amplos e decorações muito minuciosas, pois todos esses motivos se reduzem a manchas disformes quando inseridos na tela pequena." (MACHADO, 1993,p.7) Segundo o autor outra característica é a de que o roteiro e a edição busquem a justaposição de planos singelos, visando a articulação de sentido através do uso de metáforas. Uma terceira característica é a de que, em função das condições de recepção- ou seja, a de que o vídeo é assistido em meio a outras atividades- sua informação deve ser do tipo "recorrente, circular, reiterando idéias e sensações a cada 
novo plano, ou então quando ela assume a dispersão, organizando a mensagem em painéis fragmentários e híbridos, como na técnica da collage." (MACHADO, 1993,p.10)

A abordagem acima coloca-se na linha de investigação dos autores que estudam as relações entre tecnologia e linguagem. A reflexão sobre a relação entre a linguagem e as características tecnológicas dos vários meios de comunicação (televisão, cinema, vídeo) são úteis como pontos de referência para a análise dos limites de cada um destes meios e das possibilidades de exploração de suas capacidades.

A videoteca do CEFOR possui materiais com características mais próximas da linguagem do cinema, e outros com linguagem televisual. Alguns são programas dirigidos a um público específico, diferente de muitas das produções da televisão que se destinam a um público muito mais amplo. As condições de recepção do vídeo nas situações de ensinoaprendizagem, porém, colocam-se como um meio termo entre as condições de recepção da televisão e do cinema. Assiste-se ao vídeo numa sala clara, porém, a situação é diferente daquela quando se assiste televisão em casa, pois não há situações perturbando a atenção. Há condições para maior concentração e interiorização, possibilitando que se acione o que MORIN (1983) denomina de mecanismo de projeção-identificação, mecanismo desencadeado nas exibições cinematográficas. Este autor explicita este mecanismo, esclarecendo como nossas necessidades, aspirações e desejos projetam-se sobre situações e personagens apresentados na tela, fazendo com que a participação do espectador se interiorize, absorvendo o mundo representado, incorporando o meio ambiente (cenário, personagens) integrando-os afetivamente, originando o que ele denomina de "participação afetiva" (MORIN, 1983, p.151). Tais afirmações podem ser acrescidas pelas considerações de $\operatorname{AUMONT}(1995$, p.110) que, ao citar Metz, ressalta que o cinema apresenta um fator positivo que é a sua imaterialidade, a qual favorece a participação afetiva; esta, por sua vez, faz com que o espectador esteja mais investido psicologicamente na imagem. LANDOWSKI (1996) 
aponta que a relação corporal do espectador com a obra colabora na apreensão do sentido das mensagens:

(....)certa emoção ou determinada sensação sendo experimentada e figurada pelo outro no seu corpo, ao encontrar reexperimentada pelo e no corpo do próprio espectador, o efeito de contágio não se distingue da apreensão de uma significação ; nesse gênero de transmissão corpo a corpo, o que imediatamente "se sente "é o "sentido" mesmo. O sentido é sentido. (LANDOWSKI,1996,p39).

As situações de recepção dos vídeos fogem um pouco a situação do cinema, comprometendo provavelmente o investimento emocional do espectador; porém não se pode descartar a possibilidade de que este seja um mecanismo que atue, mesmo que de forma mais superficial. $\mathrm{O}$ fato de a exibição dar-se na tela pequena de um aparelho de televisão pode também dificultar esse processo. É preciso considerar, por outro lado, que uma boa parte dos materiais é construída com códigos provenientes da linguagem televisual, condicionando também a sua recepção. Nesse caso deve-se atentar para os processos - analisados por MACHADO (1988) - que ocorrem na recepção dos sistemas de alta e baixa definição, como o cinema e a televisão:

(....) isso significa que, nos processos figurativos de alta definição, a articulação do sistema se dá à custa da acomodação e do anestesiamento do decodificador, que já recebe a informação pronta e carregada de módulos de ordem, aos quais é impossível resistir (....) Inversamente, nos processos de baixa definição, o espectador coloca sua energia a serviço da decodificação, o que significa atividade e participação (....) A verdade é que a imagem de vídeo, pequena, estilhaçada, sem profundidade, pouco realista e de efeito ilusionista extremamente precário, não pode fascinar o espectador a ponto de fazêlo perder a vigilância sobre suas próprias sensações; pelo 
contrário, a precariedade dos meios serve-lhe de distanciamento crítico e de estímulo para a intervenção no universo simbólico. (MACHADO, 1988,p.61$62)$.

Esses são alguns dos fatores que influenciam as questões relativas à percepção e devem ser levados em conta para se avaliar as possibilidades de trabalho com os conteúdos percebidos. Há dúvidas, entretanto, quanto à possibilidade de atividade participativa na decodificação de programas com um padrão televisual muito tradicional, ou seja, quando as reportagens e entrevistas são estruturadas, por exemplo, da forma que vemos nos vários telejornais.

É importante que se faça uma ressalva, a de que este estudo está baseado em observações do material produzido, orientadas pelas leituras dos teóricos selecionados, ou seja , é uma análise centrada no produto, que busca interpretar seus significados sociais e culturais, especificamente com relação ao corpo. O objetivo deste trabalho não foi o de realizar um estudo de recepção.

No campo da comunicação são vários os teóricos que analisam a problemática que envolve a imagem. Dentre eles utilizou-se do trabalho de AUMONT (1993) do qual selecionaram-se algumas abordagens úteis ao estudo.

Ao analisar a representação do corpo no vídeo, o presente estudo lida basicamente com a função simbólica da imagem, que, juntamente com a função representativa, explicam as formas de observá-la. Baseado em Gombrich, AUMONT (1993) refere-se a uma dicotomia entre reconhecimento e rememoração. O reconhecimento dá-se pela função representativa da imagem, que permite reconhecer as características visuais do mundo real e as imagens, propiciada pela relação de semelhança num maior ou menor grau com a realidade visível. A rememoração permite que, através da função simbólica, o ato de ver seja o de " comparar o que esperamos à mensagem que nosso aparelho visual recebe." ( p.87) Desta forma, ao fazer intervir seu conhecimento prévio, o espectador da imagem 
supre o não representado, as lacunas da representação, fazendo com que a imagem seja, tanto do ponto de vista de seu autor, quanto de seu espectador, um fenômeno também ligado à imaginação (AUMONT,1993, p.88-89). O olhar sobre uma imagem é modificado, portanto, pelas informações que o indivíduo tem, fazendo com que a trajetória do olhar deixe de se encaminhar simplesmente àquelas áreas com mais informação, que permitem reconhecer as imagens numa segunda apresentação, para ser guiado por outras ordens (AUMONT,1993,p.61).

SANTAELLA \& NÖTH (1997) analisam a questão da imagem através da abordagem semiótica. Os autores colocam questões comuns, tais como a imagem como percepção e imaginação e a percepção da forma como um processo não só de recepção, mas de coordenação entre o percebido e as formas internalizadas(p.45). Apontam para questões importantes como a influência da linguagem verbal sobre a imagem, o papel da contextualização com outras imagens, a função dos sons, da música, etc:

A concepção defendida de que a mensagem imagética depende do comentário textual tem sua fundamentação na abertura semiótica peculiar à mensagem visual. A abertura interpretativa da imagem é modificada, especificada, mas também generalizada pelas mensagens do contexto imagético. O contexto mais importante da imagem é a linguagem verbal. Porém, outras imagens e mídias, como por exemplo a música, são também contextos que podem modificar a mensagem da imagem $(. . ..) \circ$ contexto da imagem não precisa ser necessariamente verbal. Imagens podem funcionar como contextos de imagens. Entretanto, num sentido semiótico mais geral, no qual as imagens são um dos tipos possíveis, não há signo sem contexto, visto que a mera existência de um signo já evidencia o seu contexto (SANTAELLA \& NÖTH, 1997, p. 53/57).

Os autores explicam como a imagem nos atinge, colocando algo de certa forma semelhante a AUMONT. Afirmam que, sem memória e 
antecipação, nenhum reconhecimento e identificação são possiveis: "onde quer que o ser humano ponha seu olhar, esse ato estará irremediavelmente impregnado de temporalidade." (SANTAELLA \& NÖTH, 1997, p.87). Esse tempo, porém é, além de um tempo biológico e fisiológico, um tempo histórico e cultural.

Dentre os materiais selecionados para análise neste estudo, encontram-se três vídeos que podem ser considerados como sendo vídeos populares. O termo vídeo popular insere-se na chamada comunicação popular, configurando uma produção com uma formatação específica por opção dos realizadores, em função da realidade social vivenciada. De acordo com SANTORO (1989):

A partir do início da década de 80 , com o relativo abrandamento das restrições políticas por parte do Estado, há uma intensificação das manifestações de comunicação ao nível das bases sociais, isto é, da comunicação popular, principalmente por meio de jornais, boletins, folhetos, programas de rádio por alto-falantes, programas de vídeo, etc (....) O vídeo chega aos grupos e movimentos populares como mais um componente de luta e, por suas características técnicas, adapta-se bem a projetos de comunicação popular que têm os diferentes grupos sociais como público-alvo, prestando-se desde a simples exibição de programas pré-gravados até programas originais (....) Tudo isso é, para nós, o vídeo popular. Uma definição abrangente, que tem como referência primordial a prática do uso do vídeo pelos movimentos populares, o volume dessa produção, o seu teor, os grupos que são responsáveis por ela e a exibição de programas comprometidos com a realidade social (SANTORO, 1989, p.59-61).

A respeito da experiência de vídeo independente no Brasil, MACHADO (1996) coloca várias questões importantes ao procurar ver as singularidades dessas experiências em relação às da televisão comercial. As inovações e rupturas na estrutura da linguagem dão-se por ex. com relação às 
entrevistas, momento em que se dá a intervenção popular ; nas empresas televisuais a intervenção costuma ser breve e lacônica, para apenas endossar o que o apresentador afirmou. Nestas experiências, porém, busca-se uma outra abordagem:

Uma forma de perfurar todos estes esquemas viciados é reinventando inteiramente a instituição da entrevista. O Olhar Eletrônico* enfrentou este desafio através de suas perguntas "impossíveis" e inesperadas, que estimulam respostas pouco convencionais e barram qualquer recurso ao repertório de chavões (MACHADO, 1996, p267).

Os vídeos "populares" analisados neste estudo buscam também fugir ao que convencionalmente se utiliza nas produções de televisão comercial, apesar de utilizarem-se de recursos de linguagem semelhantes.

Das produções selecionadas, exceto uma (Divina Previdência), todas poderiam ser classificadas como vídeos educativos. Esta definição é, porém um pouco vaga e imprecisa. Estudo realizado por SIQUEIRA \& VARGAS (1999) aponta que “(....) é precisamente o caráter de intervenção, característico das práticas e ações de saúde configuradas pelos movimentos pela melhoria da saúde, que enquadra a produção em questão como sendo de caráter educativo." (SIQUEIRA \& VARGAS ,1999,p.71) Esse estudo, porém não se atém aos vídeos em si, mas analisa como um grupo de profissionais de saúde interpreta os discursos apresentados pelas imagens.

O vídeo "Divina Previdência" que, em princípio não se encaixaria nesta definição, é um material de ficção, que pode ser utilizado em ações educativas, principalmente para sensibilização durante atividades de treinamento. Coloca-se aqui uma outra questão : o "educativo" não se refere também ao processo de utilização e não, simplesmente, à formatação do próprio material ou ao seu conteúdo? Pode-se, por exemplo, utilizar uma novela, uma campanha publicitária, como material educativo. Por outro lado, um vídeo concebido como educativo, pode ter uma formatação tão rígida e

\footnotetext{
* Olhar Eletrônico : produtora de vídeos de São Paulo
} 
estereotipada que não permita uma utilização educativa. Muitas vezes os chamados "vídeos educativos" preocupam-se em descrever e demonstrar certos fatos, seguindo um esquema tradicional de aula, sem considerar as características do meio e descuidando-se do conceito de participação da população-alvo. Isso deriva da dificuldade de transpor os conceitos científicos para a linguagem audiovisual. Tal fato ocorre em função da preocupação de que as informações veiculadas sejam cientificamente corretas e que a função da linguagem seja prioritariamente referencial. Isso acaba por fazer com que os realizadores se apeguem a formas conhecidas e às vezes desgastadas. Segundo MACHADO (1988) :

Programas dissertativos ou narrativos que consistem na ilustração de um tema concorrem para eliminar a intervenção do espectador, impondo-Ihe a evidência de uma demonstração em vez do processo de reconhecimento e, nesse sentido, participam dos interesses de centralização de que o veículo é vítima (MACHADO, 1988,p.94).

Em artigo sobre comunicação para promoção da saúde, DON PALMER (1992) menciona que os programas televisivos sobre saúde, por buscarem transmitir comportamentos e atitudes corretas e saudáveis de uma forma excessivamente rígida, correm o risco de se tornarem algo previsível ao qual faltam drama, diversão e alegria. Acreditamos que, se não houver uma atenção a estas questões, este risco também pode comprometer os vídeos educativos. É importante ter em mente que o vídeo não precisa dizer tudo, existem conteúdos que podem ser abordados após a sua exibição, visando complementar o processo educativo.

Há vídeos em que se observa uma função estética (ou poética), o que não compromete em nada seu uso. O fato de não ser um vídeo de natureza educativa e informativa não impede que seja utilizado em circunstâncias ligadas à Educação e à Promoção em saúde. Ao discorrer sobre o componente poético e estético em obras literárias, BALOGH (1996) utiliza o conceito de Jakobson sobre a função poética da linguagem, ressaltando as 
características de ambigüidade e plurissignificação. Traçando um paralelo com as produções audiovisuais, pode-se afirmar que os materiais criados com uma preocupação e um objetivo estéticos - mesmo que não seja o principal - possuem uma riqueza maior justamente por essas características, podendo propiciar uma gama maior de leituras e interpretações. Quando o vídeo é construído buscando uma forma mais equilibrada, mais harmônica, ou seja, com uma preocupação com a beleza, pode propiciar ao público uma fruição que vai além do interesse pelo científico.

Uma outra questão importante no campo da comunicação que traz conseqüências e configura alguns limites do estudo diz respeito à dificuldade da transposição do plano de expressão, que é o das imagens, para o plano de expressão da análise, que é o da escrita. Segundo Peñuela Canizal citado por BALOGH (1996): "(....) no que tange ao cinema, a semiótica do texto cinematográfico deverá vencer uma difícil barreira : a não-iconicidade entre o plano de expressão da metalinguagem do analista e o plano de expressão da linguagem-objeto." (p31) E como ressalta METZ (1974) “(....) a semiologia do visual, não é essencialmente, uma atividade visual. " (p.17) Uma das formas utilizadas neste estudo para lidar com esta questão foi anexar fotos de segmentos dos vídeos, chamados de "frames", que seriam os equivalentes dos fotogramas no cinema. 


\section{Comunicação, Educação e Promoção à saúde: algumas considerações}

$\mathrm{Na}$ área de saúde, mais especificamente na promoção e na educação, pressupõe-se a utilização dos audiovisuais como recursos auxiliares nas ações educativas. A definição da promoção à saúde como "uma combinação de apoios educacionais e ambientais que visam atingir ações e condições de vida conducentes à saúde" (CANDEIAS, 1997) e a definição de educação em saúde como "quaisquer experiências de aprendizagem, delineadas com vistas a facilitar ações voluntárias conducentes à saúde" (CANDEIAS, 1997), apontam os recursos de comunicação como suportes às situações de ensino-aprendizagem.

Quando se pensa nos meios de comunicação de massa e no seu papel na promoção à saúde, é preciso considerar, entretanto, que o efeito educativo desses meios é, muitas vezes, não intencional e assistemático . Isso se observa em conteúdos de saúde veiculados nas novelas, propagandas, programas de entrevistas, etc. Esse tipo de comunicação é unidirecional, sem um feed-back sobre o impacto do processo, diferenciando-se fundamentalmente da comunicação interpessoal. Levandose em conta essas limitações, recomenda-se que, ao elaborar materiais educativos, os especialistas tenham um conhecimento das características da audiência, de forma mais segmentada possível, para que possam adequar o texto, as imagens e os cenários, à realidade desse público.

Com essa finalidade realizam-se pesquisas e testes. Quanto mais amplo e diversificado for o público a ser atingido, menos especificidade deverá ter a mensagem, pois para atingir um maior número de pessoas deve-se ter uma mensagem com um maior nível de generalização. Por outro lado, quanto mais especificidade puder ter a mensagem, maior será o efeito em termos qualitativos. Os meios de comunicação de massa podem incrementar conhecimentos e gerar uma resposta rápida e emocional. Além disso, podem contribuir para propiciar mudanças societárias, apesar de não garantí-las. 
Um aspecto importante abordado por alguns autores é de que estes produtos são mais eficazes quando fazem parte de uma campanha integrada a outras formas de comunicação. A propósito, pode-se referir uma pesquisa, realizada na Universidade de Stanford em 1972 a respeito de prevenção de doenças cardíacas (NAIDOO E WILLS, 1994,p. 87). O estudo, de natureza experimental, realizou-se em três comunidades. Em uma delas foram utilizadas as mais variadas estratégias de comunicação, incluindo uso de televisão, rádio, jornal, posters em ônibus, lojas, locais de trabalho, além do envio de folhetos para as residências; na outra comunidade, além destes recursos, também se utilizou a educação em saúde individualizada. Uma terceira comunidade foi utilizada como controle. Os resultados mostraram que houve um aumento nos níveis de conhecimento com relação aos fatores de risco nos dois primeiros grupos, mas as mudanças comportamentais, referentes aos hábitos de consumo de sal, alimentos com colesterol ou tabagismo, ocorreram somente no segundo grupo. A explicação para este fato é de que a utilização dos meios de comunicação de massa deve se somar também à educação face a face para que possa gerar mudança comportamental e ter maior probabilidade de ser mantida ao longo do tempo.

Existem alguns pontos negativos no tipo de tratamento dedicado ao tema saúde por parte dos meios de comunicação de massa. Normalmente a tônica recai em aspectos relacionados à doença e incapacidade sem referências a saúde e ao bem estar pessoal. Os temas normalmente abordados pela mídia, versam sobre medicina curativa de base hospitalar e curas espetaculares, associadas à venda de tecnologia médica, que produz lucros. Os meios de comunicação de massa têm como limitação o fato de não poderem veicular informações complexas, nem ensinar habilidades. Devem, portanto, ater-se a mensagens simples para não gerar ruídos na comunicação. Alem disso, já se disse, não geram, isoladamente, mudanças de comportamento. É importante que essas limitações sejam levadas em conta para que seja possível utilizar adequadamente esses meios, sem superestimar um poder que, na realidade, não têm. 
Com relação aos materiais de comunicação não dirigidos à grande massa, ou seja, materiais elaborados para grupos específicos, considera-se que eles são coadjuvantes em educação e promoção à saúde, desde que acompanhados por outras formas de intervenções. Desta forma, é importante avaliar as características de cada um dos recursos para que estes cumpram melhor a sua função. Tão importante quanto isto é a forma de utilização desses recursos, que poderá garantir um bom desempenho educativo. Na literatura são descritos critérios para avaliar destes tipos de materiais (EWLES E SIMNETT, 1992), como se apresenta a seguir:

- se o material é adequado aos objetivos - um exemplo é com relação aos materiais produzidos para lidar com a questão do tabagismo : se o público alvo for constituído por jovens não motivados para parar de fumar, um vídeo sobre como parar de fumar ou as vantagens de parar não irá atingí-los ; provavelmente seria mais adequado utilizar um vídeo que propiciasse e levantasse discussões, para que eles se conscientizassem de suas motivações.

- meio de comunicação mais adequado - o vídeo é útil pois pode ser editado ; a fotografia é mais barata, o cartaz também ; às vezes pessoas reais, ao vivo, contando suas experiências, são mais estimulantes do que filmes ou vídeos ; tudo precisa ser avaliado antes da escolha do tipo de recurso que se quer usar.

- é importante que o material seja consistente e coerente com os valores e com o tipo de abordagem que se quer dar ao problema: os autores colocam que não se deve culpabilizar a vítima, nem permitir mensagens que tenham conotações racistas .

- deve-se prestar atenção à relevância do tipo de abordagem ou do tipo de linguagem utilizada para um público específico, pois um erro pode inviabilizar a comunicação; é importante, portanto, prestar atenção às diferenças culturais.

- por se tratar de materiais destinados à promoção da saúde, deve-se evitar que estejam associados a empresas que produzam mercadorias "não saudáveis" ou que não estejam eticamente comprometidas. 
Entre os vários tipos de recursos que podem ser utilizados nas ações de promoção à saúde, o vídeo apresenta algumas vantagens. Por exemplo: a possibilidade de um maior realismo e a capacidade que tem de atingir mais de um sentido, facilitando a apreensão, a facilidade com que se pode passar informações, discutir problemas, demonstrar habilidades e propiciar discussões. Com vídeos pode-se atingir pequenas e médias audiências. Algo porém que precisamos questionar enquanto educadores, é a sua utilização isolada. Para que se tenha melhores resultados, torna-se necessário associar o uso de programas em vídeo cassete a atividades educativas mais amplas, não encarando a exibição de um vídeo como um fim em si mesmo.

Estudos que avaliam os efeitos do uso dos meios de comunicação em promoção à saúde, analisam também como estes meios atingem a audiência, tentando explicar as razões da aceitação ou rejeição das informações e valores veiculados (NAIDOO E WILLS, 1994,p.272-273). Uma das teorias é a "Hypodermic syringe" que considera a audiência como passiva e passível de manipulação. Outra teoria é a de "estágios", que aborda a importância do papel dos formadores de opinião, valorizando as interações pessoais. Apesar de representar um avanço com relação a primeira, ainda é um tanto simplista. O modelo dos "usos e gratificações" pressupõe que os meios sejam utilizados para gratificações pessoais. Dessa forma, a aceitação ou rejeição se daria por motivos pessoais. O modelo dos "efeitos culturais" vai um pouco além, pois supõe que os conteúdos veiculados são filtrados segundo padrões culturais e não só individuais.

As colocações acima referidas serão consideradas no presente estudo. A pesquisa será fundamentada nas premissas colocadas pelos autores citados no texto relativo aos aspectos teóricos do estudo.

Apresentam-se a seguir os objetivos deste trabalho. 


\section{OBJETIVOS}

\section{Geral}

Contribuir para a análise e avaliação dos recursos educativos audiovisuais utilizados em promoção e educação em saúde.

\section{Específicos}

1. A partir da listagem completa dos vídeos da videoteca agrupá-los em assuntos mais gerais do que os constantes no catálogo ( vide anexo 1)

2. Selecionar seis vídeos de três assuntos principais, sendo um de fiç̧ão e uma reportagem/documentário sobre cada assunto.

3. Analisá-los de acordo com as categorias de "corpo social", "político" e "existencial"

4. Estudar as características da veiculação dos conteúdos.

5. Analisar como a imagem do corpo é apresentada em termos de imagem, textos, sons, etc, ou seja, através dos recursos da linguagem audiovisual.

6. Interpretar os significados atribuídos ao corpo. 


\section{METODOLOGIA}

\section{$1^{\text {a }}$ Fase}

A partir dos materiais constantes do catálogo da videoteca (318 títulos), realizou-se uma seleção, segundo os critérios listados abaixo, de forma a separar os vídeos que tratassem mais especificamente do tema saúde:

- ser um programa produzido no Brasil;

- ser um material editado;

- não ter sido produzido por uma rede de televisão comercial;

- tratar mais especificamente do tema saúde;

- apesar de não ser específico sobre saúde, que possa ser utilizado em atividades de promoção, educação em saúde ou treinamento de recursos humanos na área da saúde;

- não ter sido produzido sob a forma de palestra ou aula, mesmo que tenha sido editado.

\section{$2^{\text {a }}$ Fase}

A partir da primeira seleção 162 títulos foram reagrupados em categorias gerais (anexo 1), mais amplas do que as constantes do catálogo. Foram selecionados 2 vídeos de cada um dos três primeiros assuntos mais freqüentes no acervo, sendo que em cada assunto foram escolhidos um do gênero ficção e outro de reportagem/documentário . 
Tabela 1: Distribuição de títulos de vídeo segundo assunto principal abordado

\begin{tabular}{lcc}
\hline ASSUNTOS PRINCIPAIS & $\mathrm{n}^{\circ}$ & $\%$ \\
\hline serviços de saúde / serviços públicos & 19 & 11,7 \\
saúde da mulher & 18 & 11,1 \\
aids / dst & 18 & 11,1 \\
qualidade de vida & 14 & 8,7 \\
adolescentes & 11 & 6,8 \\
saúde bucal & 11 & 6,8 \\
outros & 71 & 43,8 \\
\hline TOTAL & 162 & 100,0 \\
\hline
\end{tabular}

Fonte: Catálogo videoteca Cefor, São Paulo, 1997

A tabela acima permitiu verificar o número absoluto dos assuntos dos vídeos selecionados no Cefor. A partir dela selecionaram-se, para efeito da análise, os seguintes vídeos.

\section{Ficha técnica dos vídeos selecionados}

Vídeo1- Assunto principal : serviços de saúde / serviços públicos

Bianchi S, diretor. Divina Previdência. São Paulo: Sérgio Bianchi Produções Cinematográficas; 1984.9 min

VÍdeo 2- Assunto principal : serviços de saúde / serviços públicos .Atendimento Médico. Pernambuco: TV VIVA ${ }^{1}$ / SOS CORPO; $1985.10 \mathrm{~min}$

\footnotetext{
${ }^{1}$ TV VIVA : projeto ligado ao Centro Cultural Luiz Freire de Olinda (PE) , criado em 1984; produz programas que resgatam o humor, a arte e a descontração da população recifense, com gravações nas ruas, muita música e a preocupação em trabalhar com o cotidiano das pessoas, repleto de alegrias e problemas (SANTORO, 1989,p.79-79)
} 
Vídeo 3 - Assunto principal : saúde da mulher

Leocádio JL ,diretor. Amamentação: vamos recuperar esta prática? Rio de Janeiro: NUTES/UFRJ;1988.15 min

Vídeo 4- Assunto principal : saúde da mulher

Freitas A, diretor. Denise. Pernambuco : TV VIVA / SOS CORPO;1988.31 $\min$

Vídeo 5- Assunto principal : aids / dst

Marcello Domingues \& Xicão Alves. Mancha de Batom. São Paulo: Três Laranjas Comunicação/ Programa Estadual de DST/AIDS, Secretaria de Estado da Saúde de São Paulo; 1994/95. 27 min

Vídeo 6- Assunto principal : aids / dst

Quem vê a cara vê AIDS. Pernambuco: TV VIVA ; sem data; $15 \min$

$3^{\text {a }}$ Fase

A análise dos vídeos decorreu de uma etapa anterior que consistiu na descrição dos mesmos. De acordo com Aumont e Marie (1988), citados por PASSARELLI (1999, p.278) a descrição de um filme, ou de uma cena, já é um primeiro passo no processo de análise da obra cinematográfica.

A opção metodológica foi a de descrevê-los através de seqüências. Foram selecionadas algumas consideradas significativas para a análise dos três corpos : individual/existencial, social e político. Segundo PASSARELLI (1999):

Tal tipo de divisão (em seqüência) permite a identificação de blocos narrativos, isto é, "uma série de planos ligados por uma unidade narrativa, portanto comparável, em sua natureza, à cena no teatro ou 
ao quadro no cinema dos primeiros tempos." (....) A fim de determinar o início e término de uma seqüência, o analista deve procurar identificar os elementos da linguagem cinematográfica que podem funcionar como indicadores de mudança na unidade narrativa. Assim, um corte, uma alteração de um plano, a entrada de novos personagens, alterações na trilha sonora ou no tempo cronológico da narrativa, enfim, esses e outros elementos podem servir como pontos, vírgulas, isto é, fronteiras e suspensões entre uma seqüência e outra. (PASSARELLI 1999, p.90/279-280).

Foram selecionadas algumas seqüências consideradas representativas para configurar as três faces do corpo e as oposições que nelas se apresentam. Essa seleção deu-se em função do impacto causado por determinadas cenas. Esse impacto pode ser entendido no sentido que BARTHES (1984) refere com relação às imagens fotográficas, segundo os conceitos de studium e punctum. Apesar das imagens videográficas estarem num suporte diferente da fotografia, elas possuem características comuns a outras imagens. Para o autor o studium seria o que a foto denota, aquilo também que revela as intenções do fotógrafo informadas pela cultura em que vive. (BARTHES, 1984, p.45-48). Segundo esse autor:

O segundo elemento vem quebrar (ou escandalizar) o studium. Dessa vez não sou eu que vou buscá-lo (....) é ele que parte da cena, como uma flecha, e vem me transpassar. Em latim existe uma palavra para designar essa ferida, essa marca feita por um objeto pontudo; essa palavra me serviria em especial na medida em que remete também à idéia de pontuação e em que as fotos de que falo, são, de fato, como que pontuadas, as vezes até mesmo mosqueadas, com esses pontos sensíveis; essas marcas, essas feridas são precisamente pontos. A esse segundo elemento que vem contrariar o studium chamarei então punctum; pois punctum é também picada, pequeno buraco, pequena mancha, pequeno corte - e também lance de dados. $O$ punctum de 
uma foto é esse acaso que, nela, me punge ( mas também me mortifica, me fere) (BARTHES, 1984, p 46) .

Para o autor "(....) o detalhe que me interessa não é, ou pelo menos não é rigorosamente intencional, e provavelmente não é preciso que o seja" (BARTHES,1984,p76) ; é a emoção que a imagem produz, que normalmente não é nomeável. "O studium está, em definitivo, sempre codificado, o punctum não (....) é o que acrescento à foto e que todavia já está nela" (BARTHES,1984, p.80/85). O autor coloca que no cinema não há tempo para o espectador acrescentar algo à imagem em decorrência da submissão ao que denomina de "voracidade contínua" das imagens na tela. Porém MORIN (1983) coloca a possibilidade deste espaço de reconstrução em função do processo de projeção/ identificação (abordado na p. 25 deste trabalho) que explica qual o processo que permite que as emoções sejam despertadas e elaboradas a partir do momento em que se assiste e se reflete sobre um filme.

$\mathrm{Na}$ análise trabalhou-se a partir do ponto de vista do studium na medida em que buscou-se compreender as determinações culturais que possam ter condicionado o uso dos recursos de linguagem . Na seleção das seqüências, porém, levou-se em conta o punctum .

\section{$4^{\text {a }}$ Fase}

As representações do corpo nos vídeos foram interpretadas em termos das dimensões individual/existencial, social e política. Observou-se como o indivíduo, personagem, em caso de ficção, e entrevistados, no caso de documentários, são apresentados e como eles percebem o próprio corpo, como enxergam a si próprios. A forma com que os indivíduos se vêem é condicionada também por aquilo que a sociedade em que vivem configura. Do ponto de vista social, como os outros, representando determinadas estratificações da sociedade, vêem o indivíduo e o que condiciona esta visão. Por último, que relações de poder são configuradas nessas interações. 
A partir dessas dimensões construíram-se algumas categorias empíricas que facilitassem a análise das imagens, permitindo relacionar a linguagem audiovisual com o conteúdo representado. Estas perguntas permitiram observar os materiais de forma mais sistemática captando o conteúdo e a forma com que estas questões são configuradas, ou seja quais e como os recursos de linguagem são utilizados para representar as três dimensões do corpo.

Foram analisados movimentos, gestos, expressões e falas visando estudar o corpo enquanto sede de representações sociais e culturais. Sabemos, de acordo com MAUSS (1974), que a sociedade conforma as diversas atitudes corporais dos indivíduos.Conforme destaca o autor : "Esses hábitos variam não simplesmente com os indivíduos e suas imitações, mas, sobretudo, com as sociedades, as educações, as conveniências e as modas, com os prestígios. É preciso ver técnicas e a obra da razão prática coletiva e individual, ali onde de ordinário vêem-se apenas a alma e suas faculdades de repetição." (p.214) De acordo com isso procurou-se interpretar as expressões corporais buscando suas origens culturais, sociais e históricas.

As expressões corporais nos vídeos são mostradas de forma a retratar aquilo que o(s) autor (es) se propõem. A autoria de um produto audiovisual é coletiva, participando dela tanto o diretor, quanto o roteirista e as instituições produtoras. Este coletivo é integrante de uma determinada cultura num certo momento histórico, sendo que suas opções ideológicas e estéticas são por ela condicionadas. Desta forma, num outro sentido, é importante e necessário analisar também como são utilizados os diversos recursos de linguagem visando fornecer os significados da mensagem. Estes recursos, por sua vez, conformam as expressões do corpo, contribuindo na configuração dos sentidos das atitudes corporais. Devemos nos lembrar que as imagens não são uma mera reprodução do real, ou seja , o produto audiovisual é uma construção a partir deste. O roteiro, os recursos de edição, movimentos de câmera, enquadramentos, áudio, cores e cenários fornecem informações sobre as concepções de corpo subjacentes, 
relacionando-se neste sentido à função simbólica da imagem (AUMONT, 1993). Para captar isto é necessário um outro tipo de olhar sobre o material, um olhar que busque discriminar e desmontar um discurso que é ao mesmo tempo verbal, sonoro e imagético e que se desloca num espaço e em um tempo.

As perguntas colocadas a seguir visaram, então, clarear o tipo de abordagem do corpo da mulher, do homem, do paciente/usuário, do profissional, etc., construído e apresentado naquele material. Buscou-se estudar o conteúdo simbólico configurado nas imagens construídas.

Para observar a configuração do corpo individual/existencial:

- Qual a percepção pelo sujeito do seu próprio corpo no mundo? Como o indivíduo vê seu corpo: Qual é meu corpo? O que me diferencia dos outros? Como é meu corpo para mim? Quais sensações ele me desperta ? Como percebo que meu corpo é para os outros (família, profissionais de saúde, sociedade em geral)?

- Para observar a configuração do corpo social:

- Como o corpo do indivíduo é visto pelos outros (amigos, família, profissionais de saúde, instituições)?

- Como o indivíduo vê os outros?

- Configuração do corpo político:

- Quem tem poder, exerce um domínio, sobre o corpo do indivíduo?

- Como as oposições são configuradas:

- O que, no corpo, é condicionado pela natureza? O que, no corpo, é condicionado pela cultura?

- O corpo é visto na sua totalidade integrada? O corpo é visto como uma soma de partes ? Quais partes são mais valorizadas? Quais aparecem pouco?

- Quais cuidados dispensados ao corpo são colocados como de responsabilidade do indivíduo ? Quais são de responsabilidade dos "outros"? 
Foram construídas perguntas dizendo respeito especificamente aos elementos de linguagem, sobre a forma de utilização dos mesmos ao retratar os corpos dos personagens e entrevistados. Retomando o que foi apresentado no capítulo dos aspectos teóricos relativos à comunicação, buscou-se analisar os recursos de expressão.

- O que é visto de perto e o que é visto de longe?

- Os corpos dos indivíduos são mostrados em planos gerais ou em detalhes?

- Quais partes do corpo são mostradas em detalhes? Quais não aparecem com freqüência?

- Como se dá o enquadramento da imagem?

- Qual o ângulo de visão?

- Em que cenário estão os indivíduos? Como o espaço de cena é trabalhado? Que tipos de objetos compõem este cenário? Quais os significados destes objetos na configuração do corpo?

- Quais os recursos sonoros utilizados (ruídos, músicas, voz em "off", etc.)? Qual o seu papel no tratamento do tema?

- De que forma se utiliza a edição? Que tipos de recursos (corte, fusão,etc) são utilizados ? Que tipo de relação é estabelecido entre as imagens na edição? Como elas são combinadas neste processo?

- De que forma o fator temporal é trabalhado? São mostrados o passado (lembranças) e o futuro (sonhos, devaneios)? Há intercâmbio entre estas dimensões temporais?

- São utilizados outros recursos, como computação gráfica? Com que finalidade?

- Quais as diferenças na abordagem segundo o gênero de comunicação em que o vídeo foi estruturado?

- Quais são os movimentos e gestos escolhidos para representar o corpo nos vídeos ficcionais ? Quais as sua funções? 
Nem todas as perguntas foram necessariamente respondidas em todos os vídeos. Em cada material alguns elementos de linguagem são mais trabalhados e reforçados, tornando-se mais importantes e dirigindo de certa forma o olhar e a análise.

Existe ainda um terceiro plano de análise em que o corpo pode ser pensado. Diz respeito à forma com que o material propõe a aproximação com o espectador. Algumas vezes os personagens ou os repórteres dirigemse diretamente a ele. Outras vezes através de recursos de linguagem percebemos que existe uma preocupação em atingir mais diretamente o emocional daquele. Através de closes, músicas, ou outro recurso, busca-se um contato mais direto com o corpo do espectador, fazendo com que seja possível comunicar sensações e mexer com sua percepção. Neste estudo não há comprovação de que isto tenha sido possível, pois para isso seria necessário um estudo de recepção, mas podemos observar se o material contém este tipo de preocupação e quais recursos são utilizados com esta finalidade. 


\section{RESULTADOS E DISCUSSÃO DE DADOS: SINOPSE , DESCRIÇÃO DE SEQÜÊNCIAS E INTERPRETAÇÃO DE CADA VÍDEO SELECIONADO}

\section{Vídeo 1: Divina Previdência.}

Sinopse: Ficção que aborda as atribulações de um mendigo ferido às voltas com funcionários públicos, documentos e prontuários da Previdência Social. A burocracia, a violência da cidade e a falta de recursos fazem dele mais uma vítima do desespero.

\section{Seqüência 1: (S1)}

Protagonista, mexendo numa ferida que tem no rosto, esperando sentado numa fila para tirar documentos ; o som é de um programa de rádio com narração de Gil Gomes; “... se eu fosse você eu saía daqui...” ; closes de homens na fila; plano geral e médio da fila; o desespero vai tomando conta dele; ele se levanta, olha em volta, dá um grito e sai correndo / corte/ ouvemse os gritos do personagem batendo numa porta branca de ferro com cadeado / corte

\section{Seqüência 2: (S2)}

Numa sala de arquivo, ouve-se uma voz e uma funcionária saindo de trás das prateleiras lotadas com pastas : “... se houver necessidade para a história para o futuro, está tudo aqui; nós temos a história de cada um, suas razões, suas contradições, seus porquês; não podemos fazer mais nada, estamos em crise..." ; a funcionária guarda um processo/ corte 
Seqüência 3 : (S3)

O protagonista em close mexe na ferida frente ao espelho e ouve-se um grito de mulher/ corte/ close das mãos do personagem cortando o pulso; close do rosto/corte

Este vídeo, originalmente um curta-metragem, é obra de um cineasta não tendo sido produzido com uma finalidade instrutiva. Tem o objetivo de denunciar, incomodar e gerar reações. Não existe uma preocupação em delinear várias abordagens, vários pontos de vista, ele visa gerar uma reação emocional de um certo incômodo, espanto e raiva. Em conversas informais, durante o período que trabalhei no centro de documentação, profissionais de saúde usuários da videoteca comentaram que, ao assisti-lo, tiveram uma sensação desagradável, principalmente pelo tipo de abordagem agressiva. Não se pode dizer que ele não "administra" o ciclo emocional (conceito utilizado por AUMONT, 1995), porém provavelmente não o faz de uma forma completa, da forma que os espectadores esperariam. Possivelmente a opção do autor seja esta mesma, a de não oferecer alternativas, deixando algo incompleto para gerar uma reação. A forma com que a narrativa é conduzida leva o espectador a não ver opção para a situação, não são mostrados outros pontos de vista sobre a situação para amenizá-la. O final trágico, em que o protagonista se vê sem saída, é de certa forma esperado, porém gera um desconforto.

Na seqüência em que vemos uma mulher que atende o protagonista e em outros detalhes inseridos no decorrer do vídeo (Figuras 1 e 2 ) a câmera fica próxima, criando uma deformação, o rosto fica grande, e o corpo da representante da instituição adquire um peso. $O$ que se sente como exagero cria um efeito que expressa um ponto de vista do autor, uma idéia, enfim, é um recurso expressivo (AUMONT, 1995,p.290). A proximidade da câmera em certas imagens, os chamados closes, ou mesmo os primeiros planos, (por ex na S3) relacionam-se com a questão da distância psíquica, teoria sobre a qual Aumont cita vários autores que a defendem como Panofski e Deleuze (AUMONT,1995, p.109-110). A proximidade da imagem "em que 
se insiste mais na presença dos objetos, suas qualidades de superfície, etc." (Hildebrand citado por AUMONT) traz uma sensação tátil (visão de pertopólo háptico) em oposição ao pólo óptico (visão de longe) em que a perspectiva desempenha um papel maior. Estes closes, e também as imagens em primeiro plano não se colocam como elementos de linguagem isolados, no geral o vídeo vai criando um clima de envolvimento, de tensão, e por causa deste contexto talvez a proximidade gere esta sensação de uma presença mais forte, mais tocante, no sentido de tato, de sensação tátil (S1 e S3).

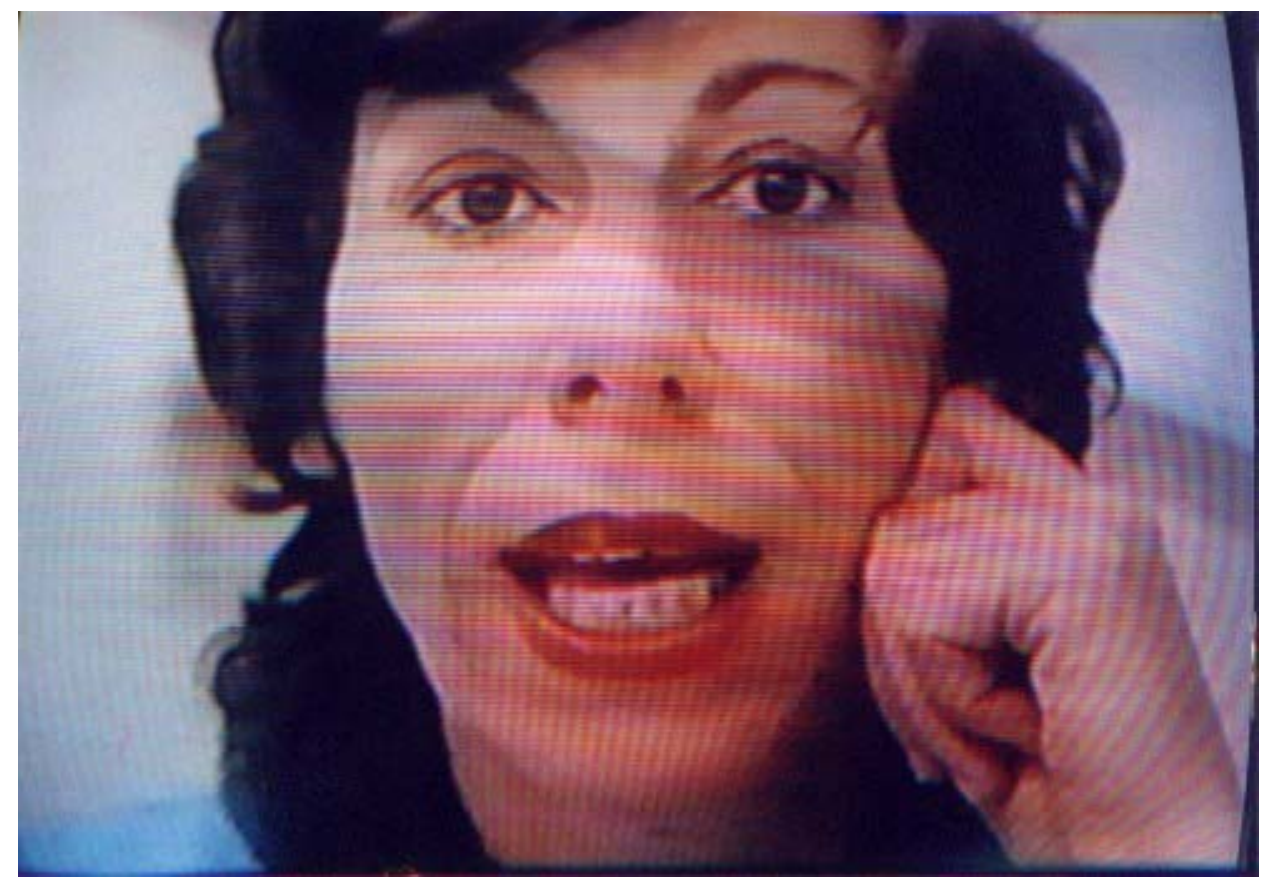

Figura 1 


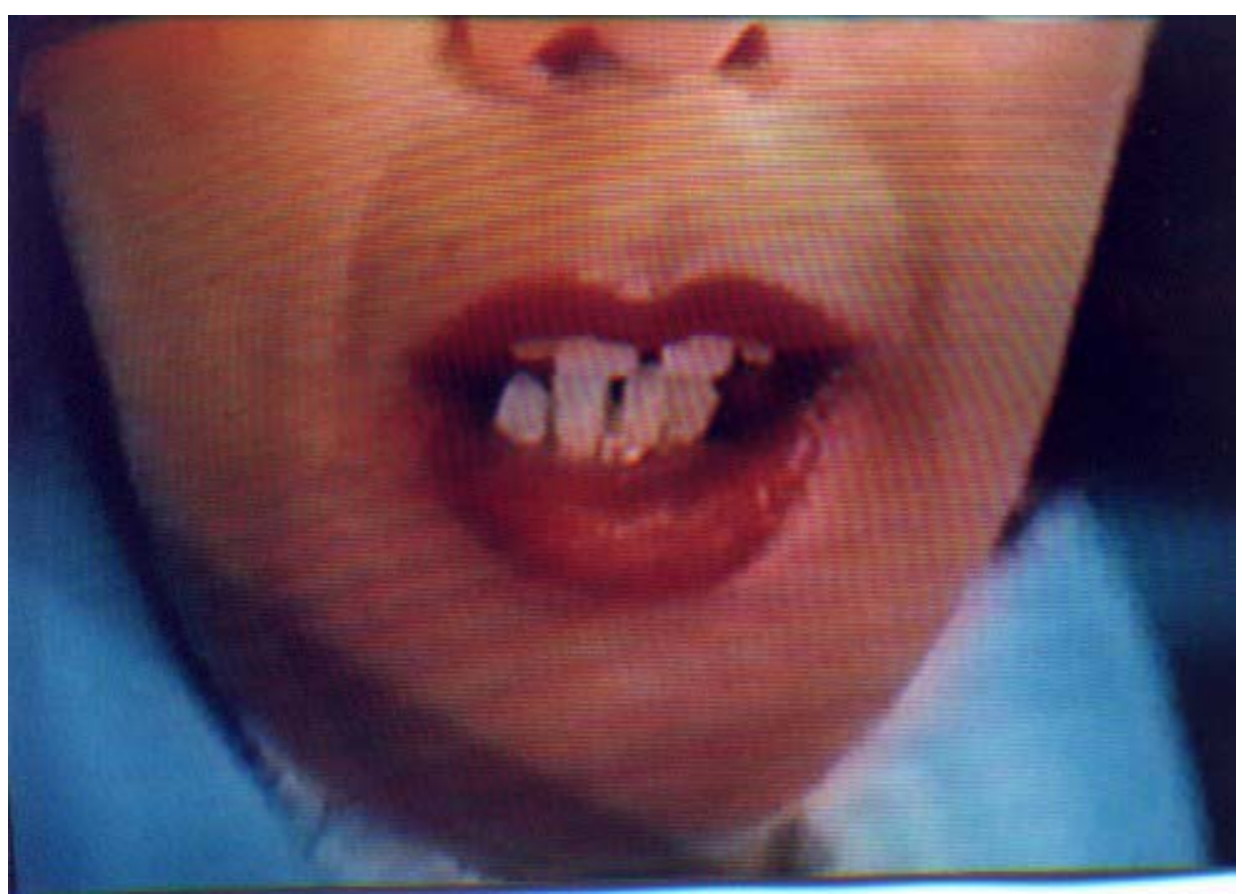

Figura 2

A proximidade e o clima que o vídeo vai criando faz com que o espectador se aproxime da sensação de dor; as imagens da ferida, do sangue tocam nos sentidos, gerando uma certa repulsa. Podemos ver nesta forma de expressão que o corpo do espectador é de certa forma "tocado" . A configuração do corpo na tela influencia o corpo de quem assiste ao material, remetendo-se à percepção dos sentidos, dizendo respeito também ao corpo existencial do espectador.

Apesar de não ter as características tradicionais, atribuídas aos filmes expressionistas, como a estilização, deformação e abstração (BETTON,1987, p.54) talvez existam algumas semelhanças por não existir uma preocupação com a representação objetiva do real. Apesar de utilizarem-se cenas realistas, como, por exemplo, a longa fila, não existe a preocupação prioritária com que a imagem tenha uma função representativa (AUMONT, 1995, p.294). O exagero na configuração da ferida passa uma idéia de excesso, configurando um tipo de imagem exacerbada. A proximidade de certas imagens, citada acima, também colabora para criar esta amplificação. O vídeo apresenta uma visão muito particular da realidade e uma visão muito pessoal do diretor. Os filmes expressionistas têm esta 
característica muito pessoal de autor, com uma grande valorização da subjetividade, ou seja, ela se apresenta claramente (AUMONT, 1995, p.295).

Dos seis vídeos analisados este é o que mais coloca o corpo existencial/individual. Apesar de não sabermos a história do personagem, a forma com que ele é representado, segundo os recursos de linguagem citados acima, faz com que possamos sentir o seu drama de perto e perceber como a sua história de vida lhe confere um modo peculiar de enxergar o mundo e de reagir a ele. Em algumas seqüências, como quando ele é atendido nos guichês das instituições ou na cena final no cinema, a câmera funciona como o olho do protagonista, dirigindo o olhar do espectador pelo seu ponto de vista. Vemos então as cenas através de seu olhar, conferindo uma dimensão existencial às seqüências. Em outras cenas a câmera opera com o ponto de vista do observador, do espectador, de alguém de fora que é encaminhado para o contexto do vídeo.

Os indivíduos nas filas, espalhados na multidão, são silenciosos, parecem que não têm história, porém suas imagens sensibilizam. 0 enquadramento das imagens, em close, faz com que eles fiquem próximos de nós, espectadores (Figura 3) .

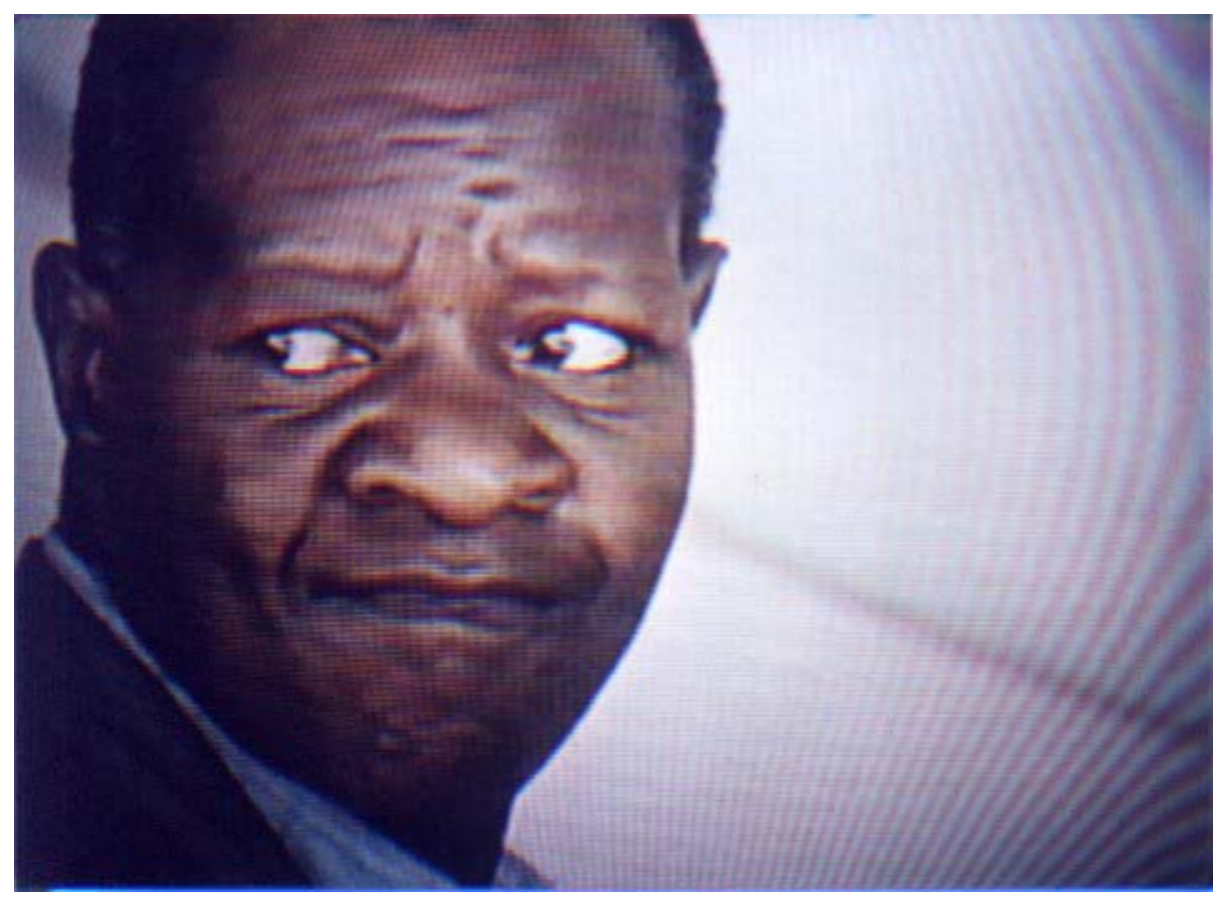

Figura 3 
A ferida do mendigo fala por ele; seu corpo se manifesta. A ferida tem cor, uma aparência feia, seu corpo denuncia uma ferida maior, decorrente da miséria e do abandono. A ferida adquire maior valor expressivo por estar localizada no rosto, parte do corpo com maior visibilidade. A expressão da doença no seu rosto confere uma maior expressividade, pois em nossa cultura o rosto é muito valorizado. SONTAG (1989), ao analisar as metáforas da aids, coloca a importância desta parte do corpo para nossa cultura :

Pois, por mais que a filosofia e a ciência moderna tenham atacado a separação cartesiana entre mente e corpo, não foi nem um pouco afetada a convicção de nossa cultura referente à separação entre rosto e corpo, que influencia todos os aspectos dos costumes, modas, apreciação sexual, sensibilidade estética - praticamente todos os nossos conceitos do que é correto. (....) O próprio conceito de pessoa, de dignidade, depende da separação entre rosto e corpo, da possibilidade de que o rosto esteja isento - ou ele próprio se isente - do que está acontecendo com o corpo (SONTAG,1989, p. 47-48).

A apresentação da ferida no rosto do personagem impossibilita que se faça esta separação entre o rosto e o resto do corpo; ela passa a representar o sofrimento do corpo como um todo (Figura 4 ). 


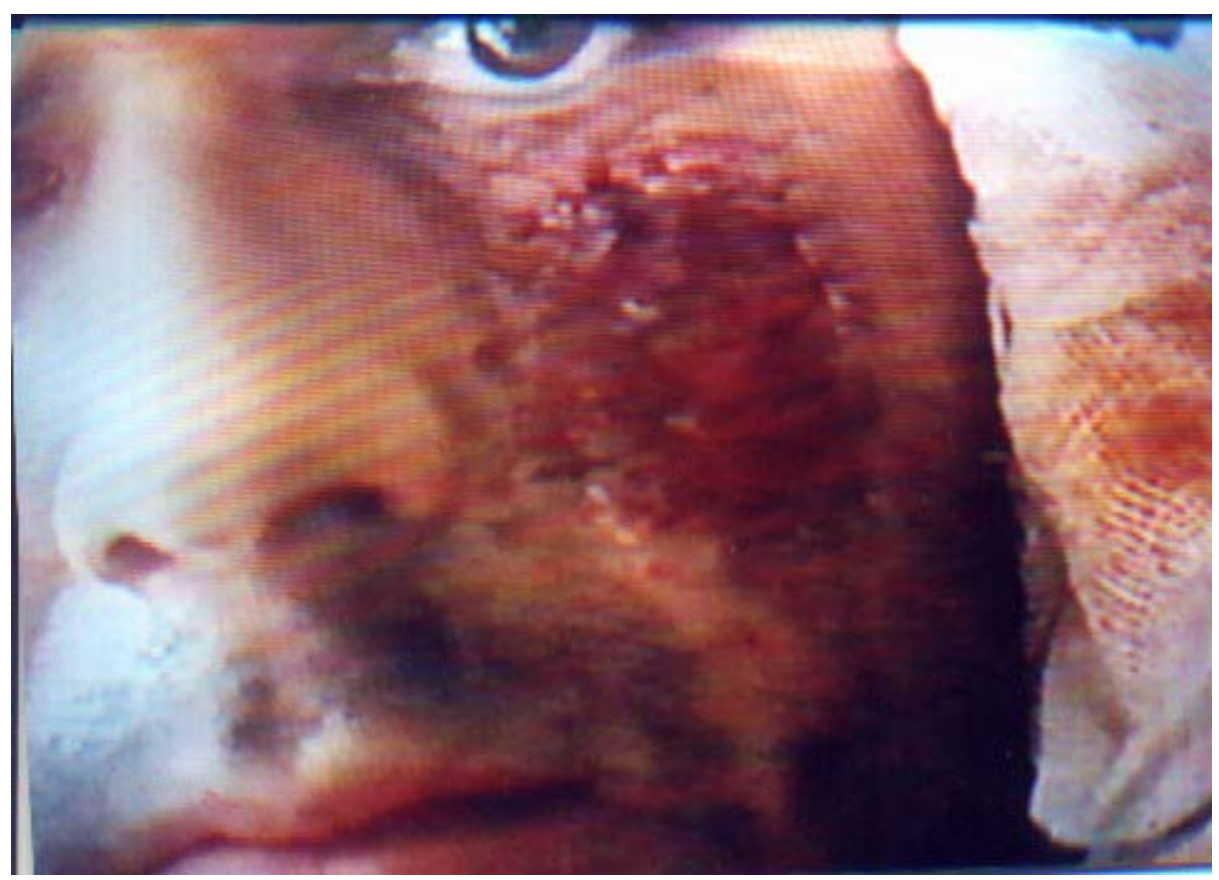

Figura 4

Outra parte do corpo enquadrada em detalhe é a mão do personagem, signo que representa a ação, força. A ação que ele realiza, porém, não é a do enfrentamento do mundo, mas uma ação voltada contra ele mesmo, executada no momento em que, ao cortar o pulso, ele tira a própria vida (Figura 5).

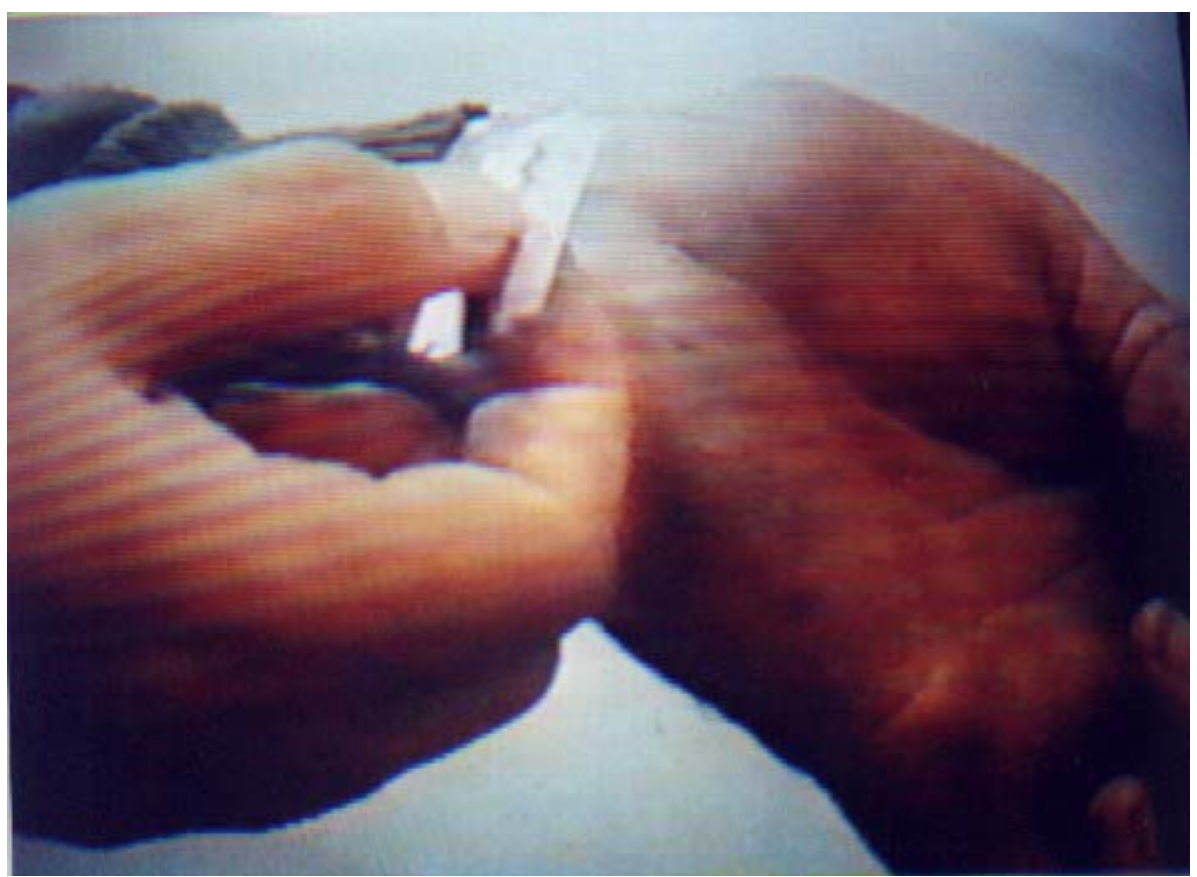

Figura 5 
Outra imagem que é significativa e enquadrada em primeiro plano é , na S1, a porta branca de ferro com cadeado, que representa fisicamente a barreira existente entre as pessoas comuns e a instituição e seus representantes.

O diretor dá a voz aos representantes da instituição, com um discurso impositivo, e depois a uma certa camada da sociedade, representada pelo casal na tela do cinema ( Figura 6), que profere um discurso agressivo.

A opção por não dar voz ao protagonista parece proposital e provocativa, utilizada para reforçar sua impotência frente à situação. Seu silêncio é um objeto acústico tão importante como as falas e os ruídos. Ele, porém, está cheio de palavras, é um silêncio que quer dizer muita coisa, tem um significado (JAKOBSON, 1970,p.157) . A fala não é simplesmente algo exterior aos objetos e ao mundo, somente uma forma de denominá-los. De acordo com MERLEAU-PONTY (1971) é necessário que a palavra e a fala deixem de ser uma vestimenta para os objetos ou para o pensamento, para tornar-se uma presença, seu emblema, seu corpo (p.192). O protagonista não possui nada, nem mesmo a fala, é como se ele não tivesse a posse nem mesmo de seu corpo, é a negação deste como expressão existencial, política e social. As palavras que habitam o seu silêncio têm raiva e espanto, que são ditas pelos outros no vídeo. Os discursos proferidos, seja pelos representantes da instituição, seja pelo casal no cinema, remetem ao corpo político: o poder está do lado deles. 


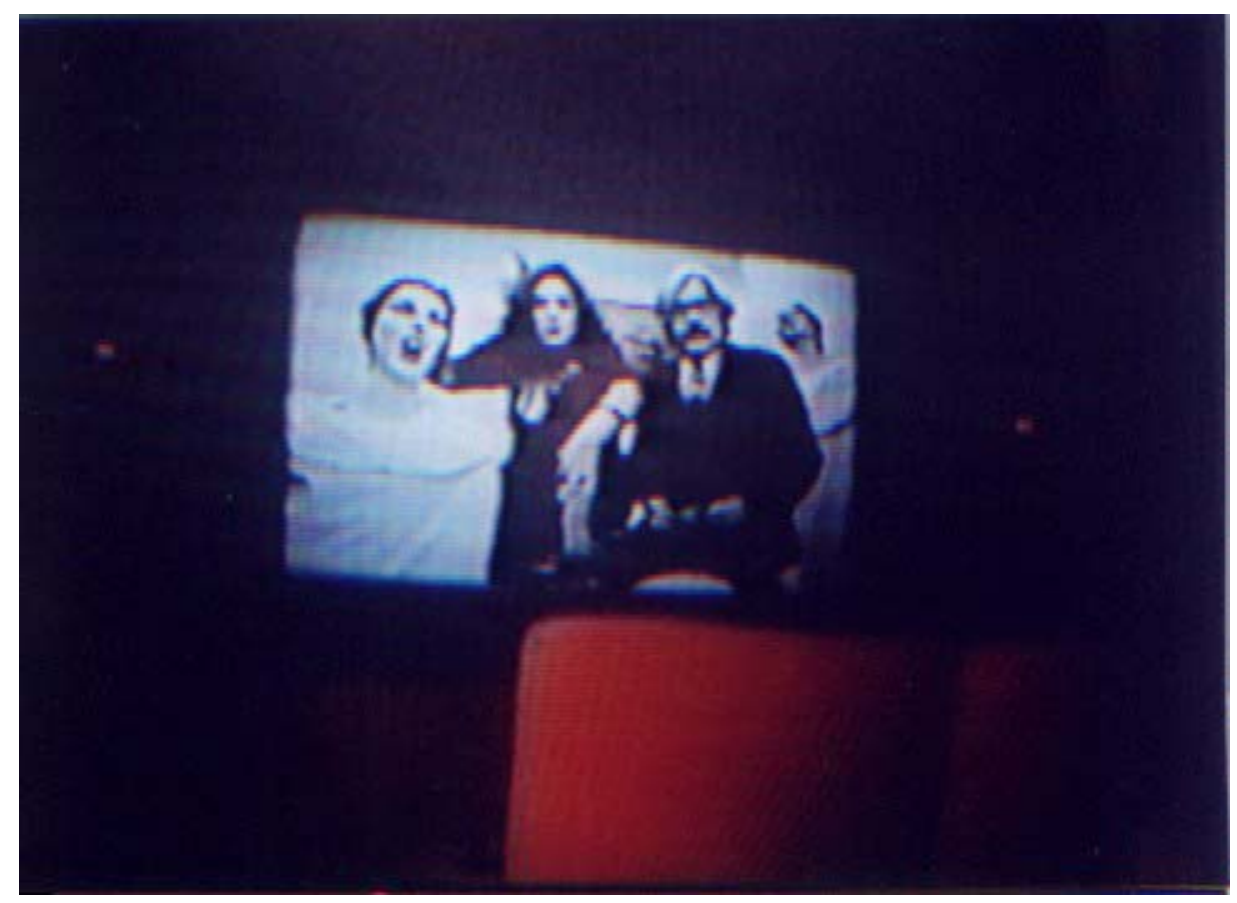

Figura 6

Na seqüência final, no cinema, vemos um filme, em cujo cenário estão um casal e algumas esculturas. No plano mais próximo a escultura , de boca aberta, tem uma expressão como se estivesse gritando (Figura 7), semelhante ao quadro expressionista “O grito" de Edvard Munch (1893). De acordo com CHEVALIER (1997) o grito tem algo de maléfico e paralisante, além de poder ser um protesto. Por ser uma estátua - não tem movimento- a idéia de paralisia é acentuada. Provavelmente seria o grito que o protagonista daria, como protesto, mas que não pode ser expressado; ele está paralisado e seu olhar é de espanto. O teor maléfico fica por conta do discurso do casal, que se dirige a ele com palavras agressivas, deixando o espectador também um pouco espantado. Escutamos também um grito na cena anterior a esta, em que o protagonista se olha no espelho antes de cortar o pulso. 


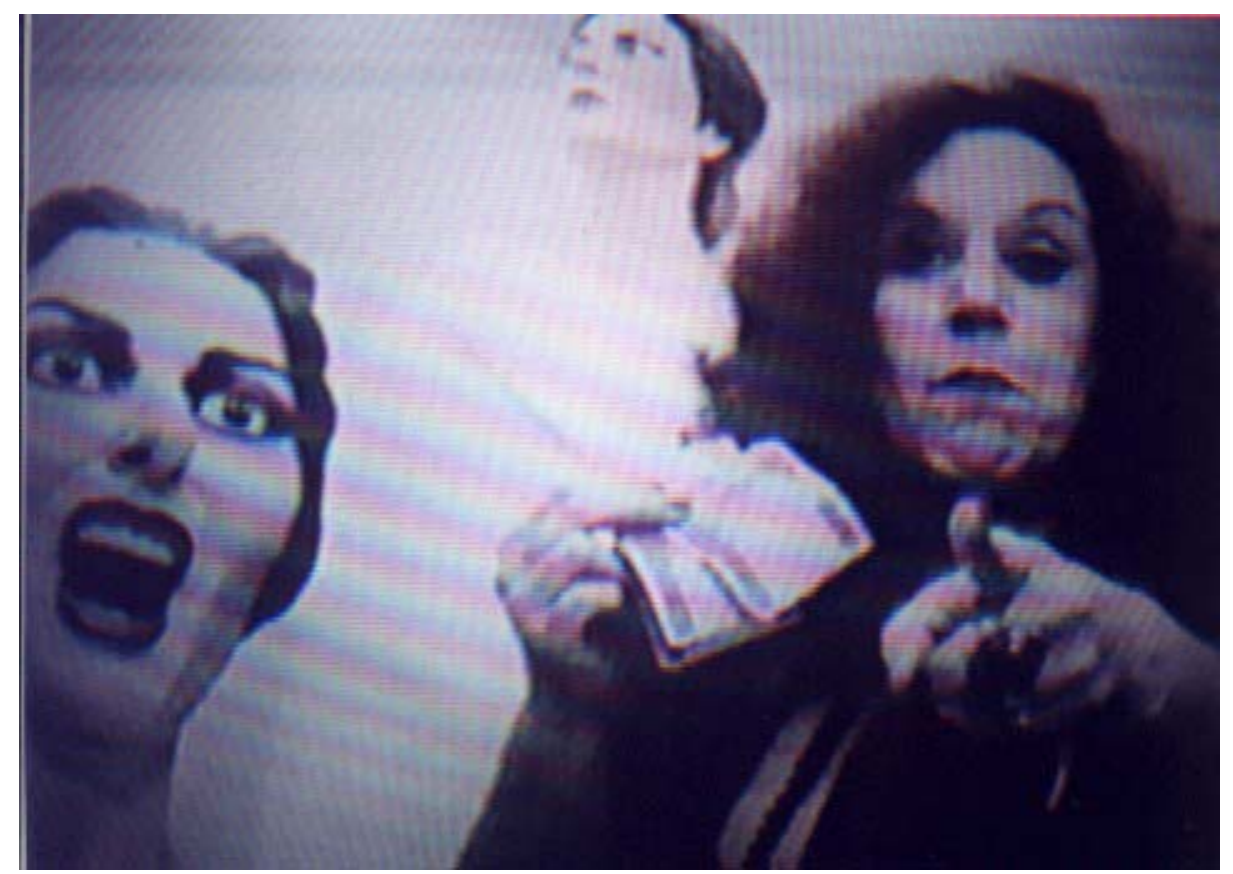

Figura 7

O fundo musical colabora para intensificar a mensagem, ao reforçar as situações ou ao se contrapor a elas. Em algumas seqüências, próximas do início e do final , o diretor optou por músicas americanas leves e ligeiras (cantadas ou não), adquirindo mesmo um tom ingênuo ao se contrapor à dureza das imagens exibidas, gerando uma estranheza por serem radicalmente opostas às imagens de desespero apresentadas. Durante os momentos tensos a música colabora para compor as cenas, criando o clima que vai levar ao desfecho, ao clímax. Novamente ao final ele quebra o clima nos forçando a ver o paradoxo.

É utilizado neste vídeo o recurso ao fantástico, à magia. Na cena final quando o protagonista entra na sala de um cinema, os atores de um filme começam a falar se dirigindo a ele, deixando de conversar apenas entre si. Esta forma de tratamento, além de fornecer um toque de fantasia, coloca-se como uma reflexão sobre a própria linguagem (função metalingüística). 0 cinema, o vídeo, a televisão se dirigem a nós e falam sobre nós e a nossa vida, como que se saíssem da tela, do aparelho de tv, e entrassem em nossa intimidade. O casal não chega a sair fisicamente da tela, mas se 
coloca, de uma certa forma, do lado de fora dela, invadindo a vida do protagonista.

Numa das seqüências finais o personagem, atormentado, se olha no espelho. Nesta cena há um momento em que a câmera focaliza seu rosto no espelho, o rosto refletido, a imagem invertida. Ele se olha e se desespera cada vez mais. De acordo com CHEVALIER (1997) entre o sujeito contemplado e o espelho que o contempla se estabelece uma relação ( $p$. 396). Nesta relação se dá uma transformação, na medida em que o sujeito acaba por ver a beleza ou, como no caso deste vídeo, aquilo que ele não queria; ou seja, o espelho pode refletir também um lado tenebroso. Podemos pensar também que o que ele vê através do espelho, revelado de certa forma por este, daí a força deste símbolo no vídeo, é algo que a sociedade prefere não ver, prefere afastar para bem longe.

Estas observações apresentadas acima são ditas, de certa forma, pelo casal na tela do cinema, na seqüência final. Nesta cena homem fala para o protagonista, de dentro da tela do cinema, que é melhor ser rico saudável do que pobre doente e que ele deve mesmo morrer, configurando uma dicotomia que se busca resolver pela destruição de um dos pólos .

O casal aparece numa posição superior, no alto do quadro da tela, fortalecendo o eixo vertical, e proferem frases que configuram a visão do protagonista, e de tudo que ele representa, como algo que deva ser excluído. O protagonista, por sua vez, encontra-se numa posição- sentado na cadeira do cinema, com o corpo largado - em que o eixo horizontal é reforçado. Percebemos nesta oposição (vertical/horizontal) que a questão do poder é novamente apontada. O eixo vertical nos dá uma idéia de superioridade, de poder, de ação, de domínio. Por sua vez o eixo horizontal nos informa sobre a passividade e a submissão .

RODRIGUES (1999) argumenta que a sociedade contemporânea busca se garantir contra a doença, a morte, a miséria. Ao se referir à questão do lixo em nossa sociedade ele aponta que: "Em termos mais sintéticos, o cumprimento da promessa requer aniquilamento do que esta sociedade considera dejetos, pois estes carregam simbolicamente ameaças 
de degenerescência e morte." (p. 91) O personagem, que é um mendigo, é considerado como lixo, como algo a ser excluído. Ele representa aquilo que os outros não querem ser, mas que paradoxalmente o sistema cria incessantemente.

A representação da doença no corpo do indivíduo serve como referência para abordar a doença no sentido mais amplo, ou seja "a doença social". A analogia entre sociedade e corpo faz com que o corpo humano seja tratado como uma imagem da sociedade. Se a sociedade é encarada como algo que deva ser purificada, o impuro deve ser banido. Na medida em que se supõe a pureza, a impureza se impõe como contrapartida, configurando uma dicotomia. Se o objetivo é a busca da pureza do corpo , o impuro deve também ser banido, sendo que isso pode ser realizado das mais variadas formas. Segundo O'NEILL (1985) e DOUGLAS(1970), em todas as sociedades existem comportamentos relacionados à questão da sujeira corporal. Partes do corpo, funções corporais, corpos inteiros ou classes de corpos são considerados fontes de pureza ou poluição . A atitude que se toma normalmente é de evitar a própria sujeira, tirá-la de perto, assim como evitar a dos outros. Neste material estudado pode-se pensar que o mendigo representa aquilo que a sociedade busca eliminar : a doença, a feiúra. o mau-cheiro, a poluição, a impureza. Sua ferida, a sujeira de suas roupas, são a representação no corpo destas impurezas. 


\section{Vídeo 2: Atendimento Médico}

Sinopse: Reportagem/documentário que denuncia o autoritarismo e falta de atenção dos médicos no atendimento às mulheres, através de depoimentos de usuários, nas filas, no grupo de discussão e de profissionais de saúde.

\section{Seqüência 1: (S1)}

Inicia com um close de uma senhora idosa debruçada na janela de uma casa observando; câmera abre para a imagem de outra senhora com uma criança no colo. Vai subindo uma voz com um depoimento enquanto há um corte na imagem para plano geral de uma mulher e duas crianças/ corte/ detalhe das mãos de uma mulher integrante de um grupo reunido num local a céu aberto que discute o atendimento médico.Ouve-se a voz de uma mulher perguntando às outras:

- Vocês acham assim que as mulheres de uma maneira geral elas conhecem bem o corpo dela e são sabidas em relação ao que tá acontecendo aqui dentro ?

Do detalhe das mãos abre-se para o corpo inteiro de uma mulher sentada no chão com as pernas cruzadas quando se inicia um outro depoimento. Depois se corta para a imagem da mulher que está falando:

- Dizer assim que a gente se conhece bem, a gente sabe, quando a gente tá com aquela dor, onde é aquela dor, como é...; não ter medo de ir no médico e dizer : "Doutor, eu tô sentindo é aqui..." , não, a gente não sabe, eu mesmo não sei não, não sei as outras, mas meu corpo, eu acho que por dentro eu me conheço pouquíssimo.

Movimento da câmera vai descendo pelo corpo da mulher e enquadra detalhe das mãos cruzadas no colo de uma outra (Figura 8), passando para as mãos da que está ao lado. Ao mesmo tempo sobe o som de um terceiro depoimento enquanto em primeiro plano vemos o rosto de uma mulher observando e ouvindo a colega/ corte para o rosto desta que fala:

- Eu pergunto: se eu estou sentindo, eu tenho que lutar, porque se eu não disser a ele o que eu estou sentindo ele jamais vai se interessar 
pelo meu problema; quem tem que brigar mesmo sou eu... Se eu não brigar é ele que vai brigar? Ele não vai fazer nada!

Corte.

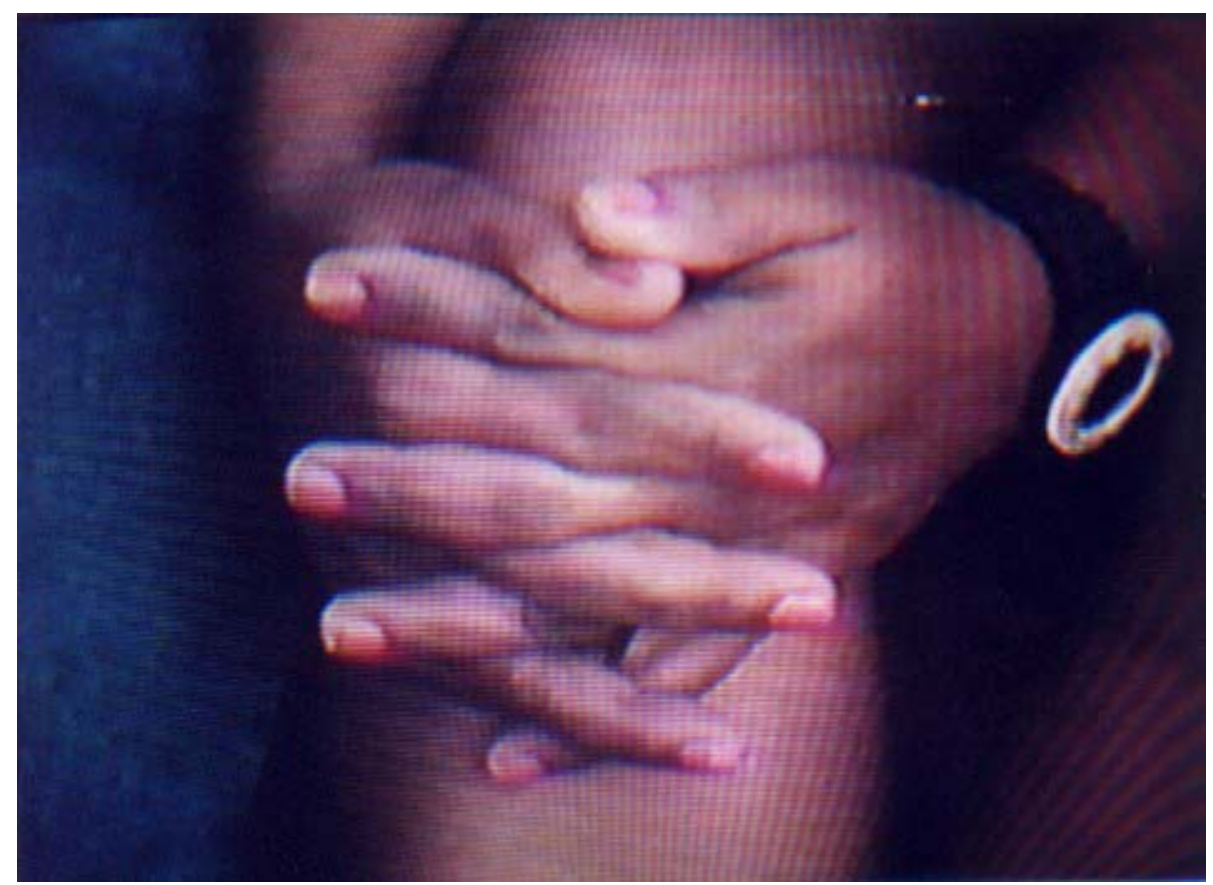

Figura 8

Seqüência 2: (S2)

Abre com uma música instrumental e a imagem de uma cena na televisão na sala de uma casa. Câmera abre e caminha para fora da casa, enquadrando um conjunto de moradias simples/ corte/ câmera dá uma panorâmica sobre este local e sobe o áudio com a fala de uma mediadora (entrevistadora) de um grupo de discussão:

- Como que ia ser este atendimento médico que a gente imagina como melhor, que a gente vai gostar mais, né, como é que seria este atendimento médico para vocês, o ideal?

Plano geral do grupo/ corte para close de uma das mulheres enquanto sobe o som do depoimento de uma outra.

Seguem-se closes de outras integrantes do grupo. 
- Todo médico devia ser como a Janete, a que faz prevenção no José Bonifácio, devia ser como ela, mostrar a gente, pegar um espelho... (risos)

- O que ela faz, como é que ela faz?

Seguem-se closes das mulheres enquanto uma delas fala, depois ela é focalizada no grupo.

- Ah, ela é muito legal, ela mostra a gente, dá o bico de pato que a gente tem que colocar, e pega um espelho, e ajuda a gente se levantar, e mostra. Todo médico devia ser como ela, se fosse ninguém tinha medo de ninguém, né?

Corte para outro depoimento:

- Ela explica tudinho prá que serve, faz palestra antes da gente fazer o exame.

Corte para outro depoimento:

- Aí é diferente, eu acho que é isso o que deve mudar, do médico deixar de lado essa pose (ela arqueia os ombros) porque ele é um profissional, porque ele estudou, porque ele está todo de branco, assim só vai meter medo nas pessoas.

Corte para a fala de outra mulher:

- ... se continuar assim, a gente morrendo de medo não vai prá frente , não... Tem que ter coragem, mesmo, tem que enfrentar.

Corte.

Seqüência 3: (S3)

Primeiro plano de uma senhora idosa falando e gesticulando. Enquadra-se primeiro ela falando e depois se focaliza o detalhe das suas mãos com o punho fechado . A câmera volta-se novamente para o seu rosto:

- Agora, se botar mesmo prá frente, com fé em Deus, se (....) fizer uma reclamação, aí a pessoa vence o que quer!

Vemos seu rosto em close com um sorriso e sobe o som da música que estava de fundo, encerrando o vídeo. 
A partir do depoimento de uma das mulheres na S2 colocando que se conhece muito pouco por dentro, podemos notar que está colocada uma oposição relativa ao interior e o exterior do corpo. O exterior é a aparência, a forma do corpo que os outros vêem; o interior seria o que não é visto, algo que não se conhece, local de onde vêm as dores, a parte que é de domínio da medicina, aquilo que é necessário ser revelado e conhecido para ser integrado no corpo como um todo. Aquilo que vem do interior, as dores por exemplo, são sentidas, mas é colocado que é necessário um maior conhecimento, uma maior conscientização dos processos do corpo para nomeá-las. O conhecimento do corpo, proposto por grupos feministas, seria um dos caminhos para esta finalidade. Valoriza-se a necessidade de se ver, se conhecer e de localizar as sensações no corpo. A explicação sobre o funcionamento do corpo não deveria ser um monopólio dos profissionais de saúde. Refletindo um pouco sobre esta questão vemos que é uma busca legítima, que tem uma finalidade educativa e conscientizadora. Porém continua a ter um sentido que é de certa forma comum à prática médica dominante. A idéia central continua a ser a de espacialização, ou seja, de se buscar identificar os "lugares" das sensações no corpo, identificando-se os órgãos e suas determinadas funções .

FOUCAULT (1984) analisa como se deu a constituição histórica deste tipo de visão, a noção de espacialização da doença como um dos elementos que regem o discurso e a prática clínica. Sabemos que na visão feminista esta forma de ver o corpo não está desvinculada da visão dos condicionamentos sociais e políticos a que ele está submetido. Mas não deixa, porém, de ser influenciado pela perspectiva do corpo como objeto sobre o qual é construído um saber. Num certo sentido remete-se novamente para a visão do corpo como uma soma de partes, refletindo concepções histórica e culturalmente determinadas.

Há uma menção à diferença de tratamento por parte do médico segundo a classe social, que leva a um reforço na atitude autoritária. Uma das mulheres diz que o médico atende de forma diferente os pobres dos ricos, porque estes "têm muito mais explicação para os médicos". Esta 
diferenciação é apontada por BOLTANSKI (1979) que, a partir de pesquisa realizada, afirma: "As explicações dadas pelo médico ao doente variam, efetivamente, em função da classe social do paciente; os médicos, em geral, não dão longas explicações senão àqueles que julgam "bastante evoluídos para compreender o que vai Ihes ser explicado. "(p.44). Segundo o autor esta postura não decorre apenas das barreiras lingüísticas entre as classes, mas é uma forma de demarcar um poder sobre as classes populares. $\mathrm{O}$ exercício deste poder, representado por atitudes autoritárias e constrangedoras, é sentido pelas mulheres ( $\mathrm{S} 1$ e S2), e do qual elas buscam se libertar ao se colocarem como sujeitos de sua história ("quem tem que brigar mesmo sou eu!"). Vemos nestas cenas do grupo a configuração dos três corpos, o cruzamento das dimensões existencial, social e política, sendo que a representação do corpo político é dominante.

Uma das mulheres entrevistadas diz que a falta de atenção por parte dos médicos também acontece com pessoas de classe social mais elevada. Relata então sua experiência sobre uma consulta médica, da qual ela saiu sem saber exatamente o que tinha, de onde vinha a dor que ela sentia. Pelo o que ela coloca podemos perceber que existe uma necessidade de saber mais, de localizar as sensações, para dar maior concretude ao que se sente no corpo. É como se, a partir da delimitação do local da dor, ela se tornasse finalmente concreta; sem isto há uma sensação de irrealidade. Soma-se a isso o fato de que as partes do corpo que doem nem sempre são visíveis, colaborando para ampliar esta sensação. A herança cultural que nos leva a considerar como reais apenas as coisas que são visíveis e concretas, faz com que os indivíduos acabem por ter uma necessidade de confirmação do que sentem. A compreensão é buscada pelo conhecimento intelectual do corpo.

Vemos neste material que existe novamente uma referência ao espelho, apesar dele não aparecer como objeto em nenhuma cena. Na S2 uma das mulheres cita o trabalho de uma médica que dá o espelho para a paciente se ver. Segundo CHEVALIER (1997) o espelho simboliza, em várias culturas, a sabedoria e o conhecimento, pois ele revela a verdade. 
Como é mostrado também no vídeo Denise, esta é uma das técnicas utilizadas por grupos de mulheres. $\mathrm{O}$ movimento feminista coloca que $\mathrm{o}$ desconhecimento da mulher sobre seu corpo gera uma alienação e o processo de conhecimento visa gerar uma apropriação do mesmo, visando tornar a mulher sujeito de sua própria história, rompendo o isolamento do mundo doméstico (ALVES E PITANGUY 1985; OLIVEIRA,1988). Esta postura e as lutas daí decorrentes são de fundamental importância para o corpo político e um dos instrumentos de resistência ao poder imposto pela sociedade patriarcal sobre os corpos das mulheres nos processos de reprodução, sexualidade, etc. Normalmente o corpo da mulher é visto pela sociedade como algo que remete à natureza, pois é considerada a principal responsável pela continuidade da espécie. Apontar a interferência dos condicionamentos sociais sobre ele é de fundamental importância para desnaturalizar esta concepções. Traz também reflexões sobre a relação entre corpo individual/ existencial e o corpo político. Os depoimentos neste vídeo seriam uma forma de fazer esta ligação do individual com o coletivo. (ver também MELLO, 1993, citada na pg.5 deste trabalho). De acordo com OLIVEIRA (1988) "a descoberta da política na primeira pessoa pelo movimento feminista tem mostrado a importância do pessoal e do subjetivo na necessidade de uma política geral (....) é a conexão entre o modo de vida e a luta pela transformação social." (p. 92-93) Esta transformação passa, segundo a abordagem do vídeo, por uma melhoria na qualidade da atenção médica e por uma revisão do conteúdo autoritário da relação médicopaciente.

Os espaços de resistência seriam tanto o espaço público quanto o privado, mas os espaços onde foram gravadas a maior parte das cenas são públicos, nas filas de um hospital, no bairro onde o grupo de mulheres discute seus problemas, etc.(Figuras 9 e 10). A escolha por este tipo de configuração dos cenários escolhidos não é gratuita, pode ser uma forma de reforçar a ação na esfera do público. 


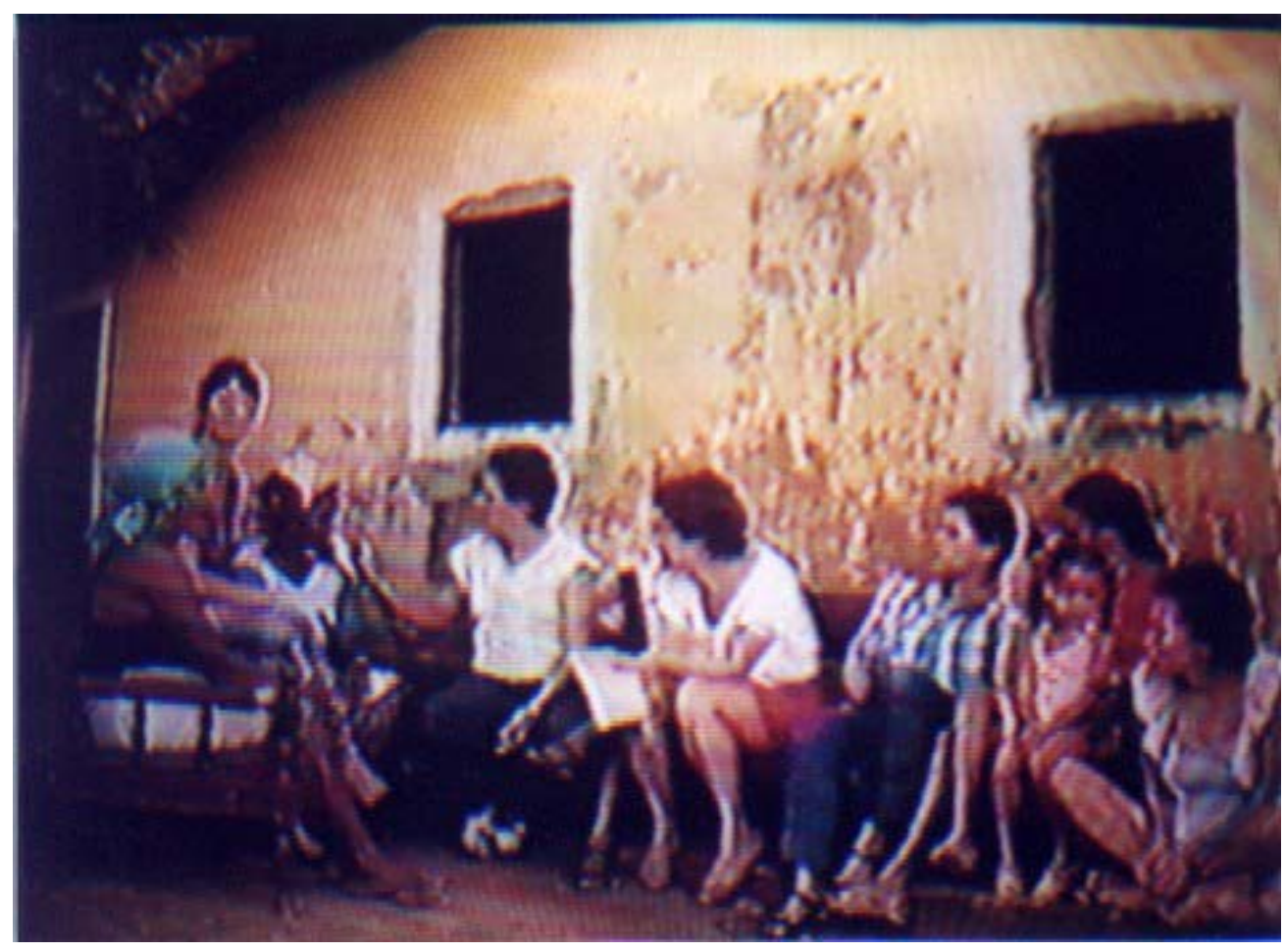

Figura 9

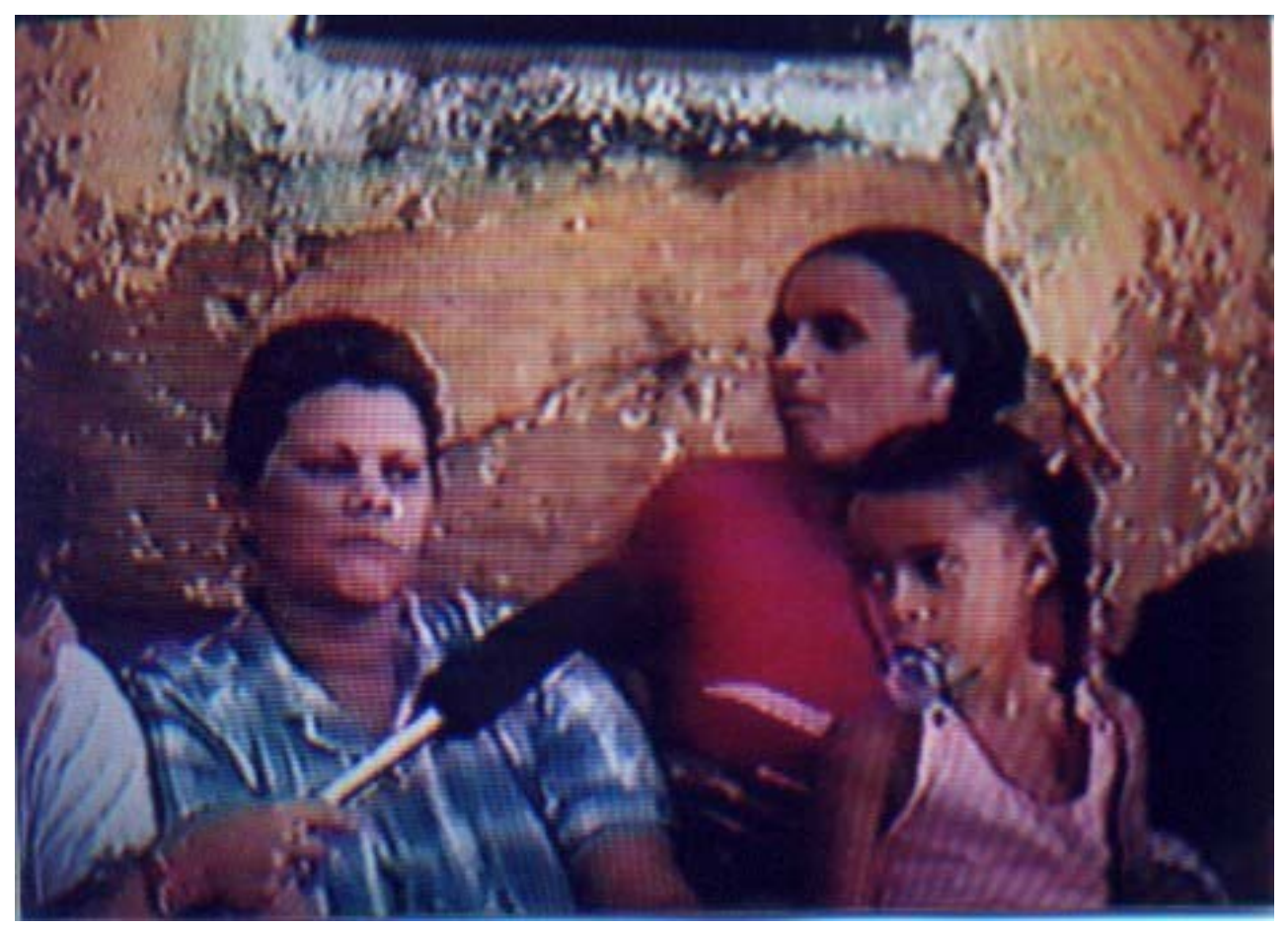

Figura 10

$\mathrm{Na}$ seqüência final (S3) a imagem da senhora idosa na fila é enquadrada em primeiro plano, sendo que depois vemos sua mão com 
os punhos fechados enquadrada em detalhe, simbolizando a ação, a força e a luta pelos direitos. É uma imagem que passa a idéia e a emoção da resistência. (Figuras 11 e 12)

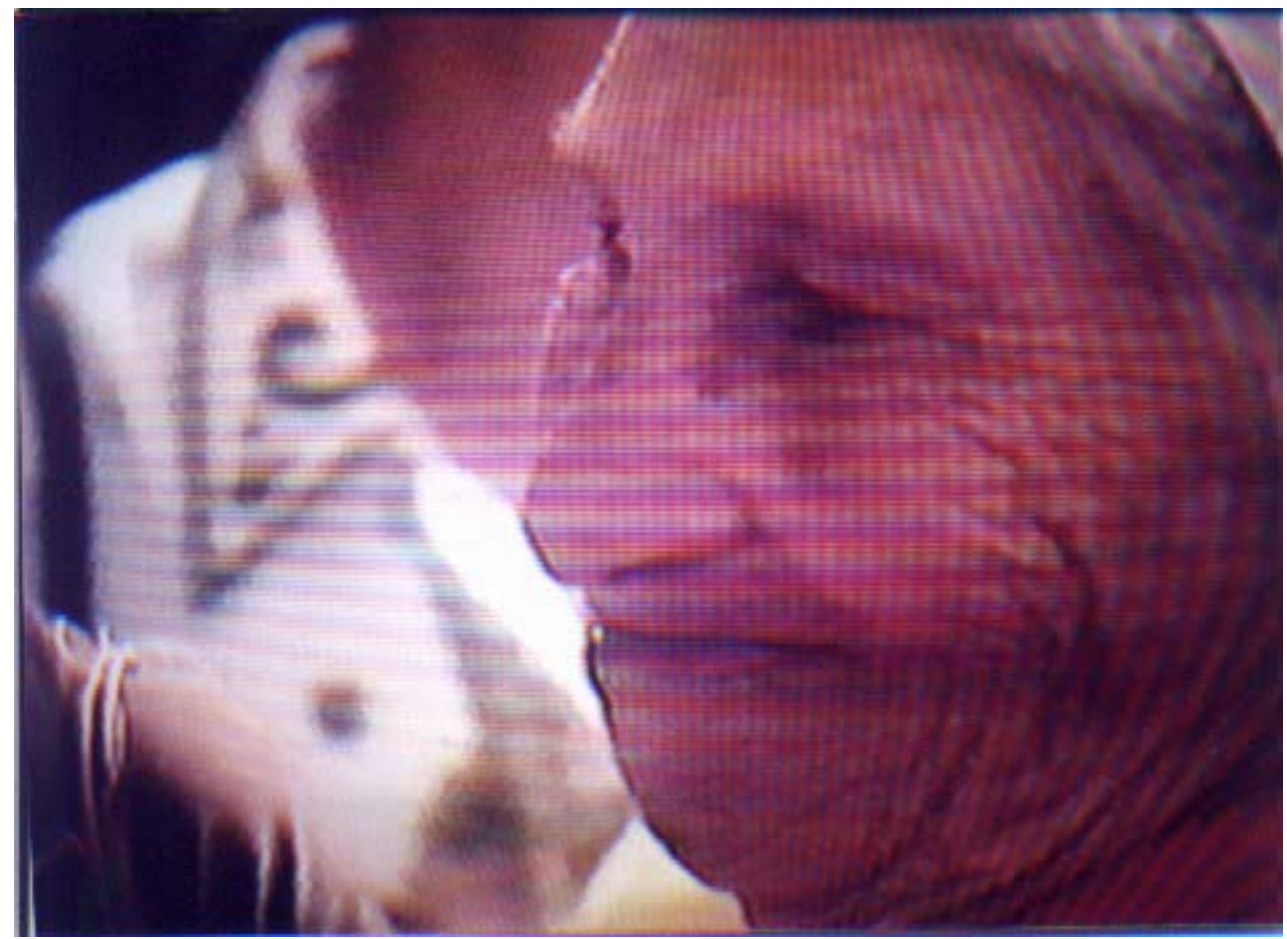

Figura 11

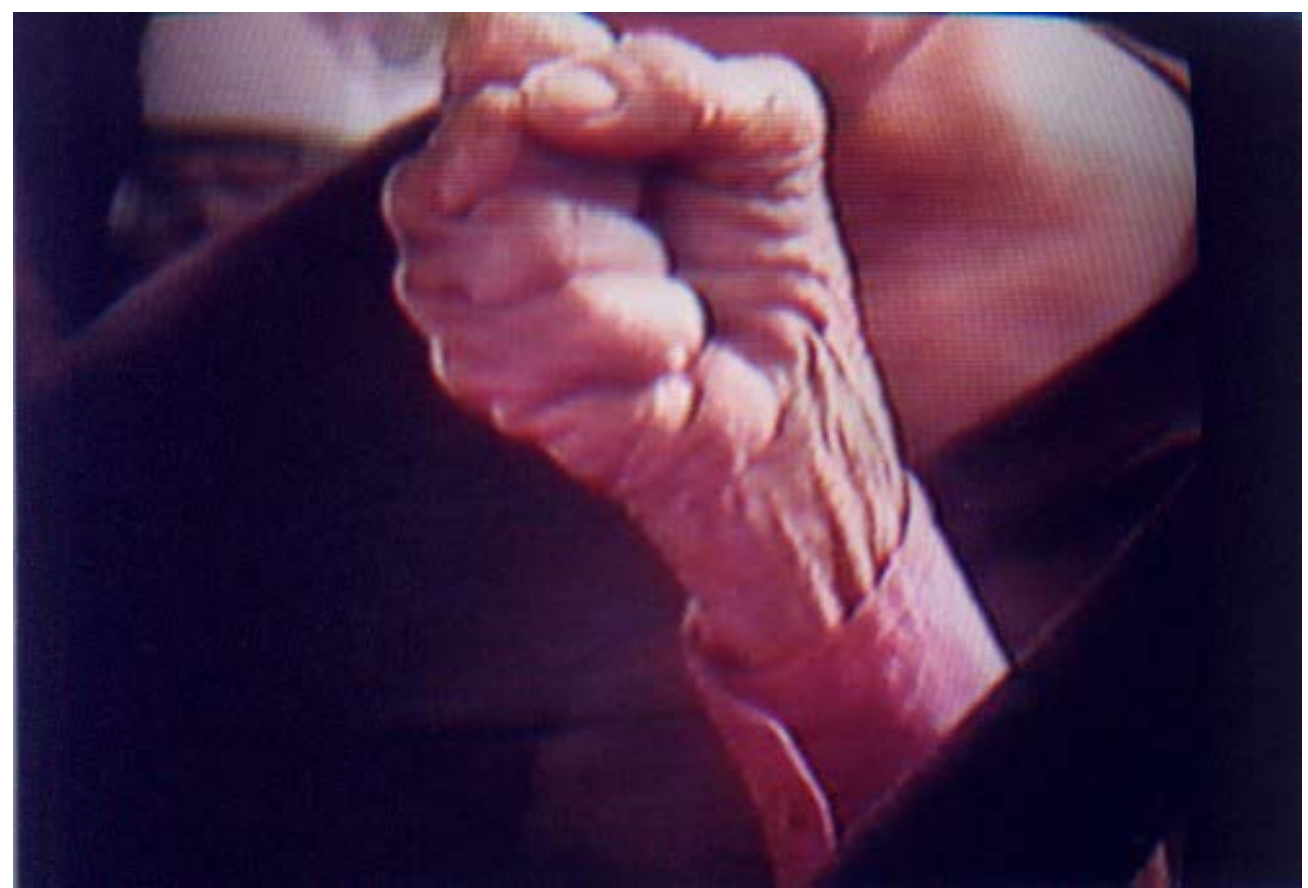

Figura 12 
São entrevistadas duas profissionais de saúde, sendo que a fala de uma delas a respeito da prevenção do câncer é interessante para ver como o sistema de saúde lida com a prevenção de doenças, fragmentando as ações. A médica coloca que, no momento de produção do vídeo, nos serviços de saúde, somente é realizada a prevenção do câncer de colo do útero, e não o de câncer de mama. Apesar das propostas de atenção integral à saúde vemos que o sistema incorpora aos poucos, provavelmente por questões estruturais (falta de profissionais, falta de equipamentos, materiais,etc. ) a atenção a partes do corpo, revelando tanto uma falta de integração das instituições de saúde, quanto uma concepção de corpo que não supõe uma totalidade integrada. A concepção do corpo como máquina, um corpo fragmentado, reflete-se na forma de atenção à saúde. 


\section{Vídeo 3: Amamentação: vamos recuperar esta prática?}

Sinopse: Documentário que apresenta e discute as principais questões referentes ao aleitamento materno : papel da mãe, da família, da sociedade, necessidade de apoio dos serviços de saúde, alojamento conjunto, etc, visando estimular o aleitamento.

Seqüência 1: Abertura do vídeo (S1)

Fundo musical: "...é feito um bichinho no sol de manhã..."/ panorâmica: câmera passeia por um parque com muito verde/ corte para mãe amamentando e acariciando um bebê/ fecha com um close do bebê/ close da mãe/ corte/ close de um outro bebê, abrindo para a imagem da mãe sorrindo/ sobrepõe o título do vídeo/ voz em off :"o leite materno preenche as necessidades da criança até o $6^{\circ}$ mês de vida; o desmame precoce deixa a criança vulnerável a infecções e à desnutrição na fase da vida em que ela mais precisa de proteção."/ fecha imagem no bebê/ corte/ imagem em $1^{\circ}$ plano de uma mãe pressionando o bico do seio para sair o leite; fecha no close do seio e do rosto da mãe/ em $1^{\circ}$ plano o seio e o bebê com a mão de uma outra pessoa (provavelmente um profissional de saúde) pressionando o seio para sair leite / em off: "o leite materno contém todos os nutrientes necessários ao crescimento e desenvolvimento; todo bebê que mama no peito ganha proteção contra doença pela presença de fatores antiinfecciosos no leite materno e que protegem a criança nesta fase tão importante"

Seqüência 2: Final (S2)

Apresentação em imagens com orientações sobre ações de incentivo ao aleitamento materno e orientações alimentares para o desmame / corte/ enquadramento em primeiro plano de um palmeira ocupando a tela com o verde da natureza/ imagem dos créditos e ficha técnica do vídeo/ fundo 
musical igual ao do início "...água, terra, fogo e ar..."/ detalhes do parque, árvores, construção antiga, plano geral do parque/ zoom fechando / fusão com cartaz com imagem de uma mãe amamentando com os dizeres "mãe e filho têm esse direito"/ fim

No início da S1 a ambientação é em um cenário natural, em um parque, sendo que o enquadramento utilizado faz com que a cor verde das árvores preencha o quadro da tela.(Figura 13)

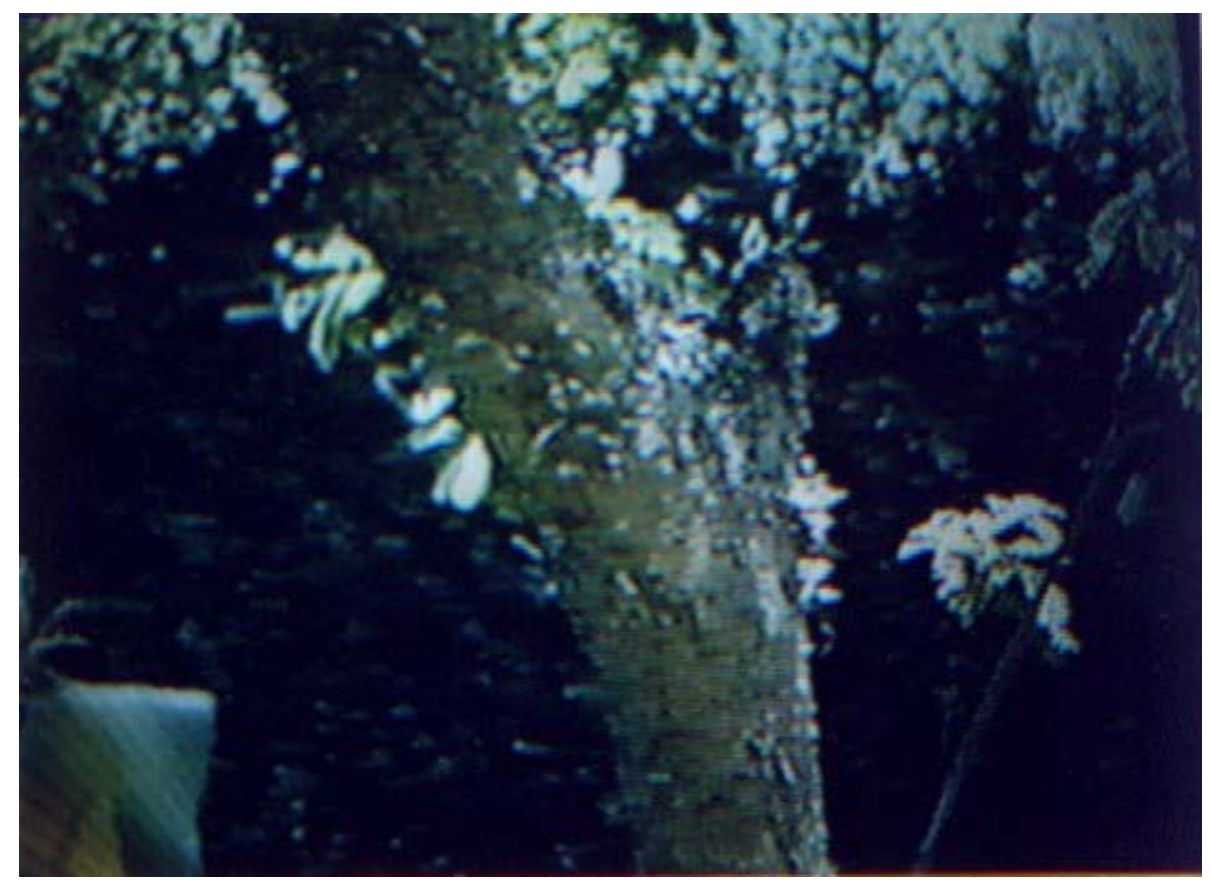

Figura 13

Com uma panorâmica do parque, a música falando da criança como "um bichinho" e os ruídos de pássaros, compõem um plano em que se reforça a idéia do corpo da criança, e da mãe, como algo da natureza. Nesta apresentação remete-se para a oposição natureza/ cultura, buscando-se reforçar e resgatar o primeiro pólo. Em outra seqüencia temos, por ex., a fala de uma mãe questionando qual espécie se separa de seu filhote, remetendo novamente para esta dicotomia. Em outras seqüências surgem reflexões sobre o modo com que a nossa cultura lida com a questão. Coloca-se, como proposta, que se busque "preparar a sociedade para uma maternidade mais 
natural", para combater a desnutrição, remetendo novamente à mesma dicotomia. Nesse sentido coloca-se o papel dos serviços de saúde em resgatar uma prática mais natural.

Com relação ao corpo social e político, vemos a dicotomia indivíduo $\mathrm{x}$ sociedade ao abordar-se os direitos da mãe e várias dificuldades apontadas para defendê-lo.

No depoimento de uma mãe é levantada uma questão que aponta também para a configuração do corpo social e para a dicotomia parte $\mathrm{x}$ todo, que é a de que no pré-natal médicos não se preocupam em preparar para o aleitamento, como se esta parte do corpo da mulher não fizesse parte do processo da maternidade. Desta forma as ações de saúde acabam por restringir-se a partes do corpo, dissociando-se da atenção ao corpo como um todo. Podemos analisar esta questão a partir da visão sobre o processo de configuração do corpo como máquina. Privilegia-se a parte do corpo - como se fosse a parte de uma engrenagem - sobre a qual a atuação do profissional deve se concentrar, pois é a parte central do processo. Segundo Martin, citada por STRATHERN (1996), de acordo com a visão do corpo como máquina, o útero, no contexto da reprodução, é a principal parte (p.149).

Apesar de não ser explicitada no vídeo, esta abordagem distorcida pode também remeter a outra dicotomia, a do corpo/mente, ou seja, cuidase do corpo físico e não se leva em conta o corpo emocional. O vídeo fala da falta de atenção do médico com a preparação da mulher para o aleitamento, além da falta de esclarecimentos e acompanhamento quando surgem as dificuldades na amamentação; é como se isto não fizesse parte do processo todo. Esta problemática deve ser melhor investigada, ou seja, quais as razões pelas quais os profissionais da área clínica resistem, de alguma forma, a abordar esta questão ou a abordam de uma forma enviesada, como "obrigação" da mãe, culpabilizando a mulher quando isso não ocorre, mesmo sabendo que ela é importantíssima. 
Utilizam-se imagens em primeiro plano de mães e filhos no ato da amamentação São imagens tocantes e que podem colaborar para sensibilizar sobre o tema. (Figuras 14 e 15)

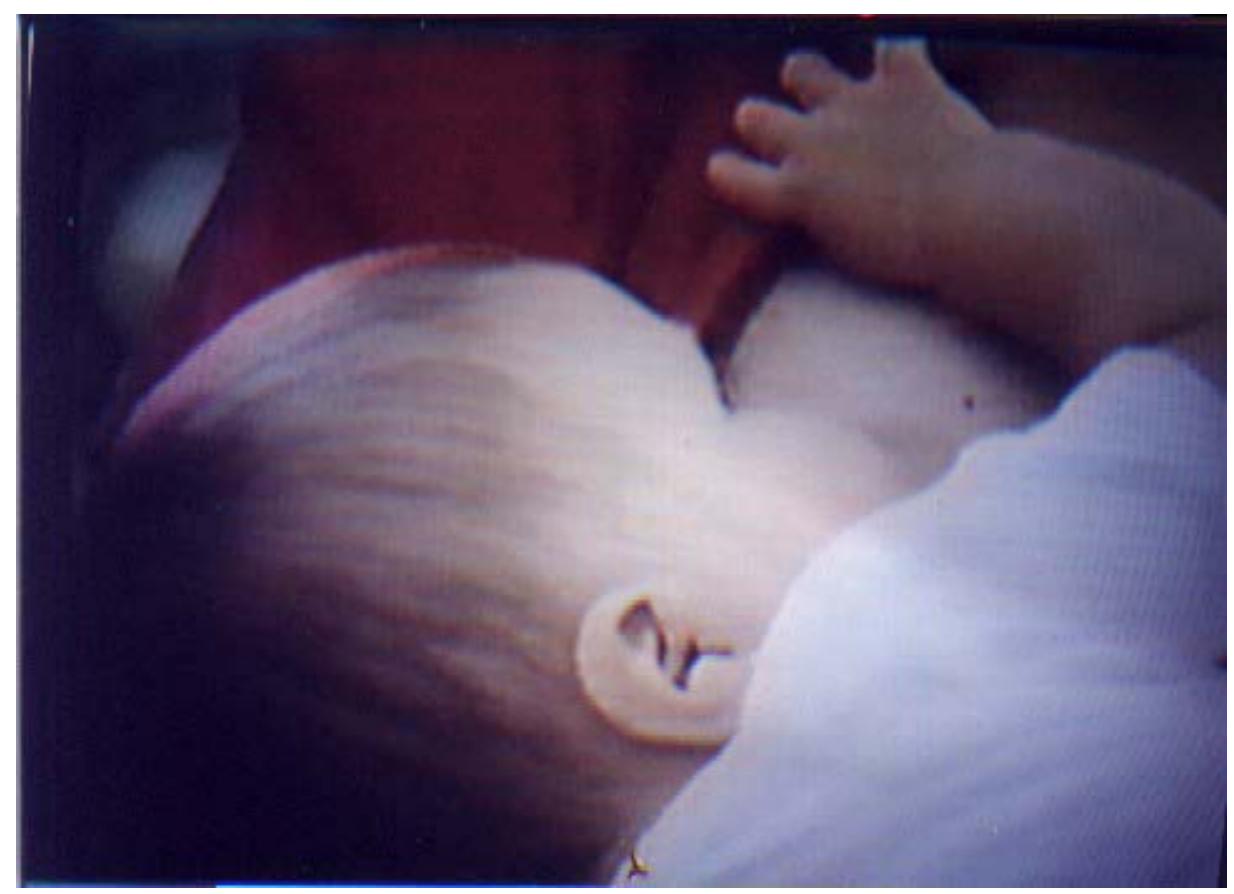

Figura 14

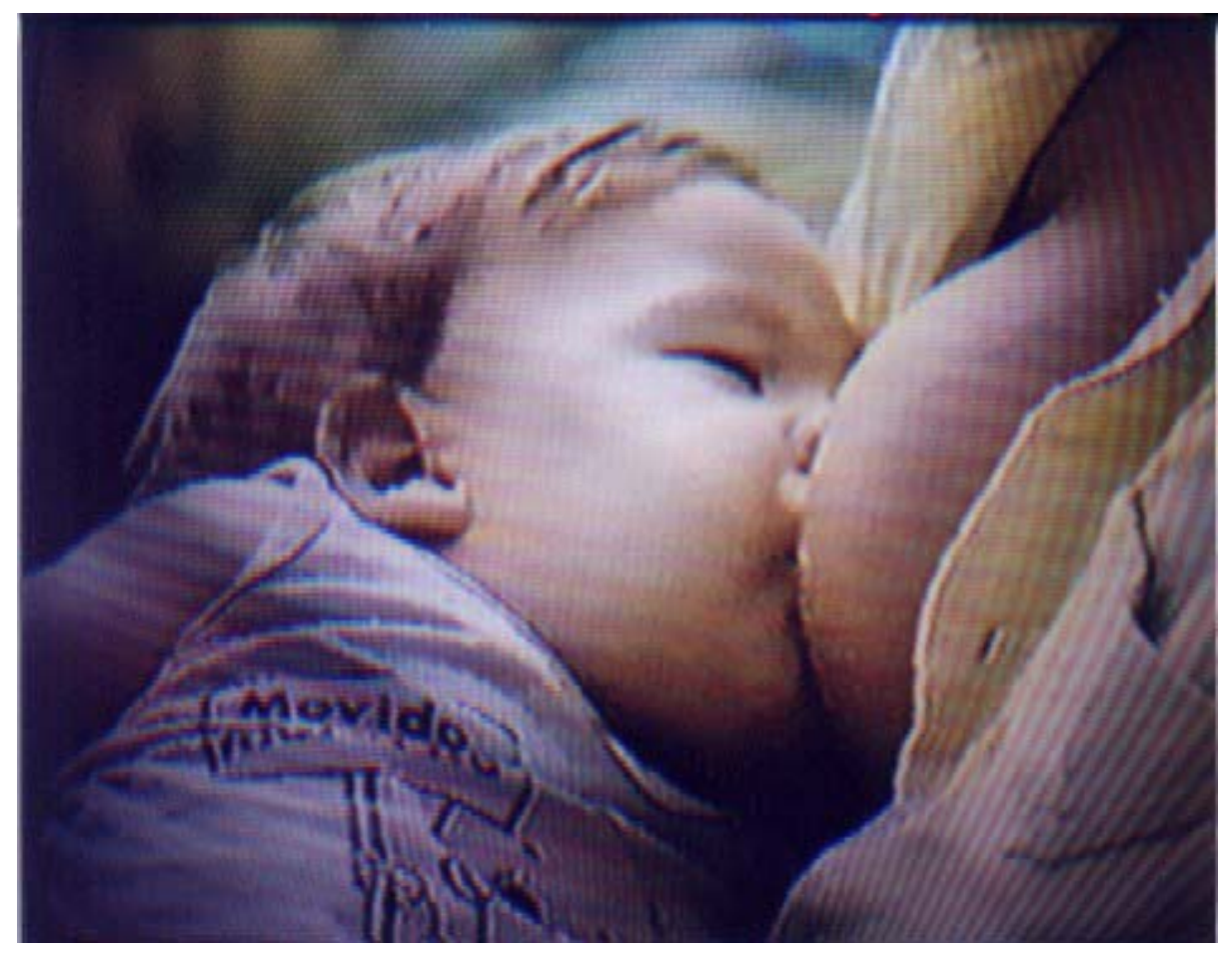

Figura 15 
A voz em "off", com um discurso impessoal, gera um certo distanciamento. O tom da voz, com uma entonação neutra, sem demonstrar emoção, pode gerar uma quebra no envolvimento emocional do espectador. Geralmente quando se escuta uma voz imagina-se o corpo; no momento em que se força uma impessoalidade é como se a voz não tivesse corpo. Pode ser que isto cause uma dificuldade na interação do espectador com aquilo que é exibido, pelo menos ao nível de seu envolvimento emocional com a questão. Segundo BETTON (1987):

A simples audição de uma voz pode dar uma imagem incrivelmente exata da maior parte das características físicas e mentais de uma pessoa, e particularmente de um ator. O poder de convencimento da palavra humana não está unicamente nas palavras pronunciadas e nas idéias que estas sugerem: ele reside também no próprio som da voz, e esta não somente tem um poder de sugestão, mas também um valor psicológico incontestável (ele exalta a emotividade). $\mathrm{Na}$ verdade, a entonação, o ritmo e o timbre são mais importantes que a sintaxe (BETTON,1987,p.44).

O autor cita Merleau-Ponty para afirmar que "a prodigalidade ou avareza de palavras, sua plenitude, ou seu vazio, sua exatidão ou sua afetação fazem sentir a essência de uma personagem de forma mais segura do que muitas descrições" (BETTON ,1987,p.44)

O vídeo, ao que tudo indica, visa de preferência um público de estudantes e profissionais de saúde, apesar de ser utilizado também com os usuários do serviço de saúde. Porém, o conteúdo é centrado mais em discutir os fatores que levaram nossa sociedade ao abandono do aleitamento materno e a importância da volta desta prática como fator de proteção à saúde física e emocional da criança. O vídeo fala principalmente do ponto de vista do profissional. As discussões propostas pelo grupo "Amigas do peito" que dão os seus depoimentos dão uma tonalidade mais emocional ao tema. É importante este contraponto, pois o vídeo não se 
transforma totalmente no modelo de vídeo "educativo / instrutivo" que fornece respostas para tudo; não, ele coloca questionamentos. São as falas destas mulheres - em alguns casos falando na primeira pessoa - que colocam a relação maternidade-trabalho, a importância da participação do homem no processo, as dificuldades e prazeres, além dos problemas quanto à atuação do médico no acompanhamento pré-natal. O corpo do homem, no papel de pai, está ausente fisicamente, mas está presente nas falas das mulheres que discutem a questão.

Com relação à oposição entre o natural e o social, pensamos que ela possa estar também na origem da concepção medicalizada do corpo. A idéia de um corpo biológico (natural) que é passível de controle é a idéia de corpo para muitos profissionais, sobretudo os médicos, sendo o corpo visto como um objeto no qual se intervém. A herança histórica das concepções sobre o corpo da mulher nos informa que ele é visto como algo da natureza e que, ao se intervir nele, realiza-se um ato da cultura. A medicalização do corpo já é um tipo de controle social. Isto configura um corpo que não é mais só biológico, se afastando de sua natureza. Ao se pretender "restaurar" a natureza do corpo nota-se uma busca que parte de um pressuposto falso, pois não existe esta "natureza" do corpo como um estado "puro" ao qual se possa retornar. A luta pelo alojamento conjunto, colocada no vídeo, é legítima no sentido de que é uma busca no sentido de humanizar a atenção à saúde, não no sentido de que vai torná-la mais natural e mais de acordo com a espécie (biológica) humana. 


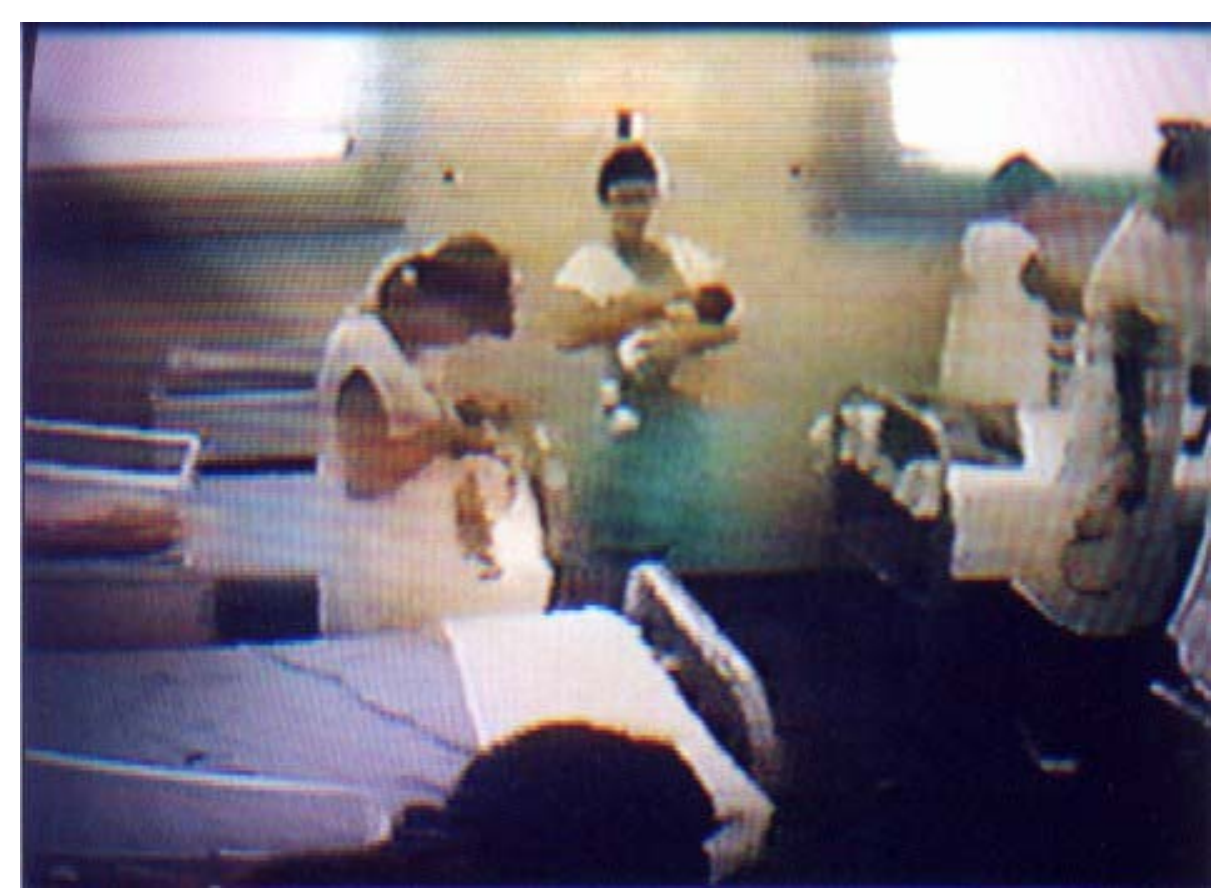

Figura 16 


\section{Vídeo 4: Denise.}

Sinopse: Ficção que conta a história de Denise, mulher de baixa renda moradora de um bairro periférico de uma cidade do Nordeste, frente a problemas como concepção, machismo, trabalho, sexualidade, creches e assistência médica. Apresenta as desvantagens de se fazer a esterilização e as vantagens de usar o diafragma.

\section{Seqüência 1: (S1)}

Imagem de uma reunião do grupo de saúde com música de fundo fechando o enquadramento em uma das participantes. Voz em "off" : "Eu acho que a única pessoa que lutava um mínimo pelos direitos da mulher era eu, mas vi que não, que essas mulheres tavam pensando muito..."

Imagem das mulheres falando, close do rosto de uma delas, detalhes das mãos; close da protagonista / corte para imagem da sua mão / corte/ abre com suas mãos lavando as roupas/ corte/ plano médio da protagonista lavando roupa com o filho brincando/ corte/ ela em frente ao espelho; vemos seu rosto no espelho; som de fundo.

\section{Seqüência 2: (S2)}

Cena de novela na televisão; marido sentado assistindo, ela chega, dá um beijo/ corte/ cinzeiro cheio de pontas de cigarro/ corte/ primeiro plano do marido com movimento de câmera de fechamento no seu rosto

\section{Seqüência 3: (S3)}

Reunião do grupo em que as mulheres examinam os órgãos genitais de uma das participantes; voz em "off" como um depoimento: "quando o médico abria para ver a gente eu pensava que a mão ia lá dentro e as partes, o intestino, os rins, era tudo à vista, e a gente olhando a gente via tudo, como quando a gente abre uma galinha, e agora a gente sabe o que ele vai ver"; imagem da vagina com o espéculo e a imagem vista no espelho; voz em "off" : "eu imaginava mais vermelho, que tivesse sangue, com mais ação, 
mais violência, quando vi foi uma coisa tão simples" / corte para protagonista andando, voltando para casa; voz em "off" : "uma experiência muito linda".

\section{Seqüência 4: (S4)}

Protagonista descendo escadaria de onde mora, com o filho no colo; colocao no chão, dá um beijo/ corte/ close de uma mulher olhando com curiosidade e certa crítica/ áudio: música com a letra "se o povo falar, falar, nem ligue, nem ligue, deixa o povo falar..." / corte para a protagonista se despedindo da irmã com quem ela deixou o filho/ corte para primeiro plano de mulheres falando, como se estivessem fofocando/ ruídos de falas misturadas/ close de uma das mulheres com expressão de recriminação/ corte/ detalhes da roupa da personagem: uma flor vermelha aplicada na saia preta e meia vermelha de rede, decote da blusa, sandália preta / corte/ imagem desfocada que vai sendo focalizada aparecendo a protagonista em primeiro plano/ corte para ela sendo vista, com enquadramento de baixo para cima, descendo a escadaria/ som de fundo com ruídos simbolizando a fala da vizinhança/ corte para close de mulheres olhando com reprovação a personagem / detalhe dos pés terminando de descer a escada.

Em uma das seqüências iniciais vemos uma mulher, representante de um médico , buscando "vender" a laqueadura para a protagonista, apontando assim para a problemática dos serviços médicos enquanto integrante da esfera do consumo, como uma mercadoria. A música utilizada, do filme / desenho "A pantera cor de rosa" , vai conduzindo um clima de mistério. A protagonista recebe a mulher com desconfiança e suspeita, reação compreensível face ao conteúdo de manipulação desta ação. É interessante a analogia que faz então a protagonista dizendo que fazer a laqueadura seria "como tirar os olhos, eu não enxergaria mais!". A ligação entre os olhos e as trompas, a parte baixa com a parte alta do corpo, sinaliza a percepção de que existe uma integração no corpo. Uma ação em uma parte reflete em outra e no corpo como um todo. Apontar isto é importante, pois a força predominante na nossa cultura é a da separação e 
dissociação das partes, configurando um tipo de corpo específico do ponto de vista existencial, social e político. Sob a influência do individualismo os corpos aparecem cada vez mais como partes independentes, fragmentadas, trazendo conseqüências em termos sociais, no sentido da sociedade ser vista como uma soma de partes (RODRIGUES, 1999; SILVA, 1999). Visto desta forma o corpo é muito mais passível de controle social e político, de manipulação.

Em uma das seqüências a protagonista vai a uma consulta médica, pois tem um problema ginecológico. Ela informa ao médico que está usando o diafragma como método anticoncepcional. Ele a desmotiva a usar este método, desconsiderando e desestimulando sua opção. Ele reage de forma semelhante ao que é apontado por BOLTANSKI (1979) quando se refere à conduta do médico em relação aos pacientes que "prestam demasiada atenção a si próprios". Os profissionais tendem, nestas situações, a agir com negação, repreensão, ridicularização.O gesto dele neste momento é de tamborilar os dedos ( visto em plano de detalhe) como estivesse um pouco irritado. Ele diz : "Se a sra quer assim deve saber o que faz... Eu Ihe digo prá pensar bem porque o arrependimento pode chegar tarde! ", carimba uma receita e encerra a consulta. Vemos que há uma direção na escolha do gesto executado pelo médico, é um gesto construído, assim como é intencional a sua focalização em detalhe, com o objetivo de representar uma reação estereotipada. Por se tratar de uma ficção há esta liberdade na construção dos movimentos, diferente dos documentários onde os gestos pelo menos no que diz respeito aos entrevistados- são espontâneos e os recursos que se tem para trabalhá-los limitam-se ao enquadramento e à edição, optando-se por incluí-los ou não, ou combiná-los com outras imagens.

Neste vídeo a postura do homem enquanto companheiro é caracterizada como alienada. Existe um exagero na caracterização, proposital ; é a postura do macho; o não cuidado com a saúde. Pode-se observar na S2 o plano em detalhe dos cigarros e na Figura 17 ele bebendo cerveja. A mulher tem o papel de informá-lo sobre questões 
relativas à reprodução, já que ele não se interessa muito nem está aberto a novidades.

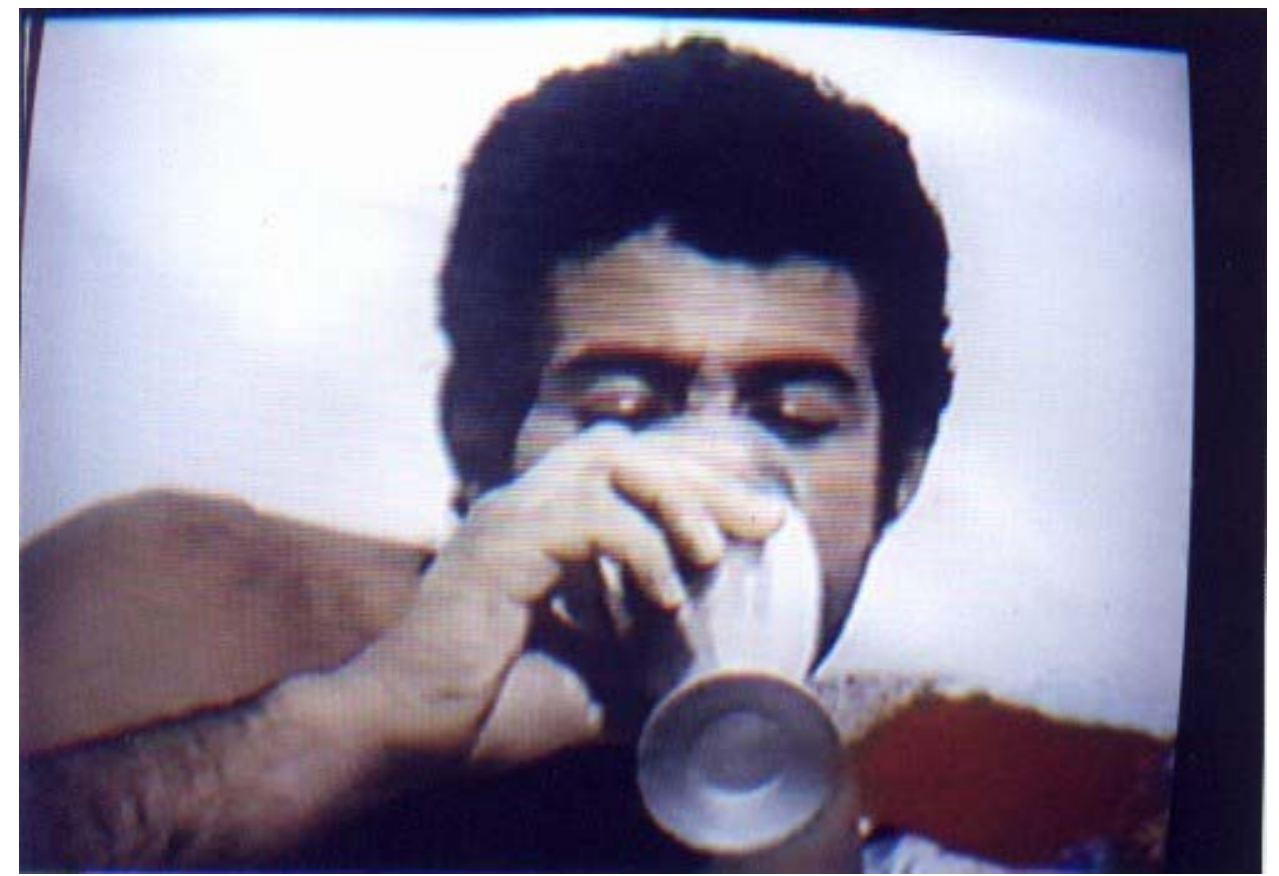

Figura 17

Os vários pontos de vista sobre a questão da mulher, ou seja a visão do marido, da mãe idosa, das vizinhas, do médico, etc., sobre a sexualidade e as opções de vida , criam um panorama amplo de abordagens que podem colaborar para a elaboração de reflexões sobre os conteúdos colocados. Vêse por exemplo a mãe idosa, com a saúde comprometida, condenando as opções da filha , assim como a posição da irmã e das vizinhas com a mesma atitude. É apresentada uma cena em que o médico questiona a opção da mulher pelo diafragma; por outro lado temos a contraposição da coordenadora do grupo de saúde que aponta as várias opções de métodos de planejamento familiar para que as participantes possam decidir. As várias posturas diante das questões abordadas geram uma riqueza ao apontar a diversidade de pontos de vista.

Vemos aparecer novamente neste material o espelho como um objeto de cena. No vídeo 1 ele tem um papel mais importante, mas neste material , adquire um significado semelhante ao que tem no vídeo 2 , ou seja, um instrumento que visa o conhecimento de si e de como é o seu corpo . Na S1 
e em outra seqüência no final do vídeo (Figura 18) a personagem se olha no espelho como se buscasse se reconhecer. Na S3 vemos novamente o uso do espelho de acordo com o que foi citado no vídeo 2, ou seja, como um instrumento para o conhecimento do corpo, estando de acordo com o papel que este conhecimento pode desempenhar na libertação da mulher.

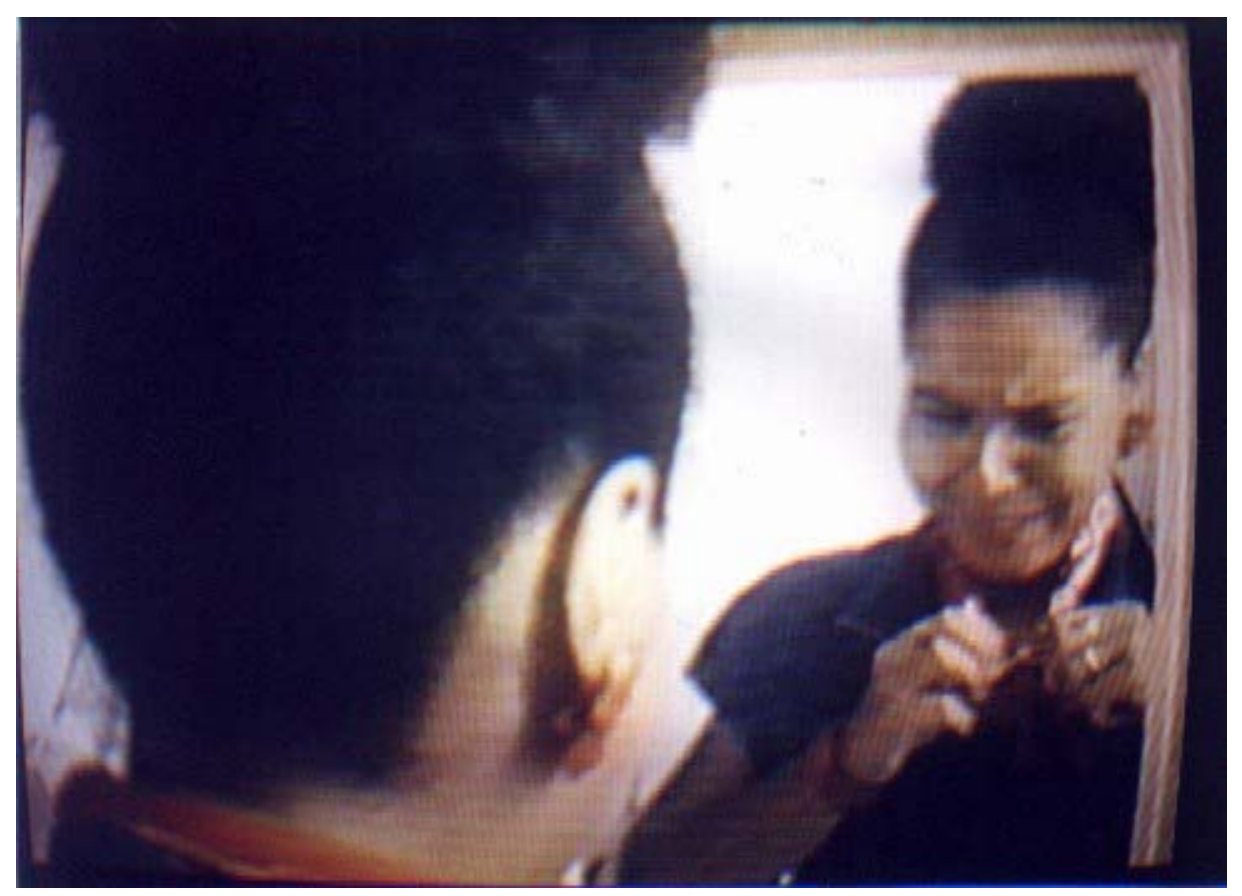

Figura 18

Neste vídeo, apesar da narrativa ser estruturada na trajetória de um indivíduo, a protagonista circula em espaços públicos aparecendo inserida em contextos que congregam outras pessoas de fora do mundo familiar e doméstico (a feira, o ambulatório, o grupo de mulheres). É uma abordagem que busca integrar o mundo privado e o público, o individual e o coletivo, inclusive nos espaços cenográficos. É uma opção de linguagem diferente dos vídeos 2 e 5. A importância do espaço coletivo de reflexão (o grupo de saúde) é fundamental para a protagonista compreender e se posicionar na sua vida privada e nas situações em que vivencia o poder exercido sobre seu corpo.

Neste material existe um trabalho com as várias dimensões temporais. Em uma cena a protagonista se recorda de uma sensação de medo frente aos homens quando ela era criança. Em outro momento, ela devaneia, 
imaginando o futuro, vendo-se trabalhando e vivendo uma cena de paixão com outro homem. Nesta cena ela está deitada sozinha, na posição horizontal, passiva . Esta passividade configura um contexto de irrealidade, de sonho, que, porém, mostra os desejos que a movem, ou seja, a busca do prazer e da realização como um ser ativo no mundo. Ë a busca da concretização dos sonhos na realidade. Esta abordagem propicia com que se faça um contraponto entre a posição passiva da mulher - a mais comume a possibilidade de uma postura mais ativa.

Em S1 existe uma dissociação entre a voz de quem dá o depoimento e as imagens apresentadas, que são do grupo. A fala não aparece com um corpo específico, mas nós podemos até imaginá-lo pelas características da voz. Como a fala tem emoção é como se tivesse um corpo, atraindo a atenção para o conteúdo da mensagem. Durante o depoimento podemos como que passear pelas imagens, sem centrar em nenhuma delas. As imagens servem para descrever um ambiente, um contexto, e ao inserir detalhes colaboram para enriquecer essa descrição .

O trabalho educativo desenvolvido no grupo de saúde (S1 e S3) propõe o autoconhecimento (Figuras 19 e 20) do corpo pelas mulheres. Elas são convidadas a se observar, a se tocar, e, em outros momentos mostrados em outras seqüências, a se movimentar balançando os quadris, soltar o corpo relaxando-o e vivenciando um trabalho de conscientização corporal. 


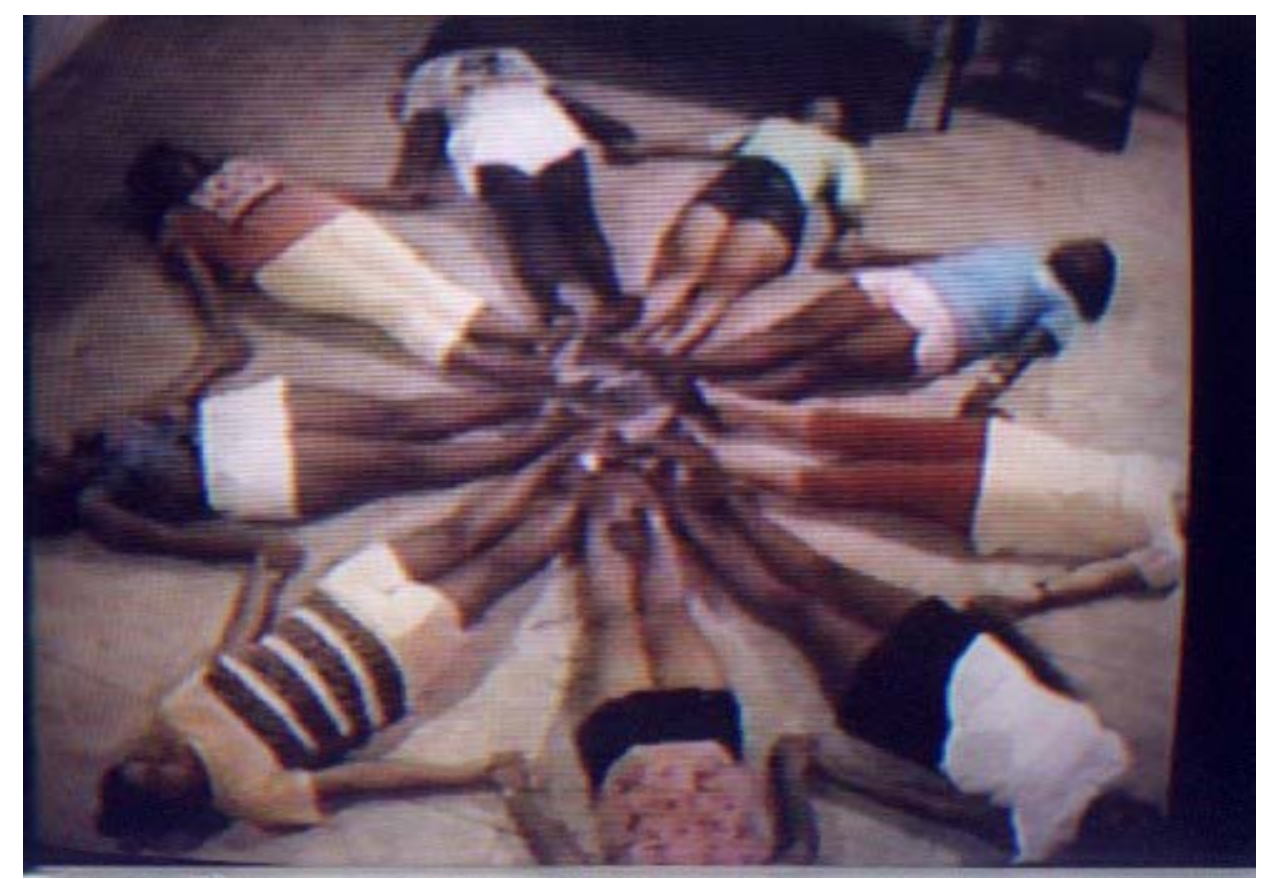

Figura 19

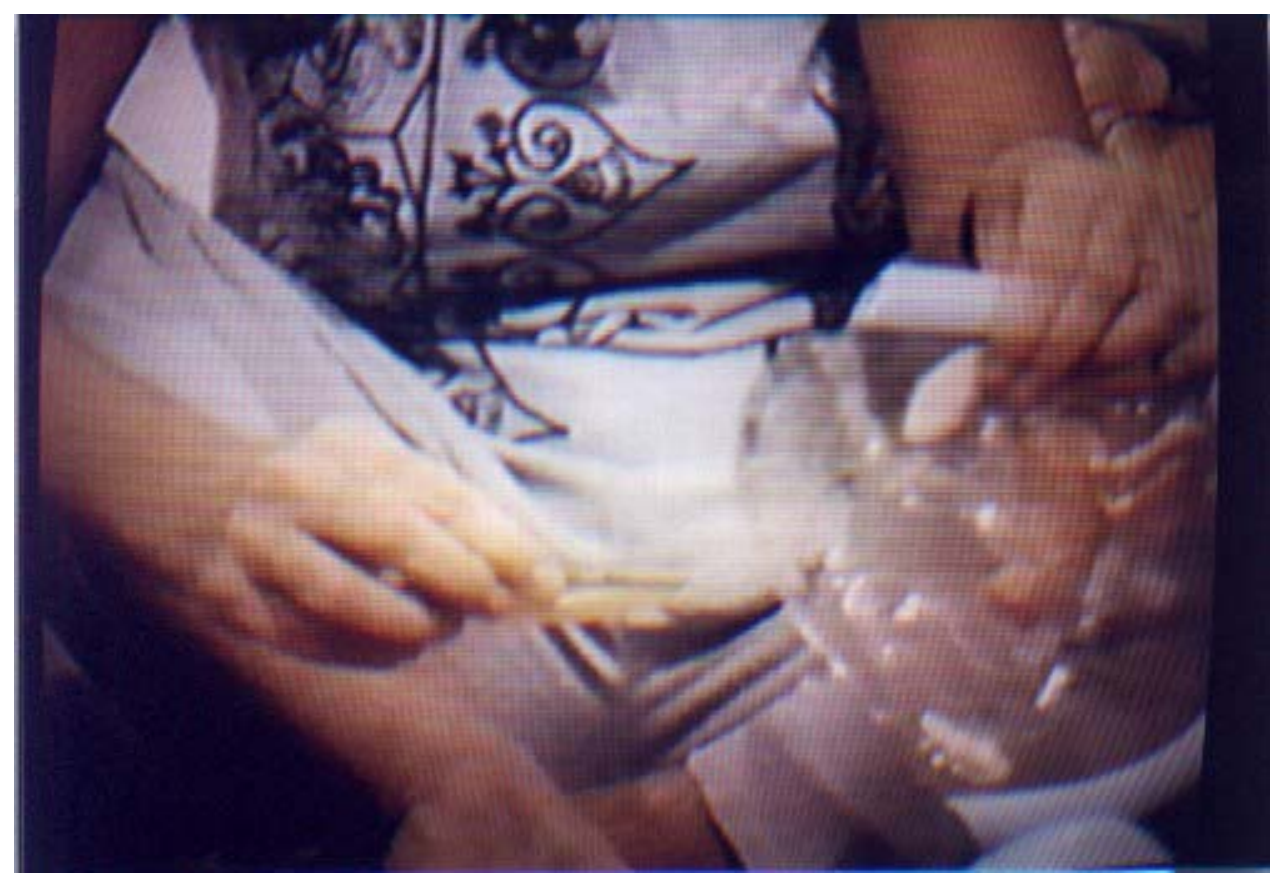

Figura 20

Numa cena em que está em casa a protagonista dança em frente ao espelho, balançando os quadris, exercitando o que aprendeu no grupo.Coloca-se em evidência, nesses momentos, a importância da percepção do corpo como um todo, incluindo as "partes baixas", que normalmente são um tabu. Tocar nestas partes do corpo, movimentá-las 
com liberdade, são vistas pela sociedade como uma transgressão às normas. A estrutura social imprime sua marca sobre os indivíduos através da educação das necessidades e atividades corporais (MAUSS, 1974). Conhecer e apropriar-se do corpo, revertendo a repressão dos movimentos, é visto, pelo ponto de vista do vídeo, como um passo em direção ao processo de libertação da mulher. 


\section{Vídeo 5: Mancha de Batom.}

Sinopse: A partir da descoberta de uma mancha de batom na camisa do marido, tem início uma ficção contando a história do relacionamento de uma dona de casa com um marido machista, que se nega a usar camisinha. Faz um alerta sobre a importância do uso de preservativo na prevenção da AIDS e doenças venéreas.

\section{Seqüência 1: (S1)}

Vemos Lucilene, a dona de casa protagonista do vídeo, em plano médio, apoiada na vassoura e depois continuando a varrer a casa. Ela reflete e fala para o espectador:

- E essa tal de Aids? (Escuta-se o som que é um ruído de um bipe, um alarme.) Será que a gente pega no banheiro? Isso não é doença de transviado? É , o Adelson ( o marido) falou que com ele não vai ter problema nunca, ele não vai pegar isso não, sabe, porque ele é muito macho! Ele fala: "sou macho, sou macho, sou macho, isso aí não pega, não pega! "

A câmera enquadra um pequeno porta retrato com a foto do Adelson. A partir da foto a imagem entra em movimento e o vemos em close falando para o espectador:

- Macho mesmo, esse negócio de aids é coisa de viado. Homem que é homem não pega dessas coisas não. E se pegar não morre. Eu já tive ferida no pau, ficava pingando pus, tive verruga, dor prá mijar... Ó, tô aqui, inteiraço! Agora vou morrer de aids?

Vemos Lucilene sentando no sofá falando se dirigindo a ele:

- Mas não é isso que fala na televisão, não.

- E você acredita em tudo que escuta na televisão, mulher? O seu problema, Lucilene, é que você vê muita novela.

— Há, há! E você também não vê,é?

— Eu vejo porque sou obrigado, né?Você não assiste outra coisa. Eu tô lá, eu ... 
- Mas não foi na novela que eu ouvi que essa Aids não dá só em gay não.

— É, dá em drogados também.

- Mas tem mais viu...

- Hei, pera, pera, peraí, Lucilene. Cê tá achando que sabe tudo é? Vai me dá aula agora? Onde foi que cê estudou, hein?

- Na mesma escola que você, viu, na escola da vida. Esse homem não me escuta e também não me deixa falar. O Antenor morreu, a família disse que foi de pneumonia, mas todo mundo sabe que foi de aids. Ele não era bicha e também não era drogado ...

Olha para o alto e pensa:

- Bom , mas também ele não era casado. Ele vivia saindo aí com um monte de moça, né ? É, porque o padre falou, o padre falou na missa que os casais normais e bem casados estão protegidos por Deus. É... (voltandose para o espectador) mas, e a mancha de batom (ruído de um alarme), e aquelas doenças (ruído)? Como é que eu vou saber o que o Adelson faz fora de casa?

Seqüência 2: (S2)

Lucilene senta-se no sofá e fala:

- Hora da minha novela, a hora sagrada.

Liga a televisão que é um objeto de cena estilizado. Na tela da tv vemos um casal em plano médio representado pelos mesmos atores e que tem os mesmos nomes, porém estão vestidos de uma outra forma, mais chique. 0 diálogo na novela tem início:

- Adelson, vamos acabar com essa palhaçada, eu já descobri tudo!

- Tudo?

- Sim, tudo, tudinho!

Câmera enquadra Lucilene em close assistindo atentamente a novela

- Tudo, tudinho mesmo?

- É.

- Há, não seja tolinha, eu não tenho nada prá esconde, a minha vida é um livro aberto! Você já contou prá alguém? 
- Não, mas vou contar, vou contar.

- Meu Deus, é o fim! Mas, afinal Lucilene, o que foi que você descobriu?

- Descobri que você tem outra, que nossa filha não é mais virgem, que o namorado dela vai ser enfermeiro. Quer dizer, esquece essas duas últimas coisas que eu the falei.

- Enfermeiro, aquele frangote! Bem que eu sabia, que sem-vergonha!

- Eu deveria deixá-lo.

- Não, não.

- Sim.

- Não. Eu não sou nada sem você.

- É verdade, é verdade. A partir de hoje você vai dormir no tapete da sala.

- Não, isso não, pelo amor de Deus, Lucilene! Eu não consigo dormir sem você, sem o seu aconchego, eu tenho medo. Além do mais, a gente não tem tapete na sala.

- Tá bom, bobinho, eu não vou fazer isso, mas a partir de hoje você vai ter de usar a camisinha (tira uma camisinha da bolsa).

- Aí também não, né, Lucilene, peraí, sem chance, né, sem chance!

Lucilene que está fora da novela é vista em câmera baixa e fala:

- Ô Adelson, você tinha que estragar a minha novela, que coisa! Ai, será que eles ficam junto no final? Será que ela conta tudo prá ele? Ah, eu acho que sim, porque novela é sempre assim, tudo dá certo, tudo acaba bem.E na vida real (corte para Lucilene vista em ângulo normal) como as coisas acontecem?

Escuta-se a voz de Adelson:

- Ô de casa, cheguei!

Ela se levanta, as luzes do cenário se acendem.

- Hoje a gente tem aquela conversa. É camisinha ou chão da sala, e sem tapete!

Ela sai de cena, sobe o som da música e os créditos, com imagens de coração feitas em computação gráfica. 
Ao variar os pontos de vista sobre o problema das $\mathrm{DST}_{\mathrm{s}}$, ao abordar os pontos de vista da mulher, dos adolescentes, do marido, do dono do bar que o marido freqüenta, esse vídeo colabora para que as emoções despertadas possam ser melhor elaboradas. A variedade de opiniões fornece um panorama da diversidade e riqueza de pontos de vista sobre o modo de viver, contribuindo para a enriquecer a percepção do espectador sobre as questões apresentadas. A ressalva que gostaria de fazer é que embora os pontos de vista sejam variados, o ponto de vista deste vídeo (e também do vídeo Denise) é o olhar da mulher sobre a vida, o modo com que a mulher, partir de uma posição na sociedade, encara a vida. $O$ público-alvo prioritário deste vídeo é a mulher. Vemos que existe uma visão feminina do comportamento do homem, sendo apontado e caricaturizado o comportamento machista (S1).

Por ser um vídeo de ficção gravado totalmente em estúdio - com exceção das entrevistas de rua - o cenário construído cria um ambiente doméstico no qual se desenvolve a maior parte da trama. O cenário é estilizado e utilizam-se elementos significativos para compor este ambiente, como utensílios de cozinha e panos de prato pendurados num varal. Numa das seqüências aparecem em primeiro plano mantendo-se a personagem num plano mais afastado (Figura 21). Em outra seqüência, vemos a protagonista recolhendo a roupa do varal, com a câmera desenvolvendo um movimento de acompanhamento da cena (travelling). Este movimento gera um ritmo e colabora para criar um clima que visa representar o contexto da vida doméstica e privada.

O corpo da protagonista se movimenta apenas no ambiente doméstico. Seus gestos executam as atividades de dona de casa: varrer, lavar, preparar a comida, etc. Quem se movimenta no ambiente externo ao lar é o marido. Os entrevistados também se encontram em ambientes externos, na rua. Como foi citado acima, trazem a visão da sociedade sobre o assunto. 


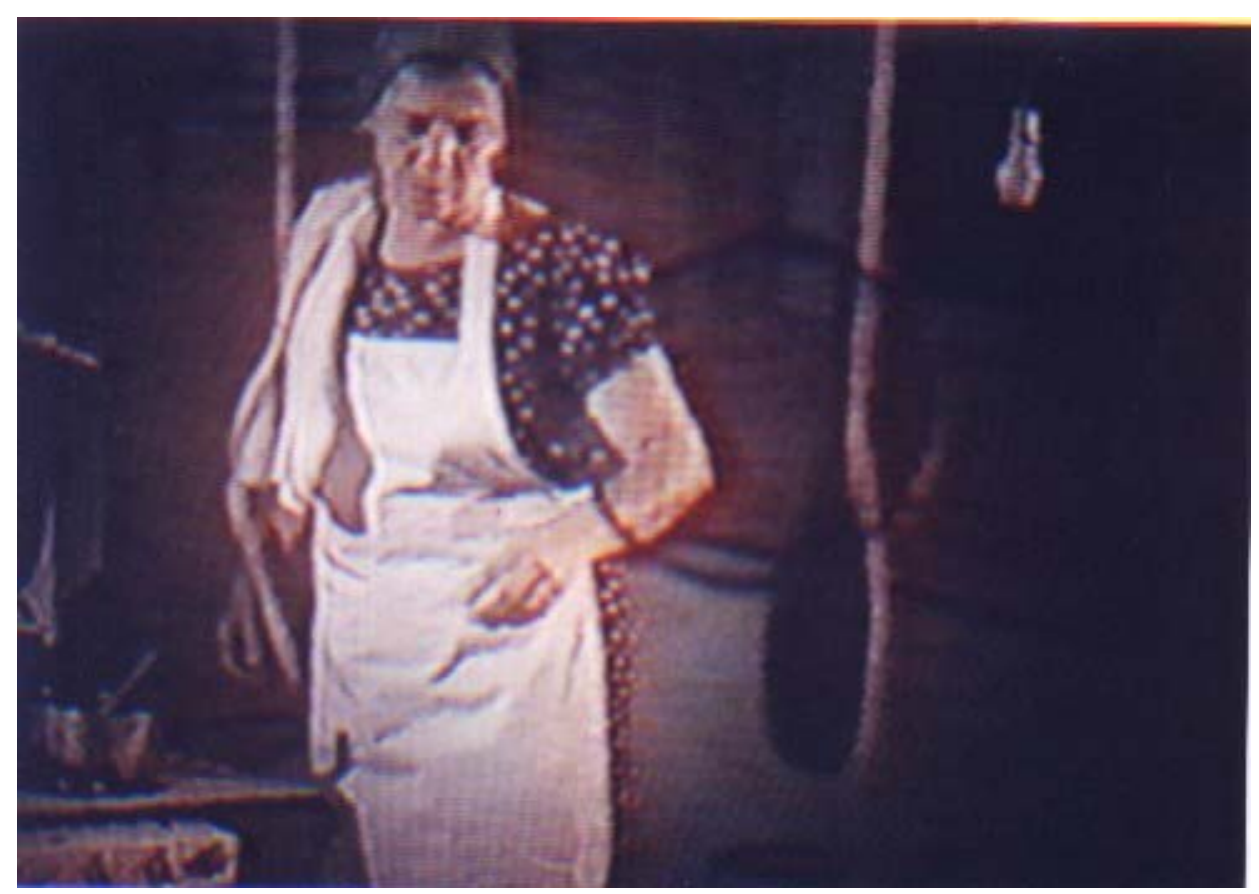

Figura 21

Os adolescentes presentes na trama são os responsáveis por trazer novas informações, de uma forma mais positiva. Os filhos do casal tocam nos temas da sexualidade e da prevenção. Numa das cenas com a filha , em que a mãe fica sabendo que ela não é mais virgem e usa camisinha, as imagens são editadas com efeitos e sons de ruídos (rajadas de metralhadoras) acelerando o ritmo e aludindo à agitação que caracteriza os adolescentes. A cena em que o filho aparece é muito breve, ele entra, pega uma camisinha, comenta sobre isso, e sai.

$\mathrm{Na}$ seqüência em que vemos o marido trabalhando como ascensorista, aparecendo no elevador à direita do quadro, o lado oposto da tela fica vazio. O recurso na construção do quadro é criativo, no sentido que o enquadramento realizado visa criar um descentramento proposital. Ao se esvaziar o centro cria-se uma situação de tensão visual (Arnheim, citado por AUMONT,1993,p.158), que no caso desta cena nos faz imaginar os interlocutores e preencher de certa forma o vazio. Durante a cena, em alguns momentos, o personagem se dirige a outros supostos personagens, mas nós não os vemos. O enquadramento do personagem masculino num 
dos cantos da tela pode ser entendido como uma forma de isolar as concepções que ele tem do mundo, minimizá-las e diminuir sua importância.

A perspectiva diferente em que são apresentadas as imagens das pessoas entrevistadas na rua, de forma oblíqua à base do quadro (Figura 22), é um recurso criativo que, ao provocar propositalmente um descentramento e um ângulo diferente de visão, colabora para marcar de uma forma diferenciada as abordagens de pessoas fora do contexto familiar. Estas visões contribuem para configurar a concepção social do corpo. Os entrevistados colocam ser legítimo a esposa (protagonista) exigir o uso da camisinha e que o marido deve ter esta atenção com a esposa, pois ela é a mãe dos filhos dele. Outros levantam questões que colocam em pauta a desconfiança: se há uma mancha de batom na camisa é porque existe algo mais; se a esposa exigir o uso do preservativo o marido vai achar estranho. Nestas falas percebemos que os entrevistados referem-se à desconfiança presente nas relações, assim como a perspectiva de se garantir face a ela. Abre-se a possibilidade de discutir a questão de que é necessário se proteger com o uso da camisinha, mesmo que a pessoa tenha uma relação estável, pois o perigo de contaminação existe independente deste fato.

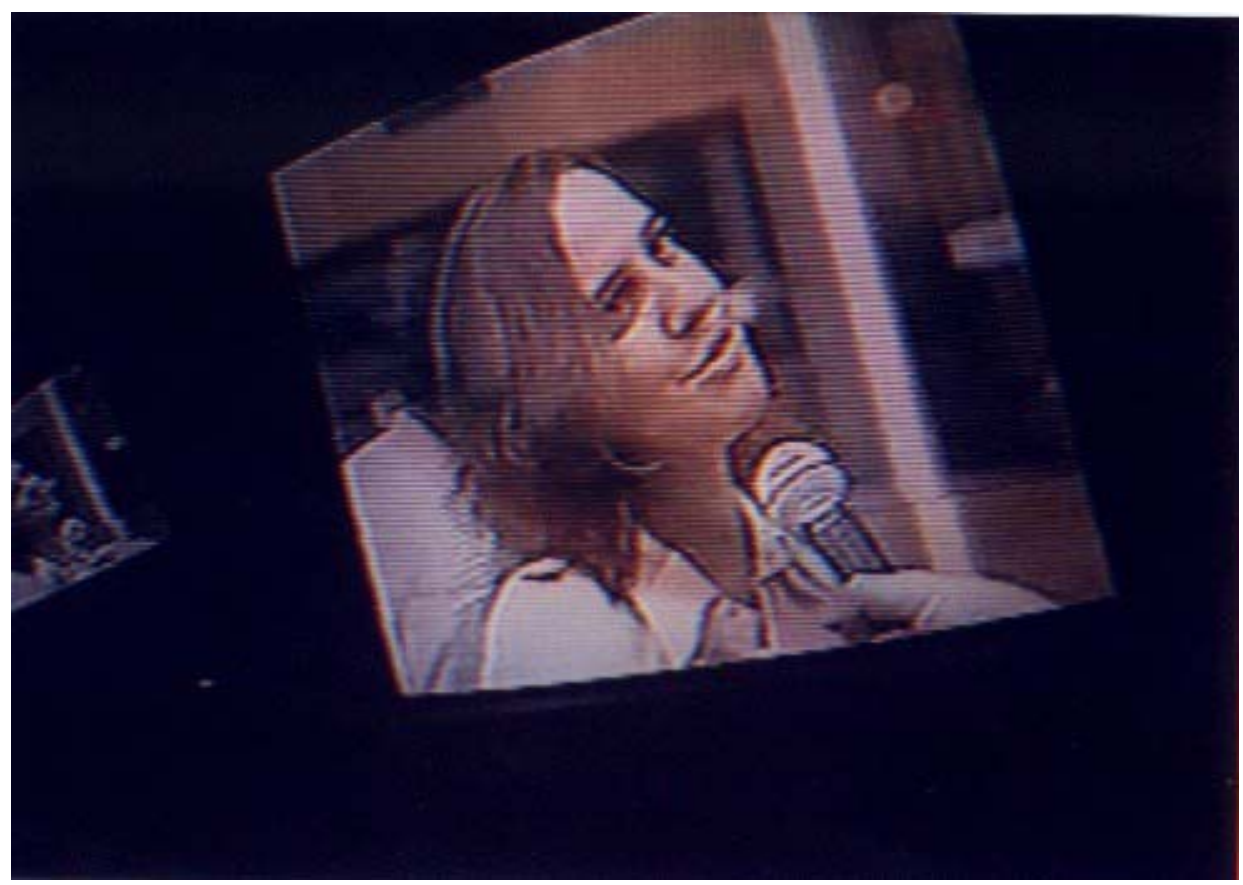

Figura 22 
O vídeo apresenta uma grande vantagem em comparação com os demais, a participação de uma conhecida atriz que representa a protagonista e conduz a trama (Rosi Campos, que atua no programa infantil "Castelo rátim-bum"). O custo da produção de um vídeo aumenta com a contratação de atores profissionais, mas garante um ganho significativo em termos expressivos, ou seja, na interpretação das várias nuances de emoções e reações.

A narrativa do vídeo desde o início vai configurando o corpo da personagem de forma a retratar a submissão seja aos padrões sociais, seja ao marido, no âmbito privado. A partir de um certo momento, mais no final, a situação começa a se inverter. Começa a se estabelecer um esboço desta inversão, a partir do momento em que a protagonista se pergunta porque não faz nada pra mudar a situação de submissão. Ela diz: "Porque a gente tem sempre que abaixar a cabeça?". Ela afirma então que tem os seus direitos. Neste momento sua imagem é enquadrada em outro ângulo, em câmera baixa, dando uma idéia de superioridade, de poder. (Figura 23)

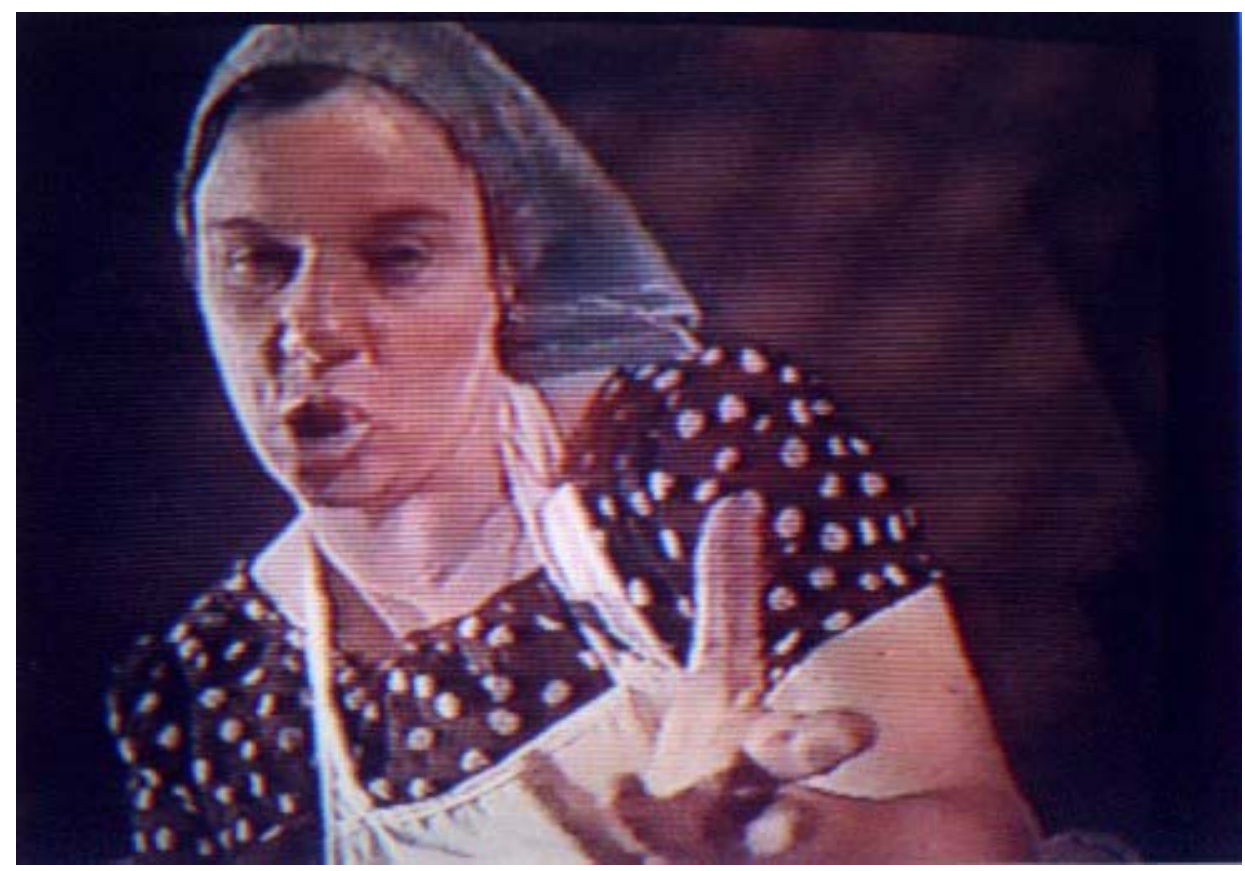

Figura 23

Ela passa de submissa a "poderosa". O que é dito, de não abaixar a cabeça, é mostrado. Mantendo-se o eixo vertical, seu corpo como um todo 
aparece elevado, em função do ângulo de gravação. É como se o espectador estivesse olhando-a de baixo para cima; desta forma seu corpo adquire um peso e uma importância maior. A idéia de ter a cabeça baixa configura a submissão ao que os outros determinam, é o fato de não ter vontade, nem decisão próprias. O levantar a cabeça é se contrapor a esta situação.

Analisando um pouco o que a cabeça simboliza podemos ver como que seu significado foi historicamente configurado. Para os romanos e para muitos povos a cabeça era o órgão que continha a alma. (LE GOFF, 1989). Este autor aponta, citando Paul-Henri Stahl, que a prática da decapitação nas sociedades antigas e medievais era motivada pelo desejo de destruir e se apropriar do poder de alguém, através da posse da sua cabeça ou de seu crânio. Existem muitas referências relativas às partes do corpo como metáforas da vida política, como na Idade Média em que o governante é considerado a cabeça do poder. No cristianismo Cristo é considerado a cabeça da Igreja e Deus a cabeça de Cristo, configurando um sistema hierarquizado. (LE GOFF, 1989,p.14/17). No mundo contemporâneo, com a dicotomia corpo/mente, vemos também que se configura uma hierarquia, com a mente e a razão, representada pela cabeça, dominando e dirigindo o corpo, as emoções. Na linguagem do senso comum, ao referir-se a uma família ou a um casal, fala-se muitas vezes que o marido é o cabeça , é ele quem manda.

Desta forma ao se questionar porque deve abaixar a cabeça, a personagem inicia uma reflexão sobre o corpo político, sobre o poder a que ela está submetida. A partir daí é que se dá uma virada na trama narrativa e que ela se transforma deixando de ser tão submissa.

Apesar deste movimento que a personagem faz, a resistência passa pela afirmação dela como indivíduo. Por ser uma ficção cuja narrativa é encenada no espaço privado, a resistência passa pela afirmação individual, a participação coletiva não se coloca. A escolha de um formato, de uma opção estética, de um argumento, faz com que sejam delimitadas as opções. Provavelmente neste vídeo não haveria espaço para uma opção 
pela resistência através do coletivo, pois o centro da história gira em torno de alguns indivíduos - marcadamente em torno da dona de casa - apenas no espaço privado (somente o homem , o marido,é mostrado circulando no espaço público). Nos outros materiais a resistência é colocada de outra forma.

A referência existente no vídeo aos meios de comunicação - o rádio e a televisão como objetos de cena - fornece elementos para uma reflexão a respeito da função metalingüística. $O$ vídeo é um produto comunicativo que utiliza uma linguagem muito próxima à da linguagem da televisão. Ao inserir imagens de uma novela de televisão, temos uma reflexão da linguagem dentro dela mesma. Nos momentos em que aparecem na trama, tanto a tv quanto o rádio, revelam a importância dos códigos de comunicação destes meios na vida da protagonista, e podemos dizer, na vida das pessoas em geral. O rádio é como se fôsse o confidente e o conselheiro da dona de casa. Com recursos de computação gráfica cria-se a possibilidade dele falar através de uma boca (Figura 24) de onde saem pequenas figuras em forma de coração.

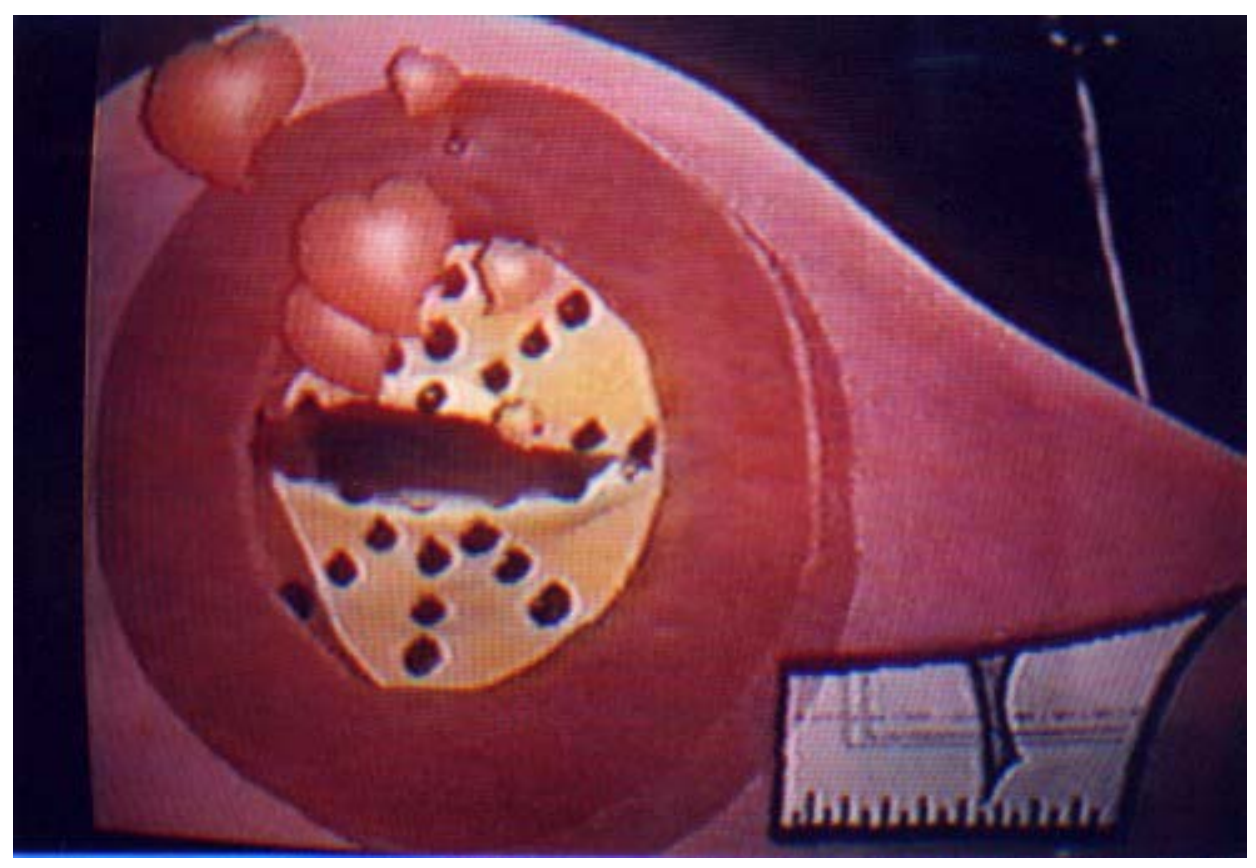

Figura 24 
A voz do locutor com suas falas românticas interferem na vida da personagem, auxiliam-na a refletir, enfim, ele é a sua companhia. A função da novela é semelhante, provavelmente seja mais marcante devido ao fato de que a televisão utiliza-se de uma linguagem que não é somente sonora, mas também visual. Na novela (S2) a protagonista se vê do lado de lá da tela (Figura 25), da mesma forma em que os espectadores se projetam nos programas de televisão, de vídeo e no cinema. Esta projeção faz com que a protagonista possa refletir e se transformar. $\mathrm{O}$ recurso do vídeo é pensado também desta forma, como um instrumento que auxilie as pessoas a refletir, através da projeção e identificação.

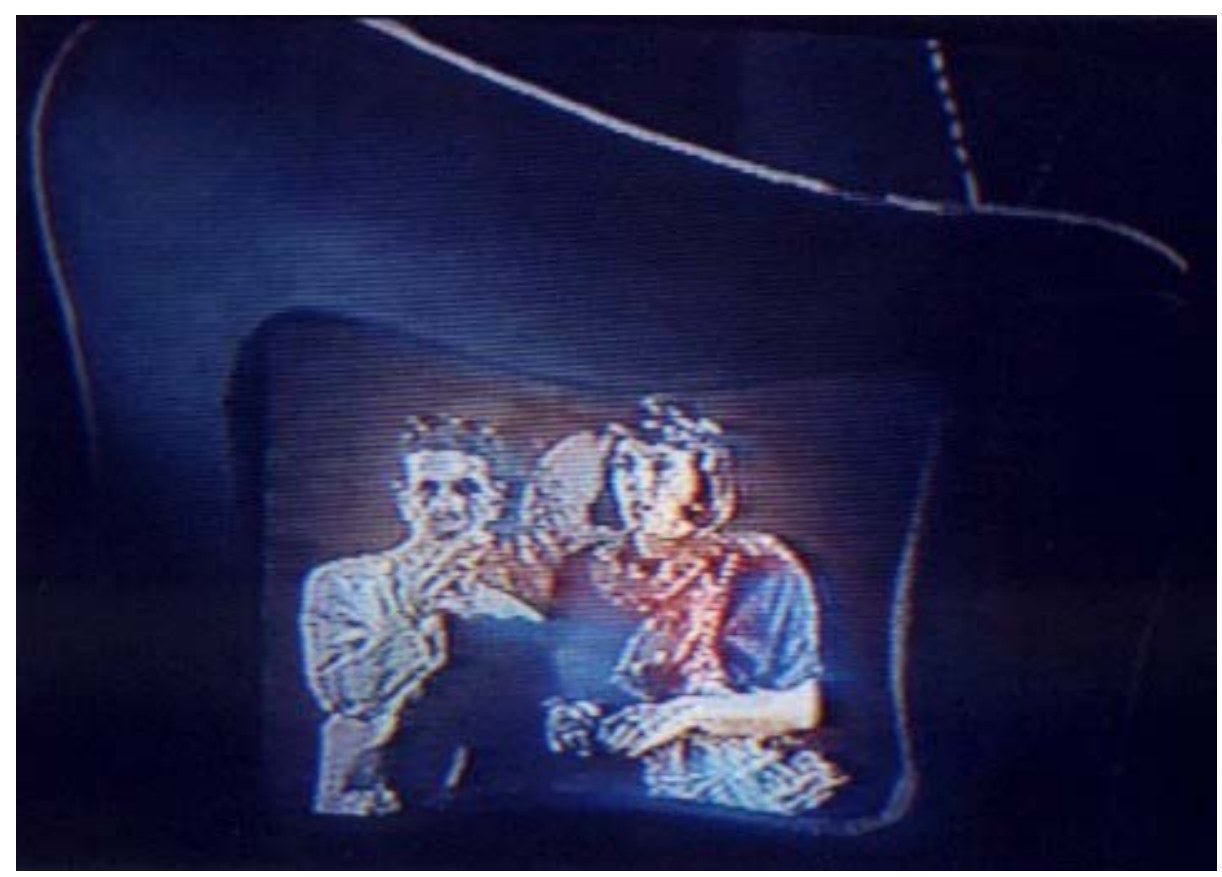

Figura 25

$\mathrm{Na}$ S2 vemos que a possibilidade de uma mudança de situação se configura. Na novela é ela que representa o poder. Ela se vê na novela falando sobre questões que vai buscar conversar na vida real. Na realidade o diretor brinca um pouco com esta questão, caricaturando a situação, com uma linguagem bem humorada. $O$ fato de se ver na novela possibilita uma identificação para a personagem. Sabemos que um dos grandes motivos do sucesso das novelas deve-se a esta razão, a esta possibilidade de se ver na tela. Na cena de novela as coisas dão certo, o casal busca se comunicar e 
resolver seus problemas, o que leva a personagem refletir sobre a possibilidade de fazer a mesma coisa na vida real.

Numa certa seqüência a protagonista aproxima-se da câmera e dirige-se ao espectador, como se estivesse confidenciando a ele algo que ela está pensando. (Figura 26)

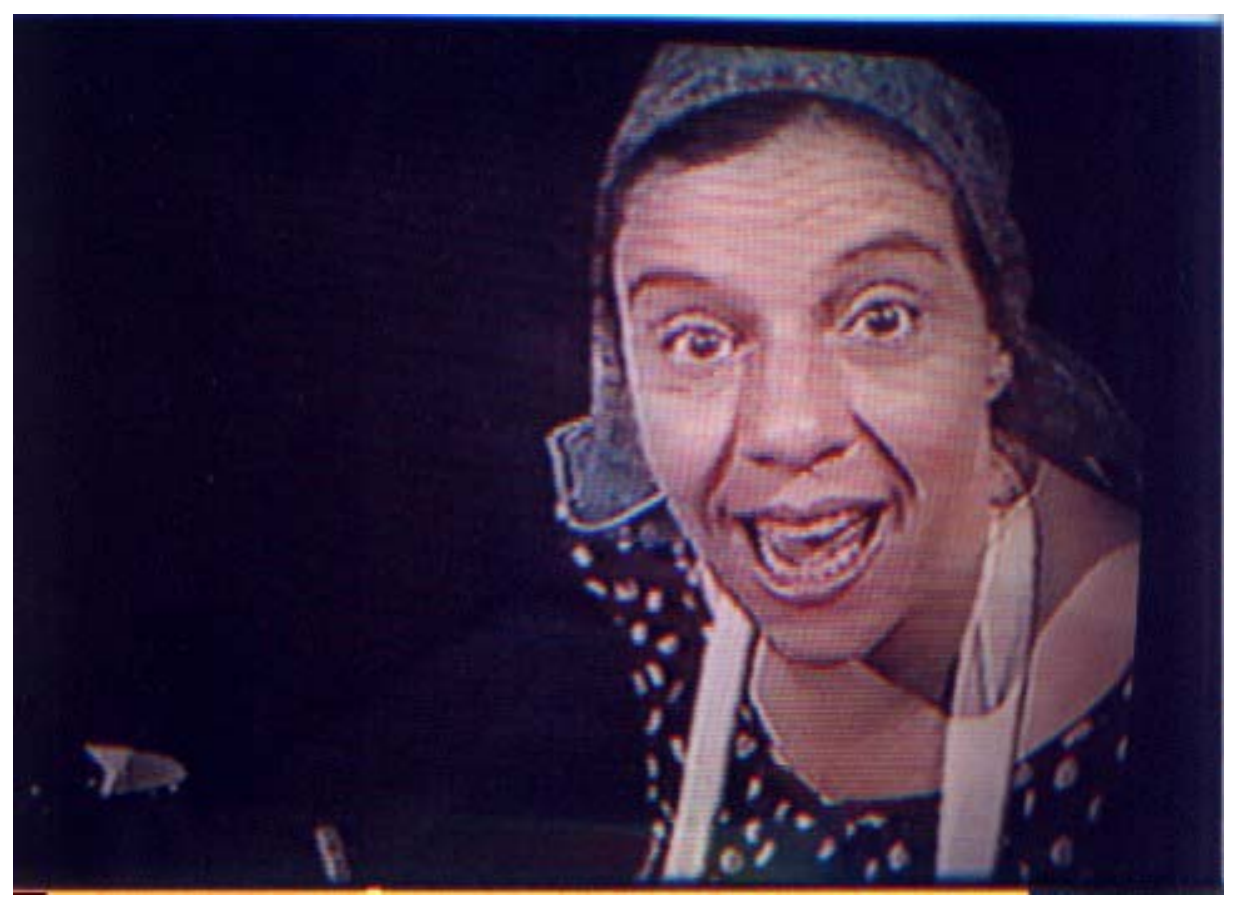

Figura 26

Em outros momentos, mesmo sem fazer o movimento de aproximação, ela também se dirige ao espectador, fazendo observações ou refletindo sobre algo olhando para a câmera. Isto faz com que suas reflexões sejam dirigidas a quem está assistindo, para que as perguntas que ela faz sejam também perguntas que o espectador busque responder. 


\section{Vídeo 6: Quem vê a cara vê AIDS.}

Sinopse: Em Recife um repórter colhe depoimentos dos moradores sobre AIDS e orienta sobre cuidados e prevenção.

\section{Seqüência 1: (S1)}

O repórter, chamado Brivaldo, entrevista pessoas que são moradoras de um bairro popular do Recife. Ele se aproxima de um jovem para mais uma entrevista.

- O pessoal dali tava dizendo que você tá com Aids, é verdade, não?

O rapaz brincando:

- É. Não tavam dizendo?

— E é? Você tá mesmo? Não sabe ...

- Não, eu acho que não.

O repórter faz gestos, mostrando o rapaz:

- Não, né, tá com a cara saudável, bonita, elegante, simpático ...

O rapaz faz pose se mostrando forte, levantando os ombros. A garotada em volta faz uma gritaria. Brivaldo continua:

- Se tiver uma gata no Pina (provavelmente é o nome do bairro) que gostar de você, pode vir que você está completamente saudável...

- Saudável!

Rindo, ele faz novamente pose de forte e bate no peito. (Figura 27)

Sobe o som da música cantada por Ney Matogrosso, enquanto um plano mais geral mostra adolescentes se divertindo com a cena: "Telma eu não sou gay, o que falam de mim são calúnias (....) ; não me maltrate assim, não posso mais viver..."

Baixa o som e Brivaldo, caminhando, passa para outra entrevista no mesmo local. 


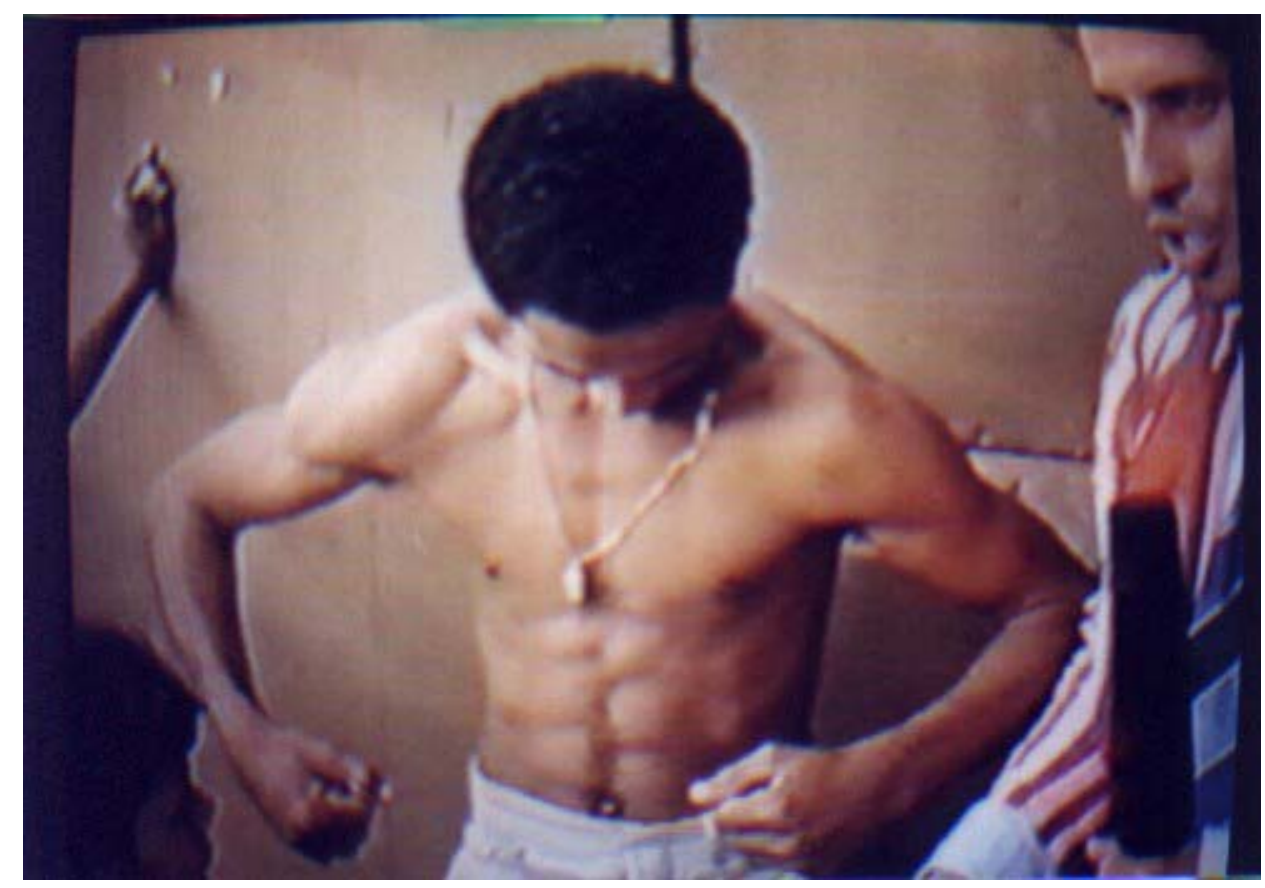

Figura 27

Seqüência 2: (S2)

O repórter anda pelas ruas do centro da cidade e pergunta para policiais que passam montados em cavalos:

- Que é que a polícia militar de Pernambuco está fazendo com relação a Aids, tá sabendo, não?

- Não. (murmúrio)

Ele se volta para outro e nenhuma resposta. Pergunta novamente a outro policial:

- O amigo normalmente usa camisinha?

- Nada disso.

O repórter se volta para a câmera falando para o espectador:

- A polícia militar de Pernambuco não usa camisinha de vênus !!!

Seqüência 3: (S3)

No mesmo espaço físico sem cortes Brivaldo se volta para outro pedestre.

Vemos então os dois em primeiro plano:

— Você sabe que você entrou no ar na Vila Tururu ? Que é que tem feito para se prevenir da Aids, meu amigo?

Ele põe o braço no ombro do entrevistado e este responde: 
- Eu acho que a melhor coisa a se fazer é se prevenir, né?

- Como é que você tem feito?

- Camisinha, né? Tem que botar camisinha porque é melhor prevenir que remediar.

- Contagia só pelo sexo, pelo sangue, ou tem outras formas de contaminação?

- Eu acho que até agora, os estudos foram feitos, a maneira muito mais fácil de se pegar é pelo contato sexual e a contaminação sanguínea.

- Por exemplo, você não teria preocupação nenhuma se eu te dissesse que eu era um aidético e tava aqui perto de você?

- Não, porque aí não vinha contaminação de jeito nenhum.

Aos poucos, sutilmente, Brivaldo vai se aproximando fisicamente cada vez mais:

— Você não tem medo, por exemplo, da minha saliva?

- Não porque a gente não vai trocar beijo, de jeito nenhum.

- A minha saliva pode tar caindo na sua boca ...

Ele se aproxima mais e o entrevistado, rindo, faz um movimento de afastamento com o corpo. (Figura 28)

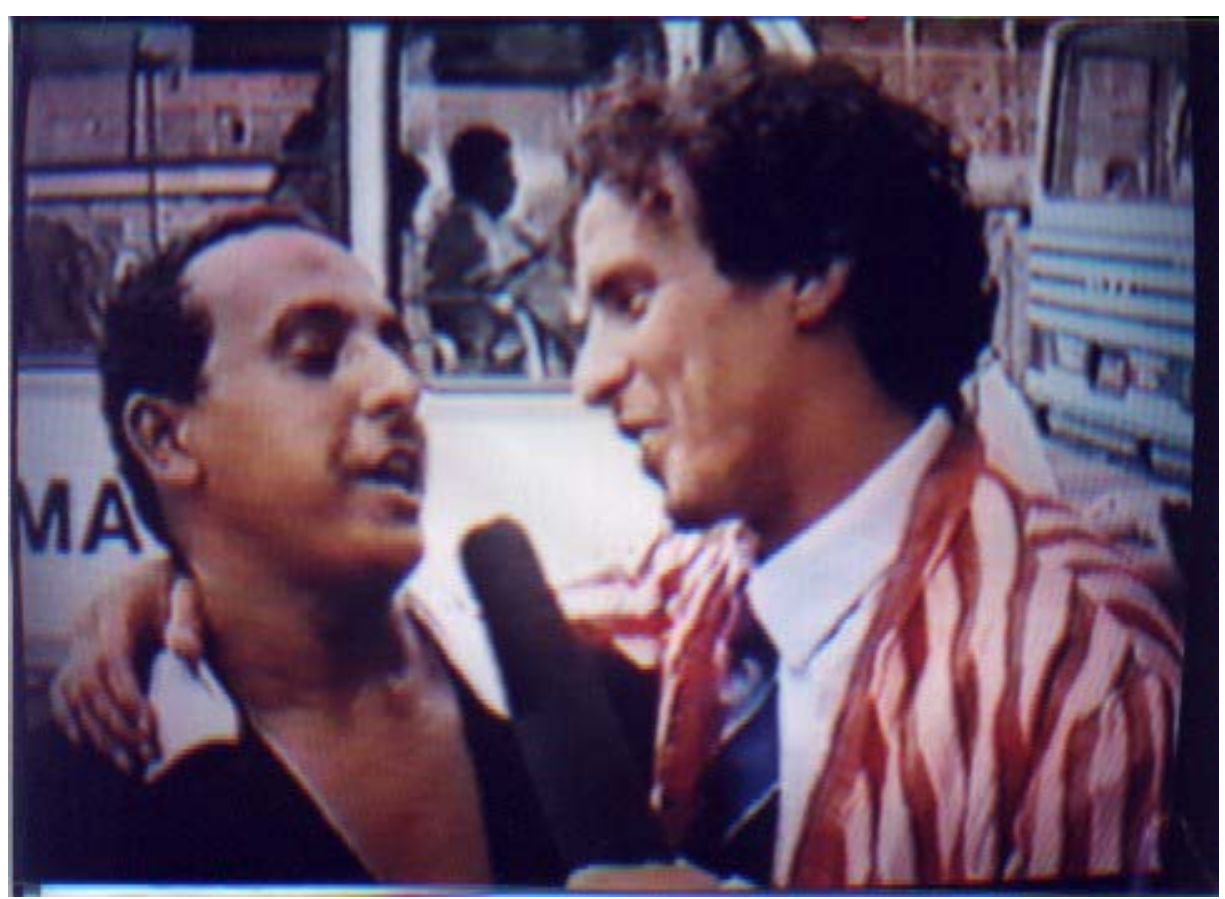

Figura 28 
A partir da idéia da campanha sobre Aids do Ministério da Saúde "Quem vê cara não vê Aids", o vídeo busca refletir e polemizar sobre os preconceitos que vinculam a doença a algumas características visíveis nas pessoas. Utiliza-se do humor para lidar com questões de preconceito, uso da camisinha, sexualidade.

A linguagem corporal do repórter é utilizada para forçar as pessoas a um envolvimento mais emocional com a questão. Ao se aproximar fisicamente dos entrevistados - numa distância considerada além do limite "normal" para um repórter - , sugere-se que ele possa ou estar com a doença ou ser um homossexual Isso acaba por fazer com que o entrevistado sinta-se um pouco incomodado e reaja mais espontaneamente, revelando seu posicionamento carregado de conteúdos ainda não racionalizados. A doença deixa de ser vista como algo abstrato para ser vista como incorporada num indivíduo.

Esse recurso é utilizado para representar e forçar a identificação das características, visuais ou faladas, com a doença visando caracterizar a resistência e o medo. Questiona-se, polemizando em forma de brincadeira, sobre a idéia, errônea, porém comum, de que quem aparenta ser forte e tem uma aparência saudável não tem a doença. $A$ aproximação física do repórter mexe com os medos não expressados. À medida que a proximidade aumenta os receios são expressados. Em nossa sociedade a aproximação física é mais facilmente aceita quanto maior o conhecimento e nível de intimidade entre os interlocutores. Quando isto não existe é presumido que uma certa distância física deva ser mantida.

Vemos que a interferência do social vai até os pormenores das atitudes corporais dos indivíduos. A atitude proposital do repórter de se aproximar de quem ele não conhece surpreende e propicia reações de afastamento corporal. Estas reações espontâneas podem servir, a partir da exibição do vídeo, como pretexto para estimular discussões sobre estereótipos e preconceitos.

Uma das músicas utilizadas "Telma eu não sou gay" (com Ney Matogrosso) na S1 aponta para a analogia presente no senso comum que 
associa a doença com quem é gay, e que em oposição dissocia a doença de quem se mostra machão e forte.

A produção provavelmente deve ter sido barata, é um material com poucos recursos de edição, os cortes são secos, não são utilizados efeitos. As cenas são externas, todas nas ruas, nas portas das casas, dos bares, não há um cenário produzido.O único ator é o que interpreta o repórter.

Neste vídeo busca-se dar voz aos entrevistados, a população; o forte é a intervenção, como no teatro de rua. Ao utilizar-se do personagem do repórter, que é ao mesmo tempo um palhaço, com uma vestimenta extravagante, diferente dos repórteres de televisão, colabora-se para quebrar a resistência das pessoas entrevistadas. A roupa usada pelo repórter assemelha-se a de um palhaço, é um paletó com grandes listras verticais vermelhas e brancas, e a gravata com listras em diagonal, em tons de azul.

O repórter em alguns momentos volta-se para o espectador, buscando uma interação, mesmo que rápida, com quem assiste ao vídeo (função fática). Hoje é um recurso conhecido e de certa forma comum , uma fórmula que a televisão utiliza ao buscar atrair e manter a atenção do público; na época - década de 80 - era uma atitude de certa maneira inovadora.

Não há inserção de detalhes em planos próximos, não se enquadram detalhes do corpo. O corpo aparece na maior parte das cenas ou enquadrado por inteiro, em planos mais gerais que às vezes incluem várias pessoas, ou em plano médio, da cintura para cima em que cabeça, tronco e mãos são focalizadas. O enquadramento das partes altas do corpo faz com que os indivíduos possam ser identificados, é através delas que temos a configuração dos corpos individuais, ou seja, permite a individualização dos corpos, a identificação do "eu". É preciso lembrar que em nossa cultura existe uma dignificação das partes elevadas do corpo, sua face é o signo do indivíduo moderno. RODRIGUES (1999), ao analisar a história do corpo, nos diz que isso nem sempre foi assim. Na Idade Média, por exemplo, as partes baixas, viscerais, eram uma referência constante. A partir do lluminismo, 
com o culto à razão, as partes do corpo elevadas passaram a ser valorizadas.. Segundo o autor a ênfase que hoje emprestamos a face intensificou-se após a emergência do moderno individualismo (p.86).

Em uma das cenas, no início do vídeo em que ele sobe numa escada para se aproximar do outdoor do Ministério da Saúde, vemos o enquadramento de um detalhe do corpo, que é o recorte da boca da moça que é a modelo do cartaz (Figura 29). Este recorte só se torna possível após a exibição de um plano mais geral, em que a foto do cartaz inteiro aparece. As intervenções, porém, que vemos o repórter fazer no seguimento do vídeo não são do mesmo tom do cartaz, mas o seu oposto, como bem diz o título do vídeo. As perguntas que se seguem provavelmente não são as que sairiam da boca da modelo). O enquadramento da boca também pode significar a necessidade de se falar mais sobre a doença e formas de prevenção, de se dar voz a população para que ela expresse o que entende sobre a doença, assim como seus comportamentos face a esta realidade.

A estratégia da campanha estatal é a utilização o medo como recurso de convencimento da população visando a prevenção. O perigo da doença, tanto para o corpo individual quanto o social, configura um corpo político que, para ser mantido "saudável", necessita ser controlado. A opção, na época, era a utilização do medo como recurso para a realização deste controle. 


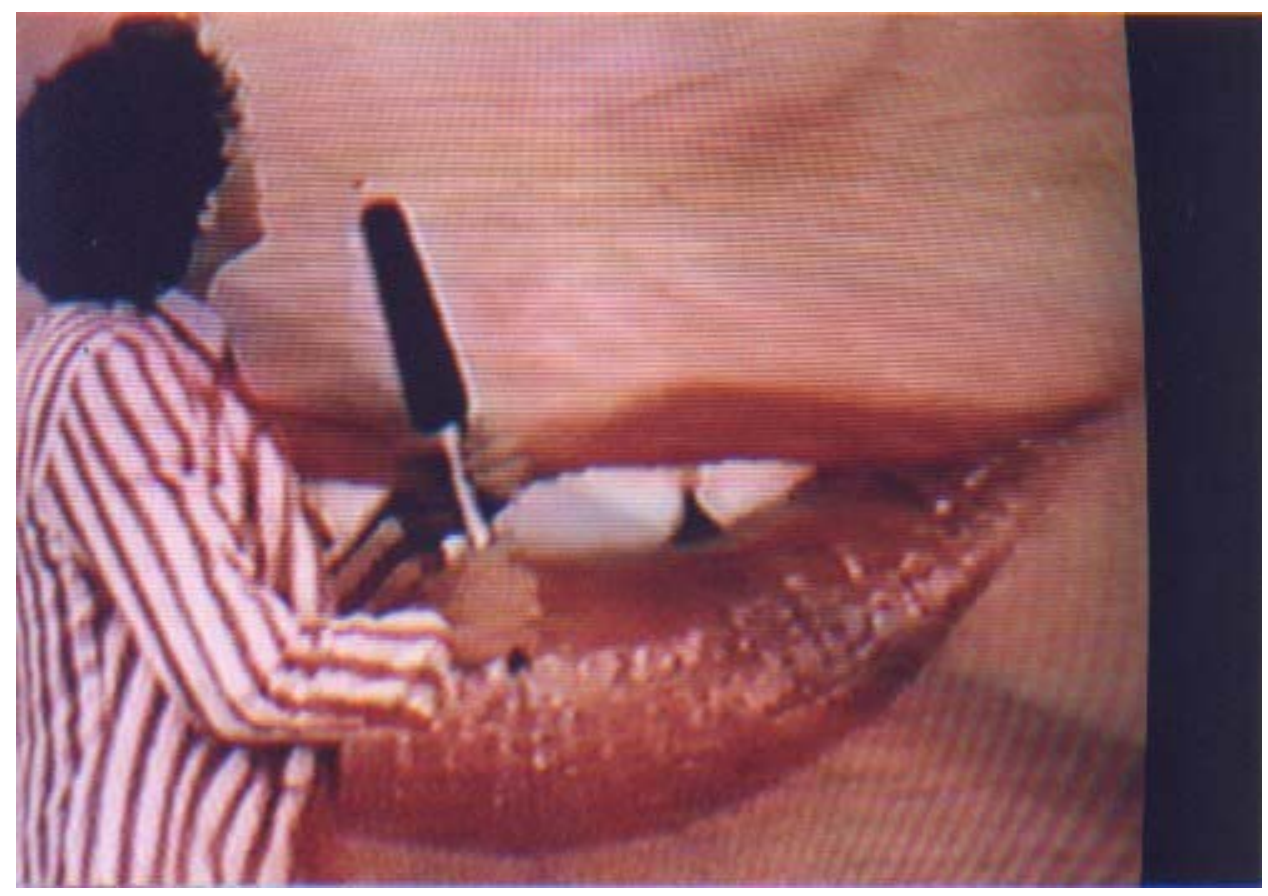

Figura 29

Como o problema da aids supõe que haja referência também às partes baixas do corpo, o vídeo utiliza um recurso que transfere o enquadramento destas partes para outra parte do corpo ou para objetos que possam substituí-las. Em uma das cenas o repórter coloca a camisinha em seu dedo, fazendo com que este simule o pênis (Figura 30). Em outro momento ele pede a um entrevistado que coloque a camisinha no microfone (Figura 31). Por uma certa semelhança de forma essa transferência é possível, sendo utilizado um recurso de linguagem em que a exibição do órgão sexual masculino é então substituído por outra parte do corpo e por um objeto. Apesar de não haver uma exibição direta das "partes baixas" a referência a elas é bem marcada e gera reações por parte dos entrevistados, principalmente porque o repórter utiliza o humor para lidar com as situações criadas. Estas reações são compreensíveis em função do receio que há em nossa cultura em lidar com estas partes do corpo. Somente enquanto mercadorias é que elas são valorizadas. As partes baixas do corpo enquanto sede da sexualidade são "vendidas " na publicidade, nas revistas, nas propagandas de lingerie da televisão, nos filmes pornôs. Desta forma, apesar da reação de algumas camadas da sociedade, elas são socialmente aceitas. De outra forma há um certo receio por parte das pessoas em lidar 
com a questão, apesar das várias transformações pelas quais vem passando a sociedade. Inclusive a aids, que tem no ato sexual uma das formas de transmissão, pode ter um papel na desmistificação e na quebra de alguns tabus com relação aos órgão sexuais e a sexualidade como um todo. A partir de discussões sobre a doença, e sobre a saúde, pode-se buscar uma compreensão do corpo como uma totalidade, em que as partes podem ser integradas num todo, que é o corpo do indivíduo dentro de um contexto cultural, social e político, no qual sensações, emoções e razão estão interligadas.

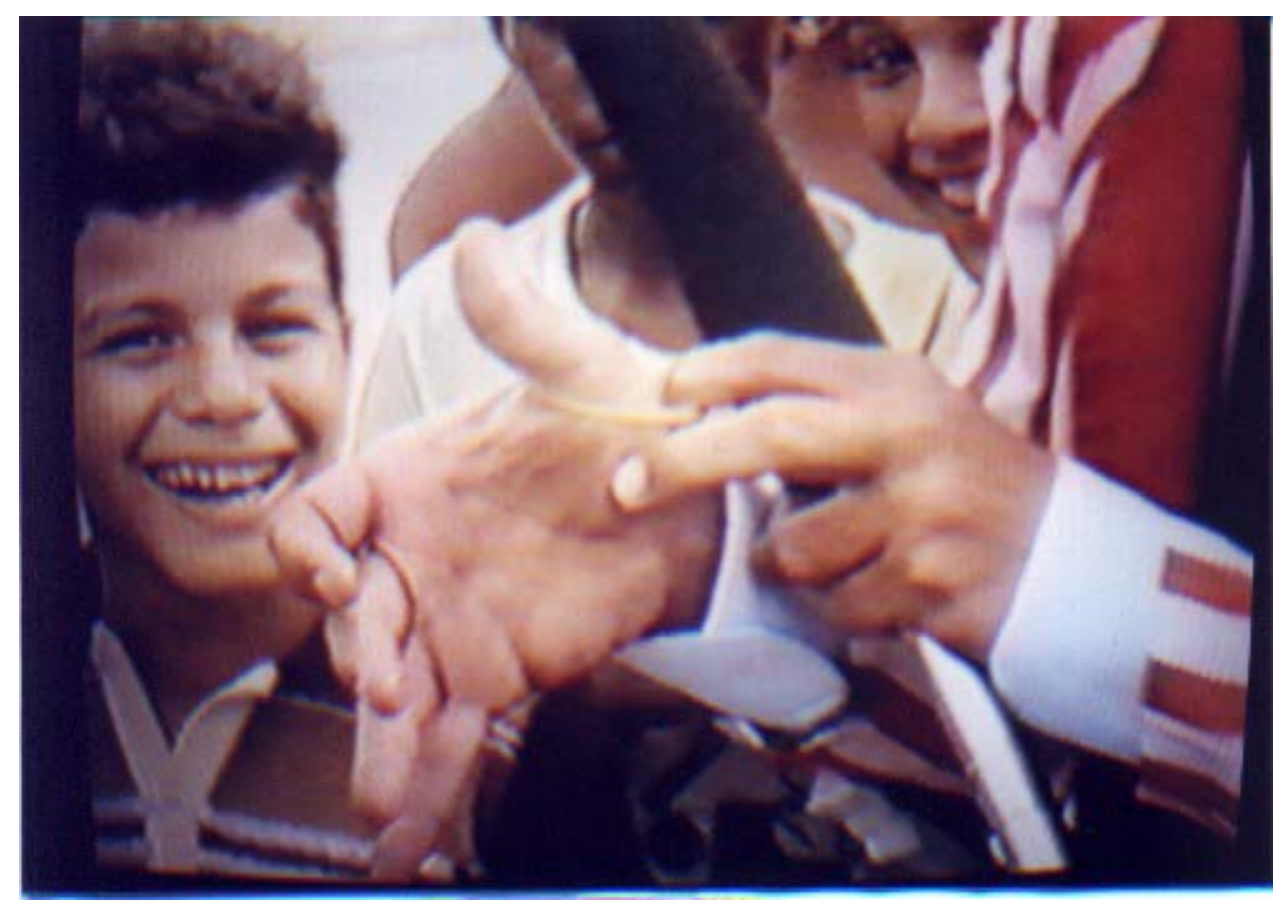

Figura 30 


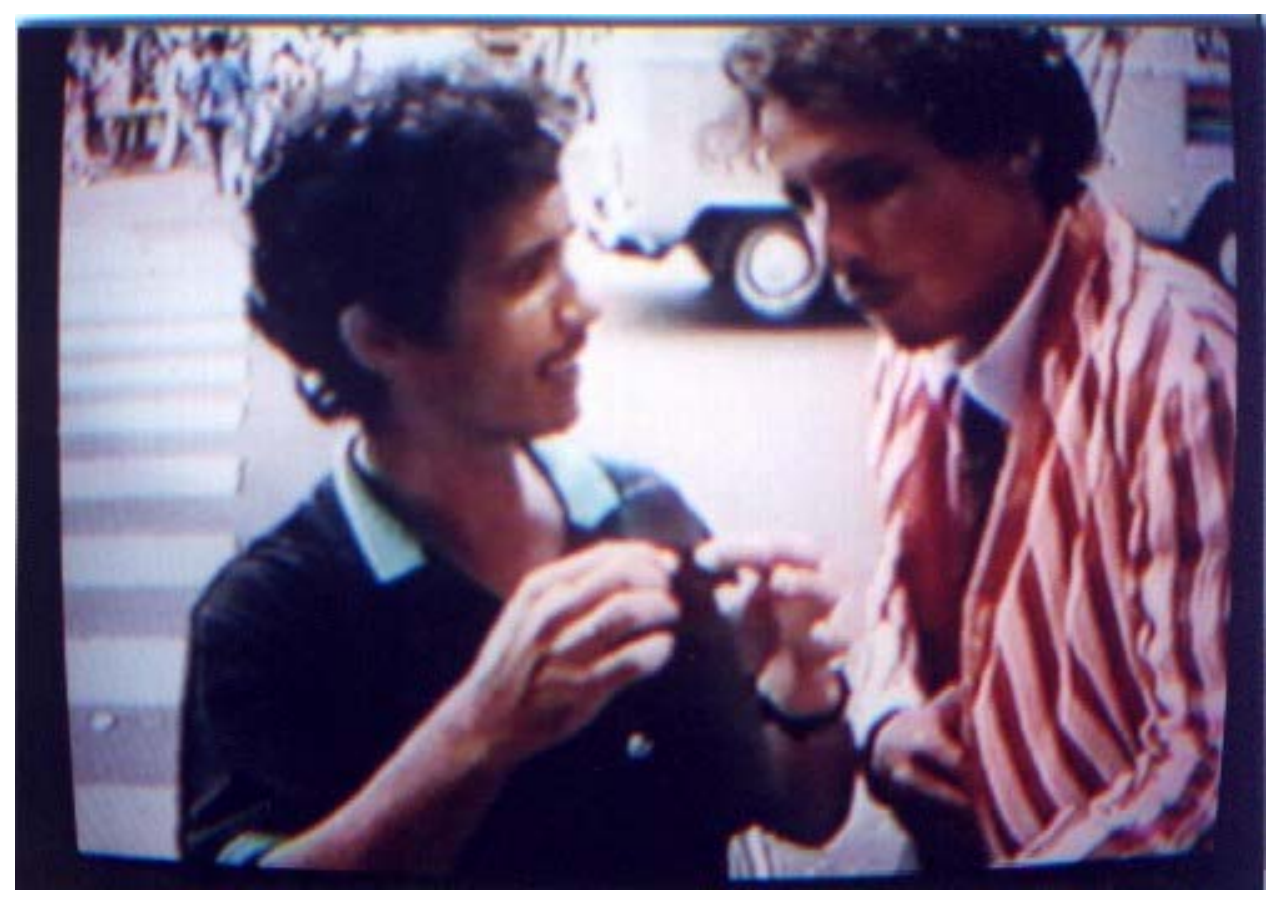

Figura 31 


\section{Quadros descritivos}

Para melhor compreensão da interpretação teórica dos seis vídeos em estudo, elaborou-se, como complementação do texto acima apresentado, quadros que descrevem a forma de representação das oposições segundo as três dimensões do corpo. Ressaltamos que nos diferentes materiais cada dimensão é mais ou menos enfatizada, tendo um peso maior ou menor na configuração do significado do corpo como um todo.

\begin{tabular}{|c|c|c|c|c|c|}
\hline \multicolumn{6}{|c|}{ CORPO INDIVIDUAL / EXISTENCIAL } \\
\hline \multicolumn{6}{|c|}{ VÍDEOS } \\
\hline Divina Previdência & $\begin{array}{l}\text { Atendimento } \\
\text { Médico }\end{array}$ & $\begin{array}{l}\text { Amamentação: } \\
\text { vamos recuperar } \\
\text { esta prática? }\end{array}$ & Denise & Mancha de Batom & $\begin{array}{l}\text { Quem vê a cara vê } \\
\text { AIDS }\end{array}$ \\
\hline $\begin{array}{c}\bullet \text { oposição } \\
\text { indivíduo/ sociedade: } \\
\text { peso das instituições } \\
\text {; "morte" do indivíduo } \\
\text { face ao gigantismo e } \\
\text { impessoalidade das } \\
\text { instituições } \\
\text { - drama pessoal em } \\
\text { oposição à frieza dos } \\
\text { representantes das } \\
\text { instituições }\end{array}$ & $\begin{array}{l}\text { - visível / invisível : } \\
\text { corpo como território } \\
\text { desconhecido } \\
\text { • oposição } \\
\text { indivíduo/ } \\
\text { sociedade : busca do } \\
\text { autoconhecimento do } \\
\text { corpo para se } \\
\text { contrapor ao que é } \\
\text { socialmente instituído }\end{array}$ & $\begin{array}{c}\bullet \text { oposição } \\
\text { natureza/ cultura: } \\
\text { amamentação como } \\
\text { ato natural do corpo } \\
\text { da mulher; questões } \\
\text { sociais dificultando } \\
\text { este ato } \\
\bullet \quad \text { integrar } \\
\text { sensações e } \\
\text { emoções; integrar } \\
\text { dimensões biológicas } \\
\text { e sociais para } \\
\text { vivenciar um corpo } \\
\text { integrado }\end{array}$ & $\begin{array}{c}\bullet \text { oposição } \\
\text { indivíduo/ sociedade: } \\
\text { valorização da } \\
\text { experiência individual } \\
\bullet \quad \text { busca do } \\
\text { autoconhecimento do } \\
\text { corpo para se } \\
\text { contrapor ao que é } \\
\text { socialmente instituído } \\
\bullet \quad \text { busca de } \\
\text { concretização de } \\
\text { sonhos e desejos } \\
\text { para vivenciar um } \\
\text { corpo integrado }\end{array}$ & $\begin{array}{l}\text { - oposição indivíduo } \\
\text { / sociedade: } \\
\text { afirmação de desejos } \\
\text { individuais face aos } \\
\text { condicionamentos } \\
\text { sociais } \\
\text { - busca da } \\
\text { compreensão da } \\
\text { situação enquanto } \\
\text { indivíduo no mundo }\end{array}$ & $\begin{array}{c}\text { • oposição } \\
\text { razão/emoção: } \\
\text { reações dos } \\
\text { entrevistados não são } \\
\text { apenas racionais, } \\
\text { contém medo, } \\
\text { vergonha, } \\
\text { desconfiança } \\
\text { • oposição } \\
\text { proximidade / } \\
\text { afastamento: medo } \\
\text { da doença gera } \\
\text { reações físicas de } \\
\text { afastamento corporal }\end{array}$ \\
\hline
\end{tabular}


CORPO SOCIAL

VÍDEOS

\begin{tabular}{|c|c|c|c|c|c|}
\hline Divina Previdência & $\begin{array}{l}\text { Atendimento } \\
\text { Médico }\end{array}$ & $\begin{array}{l}\text { Amamentação: } \\
\text { vamos recuperar } \\
\text { esta prática? }\end{array}$ & Denise & Mancha de Batom & $\begin{array}{l}\text { Quem vê a cara vê } \\
\text { AIDS }\end{array}$ \\
\hline $\begin{array}{c}\text { • oposição } \\
\text { indivíduo/ sociedade: } \\
\text { corpo dos "excluídos" } \\
\text { sem valor para a } \\
\text { sociedade } \\
\text { - puro / impuro : } \\
\text { corpo do mendigo } \\
\text { visto como sede das } \\
\text { impurezas que se } \\
\text { quer afastar }\end{array}$ & $\begin{array}{c}\text { • oposição saber } \\
\text { científico/saber } \\
\text { popular: dificuldade } \\
\text { na comunicação } \\
\text { • sistema e } \\
\text { profissionais de } \\
\text { saúde,no geral, vêem } \\
\text { o corpo das mulheres } \\
\text { como objeto a ser } \\
\text { reparado, sem dar a } \\
\text { elas informações } \\
\text { suficientes } \\
\text { profissional/ } \\
\text { usuário : o } \\
\text { conhecimento sobre } \\
\text { o corpo está na mão } \\
\text { dos profissionais de } \\
\text { saúde } \\
\text { conhecimento que } \\
\text { as mulheres têm do } \\
\text { corpo é fragmentado }\end{array}$ & $\begin{array}{c}\bullet \text { oposição } \\
\text { parte/todo do corpo : } \\
\text { questão da } \\
\text { amamentação não é } \\
\text { valorizada na atenção } \\
\text { médica dada à } \\
\text { mulher grávida } \\
\text { • oposição } \\
\text { natureza/ cultura: } \\
\text { possibilidade de } \\
\text { termos uma } \\
\text { sociedade mais } \\
\text { saudável se o direito } \\
\text { natural de mães e } \\
\text { crianças for } \\
\text { respeitado }\end{array}$ & $\begin{array}{c}\text { - oposição } \\
\text { dimensão individual / } \\
\text { coletiva: busca pelo } \\
\text { coletivo da } \\
\text { valorização do corpo } \\
\text { feminino, como forma } \\
\text { de resistência } \\
\text { • oposição } \\
\text { alienação/ } \\
\text { conscientização: } \\
\text { imagem do homem } \\
\text { como alienado e } \\
\text { machista } \\
\text { - sociedade } \\
\text { reforçando a } \\
\text { submissão da } \\
\text { mulher } \\
\text { • oposição } \\
\text { público/privado: } \\
\text { dificuldade em } \\
\text { integrar questões } \\
\text { sociais e coletivas à } \\
\text { vida privada e } \\
\text { doméstica }\end{array}$ & \begin{tabular}{|c} 
• oposição \\
alienação/ \\
conscientização: \\
imagem do homem \\
como alienado e \\
machista \\
• oposição \\
público/privado: \\
mulher como domínio \\
do privado e homem \\
do público \\
• oposição \\
segurança/ risco: \\
questionamento \\
sobre esta questão \\
presente nas \\
relações humanas
\end{tabular} & \begin{tabular}{|} 
• oposição visível \\
(real) / invisível \\
(irreal) : a doença é \\
atribuída aos "outros", \\
nos quais o risco \\
pode ser "visualizado" \\
• oposição eu / \\
outro : a possibilidade \\
da doença está no \\
"outro" e não em \\
"mim" \\
- oposição \\
segurança/ risco: \\
questionamento \\
sobre esta questão \\
presente nas \\
relações humanas
\end{tabular} \\
\hline
\end{tabular}




\section{CORPO POLÍTICO}

\section{VÍDEOS}

\begin{tabular}{|c|c|c|c|c|c|}
\hline $\begin{array}{l}\text { Divina } \\
\text { Previdência }\end{array}$ & Atendimento Médico & $\begin{array}{l}\text { Amamentação: } \\
\text { vamos recuperar } \\
\text { esta prática? }\end{array}$ & Denise & Mancha de Batom & $\begin{array}{l}\text { Quem vê a cara vê } \\
\text { AlDS }\end{array}$ \\
\hline $\begin{array}{c}\text { - oposição } \\
\text { indivíduo/ } \\
\text { sociedade : } \\
\text { poder e } \\
\text { controle das } \\
\text { instituições } \\
\text { sobre o corpo } \\
\text { do indivíduo }\end{array}$ & $\begin{array}{c}\text { • oposição indivíduo/ } \\
\text { sociedade : poder das } \\
\text { instituições de saúde e seus } \\
\text { representantes sobre o corpo } \\
\text { da mulher } \\
\text { - oposição saber científico / } \\
\text { saber popular: autoritarismo } \\
\text { • oposição } \\
\text { pobres/ricos:diferença no } \\
\text { tratamento pelos profissionais; } \\
\text { autoritarismo, falta de atenção } \\
\text { busca da libertação das } \\
\text { mulheres dos poderes } \\
\text { instituídos } \\
\text { oposição conhecimento / } \\
\text { desconhecimento: o } \\
\text { desconhecimento e } \\
\text { fragmentação do corpo } \\
\text { feminino facilita seu controle } \\
\text { por parte da sociedade } \\
\text { (família e outras instituições) }\end{array}$ & $\begin{array}{c}\text { • oposição } \\
\text { indivíduo/ } \\
\text { sociedade : poder } \\
\text { da sociedade } \\
\text { sobre as mulheres } \\
\text { - resgate da } \\
\text { amamentação } \\
\text { enquanto direito de } \\
\text { mulheres e } \\
\text { crianças }\end{array}$ & $\begin{array}{c}\text { - oposição homem/ } \\
\text { mulher: poder do } \\
\text { homem sobre a } \\
\text { mulher } \\
\text { oposição } \\
\text { indivíduo/ sociedade : } \\
\text { poder das instituições } \\
\text { de saúde e seus } \\
\text { representantes sobre } \\
\text { o corpo da mulher } \\
\text { • oposição } \\
\text { conhecimento / } \\
\text { desconhecimento: o } \\
\text { desconhecimento e } \\
\text { fragmentação do } \\
\text { corpo feminino facilita } \\
\text { seu controle por parte } \\
\text { da sociedade (família } \\
\text { e outras instituições) } \\
\bullet \text { busca da } \\
\text { libertação das } \\
\text { mulheres dos poderes } \\
\text { instituídos }\end{array}$ & $\begin{array}{c}\text { - oposição homem/ } \\
\text { mulher: poder do } \\
\text { homem sobre a } \\
\text { mulher } \\
\text { • oposição } \\
\text { conhecimento / } \\
\text { desconhecimento: o } \\
\text { desconhecimento } \\
\text { facilita o controle do } \\
\text { corpo da mulher }\end{array}$ & $\begin{array}{c}\text { - oposição risco/ } \\
\text { segurança: o perigo } \\
\text { da doença para o } \\
\text { corpo individual e } \\
\text { social gera reações } \\
\text { de negação e } \\
\text { afastamento como } \\
\text { forma de controle das } \\
\text { emoções }\end{array}$ \\
\hline
\end{tabular}


São apresentados abaixo quadros que buscam sistematizar a forma como alguns elementos de linguagem (roteiro, edição, movimento de câmera, enquadramento, áudio e cenário) são estruturados visando comunicar a mensagem.

\begin{tabular}{|c|c|c|c|c|c|}
\hline \multicolumn{6}{|c|}{ ROTEIRO (TRATAMENTO DO TEMA) } \\
\hline \multicolumn{6}{|c|}{ VÍDEOS } \\
\hline Divina Previdência & Atendimento Médico & $\begin{array}{l}\text { Amamentação: } \\
\text { vamos recuperar } \\
\text { esta prática? }\end{array}$ & Denise & Mancha de Batom & $\begin{array}{l}\text { Quem vê a cara vê } \\
\text { AIDS }\end{array}$ \\
\hline $\begin{array}{l}\text { - uso de metáforas: } \\
\text { metáfora da ferida da } \\
\text { exclusão social no } \\
\text { corpo do indivíduo } \\
\text { - recursos: drama, } \\
\text { grotesco, ironia } \\
\text { - uso do grotesco e } \\
\text { do drama para forçar } \\
\text { o espectador a } \\
\text { perceber as } \\
\text { contradições }\end{array}$ & $\begin{array}{c}\text { • opção pela } \\
\text { denúncia das más } \\
\text { condições de } \\
\text { atendimento nas filas } \\
\text { dos serviços de } \\
\text { saúde } \\
\text { • utilização das } \\
\text { entrevistas em grupo } \\
\text { visando refletir sobre } \\
\text { a qualidade do } \\
\text { atendimento médico }\end{array}$ & $\begin{array}{l}\text { - } \quad \text { seqüências longas } \\
\bullet \quad \text { linguagem } \\
\text { explicativa, denotativa } \\
\text { - uso da linguagem } \\
\text { científica } \\
\bullet \quad \text { uso de } \\
\text { gráficos/quadros }\end{array}$ & $\begin{array}{c}\text { - alternância de } \\
\text { planos gerais, médios } \\
\text { e detalhes para } \\
\text { compor o discurso } \\
\text { - alternância dos } \\
\text { tempos } \\
\text { (passado/ presente/ } \\
\text { futuro ) na narrativa }\end{array}$ & $\begin{array}{c}\bullet \quad \text { algumas } \\
\text { seqüências longas, } \\
\text { porém com estrutura } \\
\text { narrativa bem } \\
\text { estruturada } \\
\text { - uso do recurso do } \\
\text { humor } \\
\text { - utilização de } \\
\text { recursos de } \\
\text { computação gráfica }\end{array}$ & $\begin{array}{l}\text { - uso do recurso do } \\
\text { humor para se } \\
\text { contapor à estratégia } \\
\text { do medo utilizada } \\
\text { pela campanha } \\
\text { estatal }\end{array}$ \\
\hline
\end{tabular}




\begin{tabular}{|c|c|c|c|c|c|}
\hline \multicolumn{6}{|c|}{ EDIÇÃO } \\
\hline \multicolumn{6}{|c|}{ VÍDEOS } \\
\hline Divina Previdência & Atendimento Médico & $\begin{array}{l}\text { Amamentação } \\
\text { vamos recuperar } \\
\text { esta prática }\end{array}$ & Denise & Mancha de Batom & $\begin{array}{l}\text { Quem vê a cara vê } \\
\text { AIDS }\end{array}$ \\
\hline $\begin{array}{l}\text { - } \quad \text { imagens editadas } \\
\text { visando criar um } \\
\text { clima dramático } \\
\text { - } \quad \text { preocupação com } \\
\text { o ritmo }\end{array}$ & $\begin{array}{l}\text { - } \text { interligação das } \\
\text { imagens visa } \\
\text { descrever as } \\
\text { situações para } \\
\text { construir uma idéia }\end{array}$ & $\begin{array}{l}\text { - } \quad \text { interligação das } \\
\text { imagens visa } \\
\text { descrever as } \\
\text { situações para } \\
\text { construir uma idéia }\end{array}$ & $\begin{array}{c}\text { • edição ágil } \\
\text { - inserção de } \\
\text { imagens em detalhes } \\
\text { como complemento } \\
\text { • inserção de } \\
\text { imagens de } \\
\text { flashbacks ou de } \\
\text { situações imaginadas } \\
\text { pela protagonista } \\
\text { - preocupação com } \\
\text { o ritmo }\end{array}$ & $\begin{array}{l}\text { - edição ágil } \\
\text { - preocupação com } \\
\text { o ritmo } \\
\text { - construção } \\
\text { narrativa com } \\
\text { alternância de cenas } \\
\text { segundo o ponto de } \\
\text { vista dos dois } \\
\text { personagens } \\
\text { principais }\end{array}$ & $\begin{array}{c}\text { - } \text { interligação das } \\
\text { imagens visa } \\
\text { construir uma idéia } \\
\text { - } \quad \text { preocupação com } \\
\text { o ritmo }\end{array}$ \\
\hline
\end{tabular}


MOVIMENTO DE CÂMERA E ENQUADRAMENTOS

\begin{tabular}{|c|c|c|c|c|c|}
\hline \multicolumn{6}{|c|}{ VÍDEOS } \\
\hline Divina Previdência & Atendimento Médico & $\begin{array}{l}\text { Amamentação: } \\
\text { vamos recuperar } \\
\text { esta prática? }\end{array}$ & Denise & Mancha de Batom & $\begin{array}{l}\text { Quem vê a cara vê } \\
\text { AIDS }\end{array}$ \\
\hline \begin{tabular}{|c|} 
- função dramática \\
ou psicológica \\
- utilização de \\
closes e primeiro \\
plano como recurso \\
expressivo \\
- rostos anônimos - \\
closes \\
- utilização de \\
vários ângulos de \\
enquadramento \\
colaborando na \\
construção do sentido \\
do discurso
\end{tabular} & $\begin{array}{c}\text { - alternância entre } \\
\text { planos gerais, médios } \\
\text { e closes } \\
\text { - movimentos de } \\
\text { câmera têm uma } \\
\text { função descritiva }\end{array}$ & $\begin{array}{l}\text { - } \text { predominância de } \\
\text { planos gerais e } \\
\text { médios } \\
\text { - utilização de } \\
\text { closes nas cenas de } \\
\text { amamentação e em } \\
\text { alguns depoimentos } \\
\text { - movimentos de } \\
\text { câmera têm uma } \\
\text { função descritiva }\end{array}$ & $\begin{array}{c}\text { - } \text { alternância entre } \\
\text { planos gerais, médios } \\
\text { e closes } \\
\text { - utilização de } \\
\text { planos de detalhes } \\
\text { - movimentos de } \\
\text { câmera têm uma } \\
\text { função rítmica }\end{array}$ & $\begin{array}{c}\text { • alternância entre } \\
\text { planos gerais, médios } \\
\text { e closes } \\
\text { - movimentos de } \\
\text { câmera têm uma } \\
\text { função rítmica } \\
\text { - utilização de } \\
\text { vários ângulos de } \\
\text { enquadramento } \\
\text { colaborando na } \\
\text { construção do sentido } \\
\text { do discurso }\end{array}$ & $\begin{array}{l}\text { - predominância de } \\
\text { planos gerais e } \\
\text { médios } \\
\text { - movimentos de } \\
\text { câmera têm uma } \\
\text { função descritiva }\end{array}$ \\
\hline
\end{tabular}




\begin{tabular}{|c|c|c|c|c|c|}
\hline \multicolumn{6}{|c|}{ ÁUDIO } \\
\hline \multicolumn{6}{|c|}{ VÍDEOS } \\
\hline Divina Previdência & Atendimento Médico & $\begin{array}{l}\text { Amamentação: } \\
\text { vamos recuperar } \\
\text { esta prática? }\end{array}$ & Denise & Mancha de Batom & $\begin{array}{l}\text { Quem vê a cara vê } \\
\text { AIDS }\end{array}$ \\
\hline $\begin{array}{l}\text { • o personagem } \\
\text { principal não tem voz; } \\
\text { a voz é a dos } \\
\text { representantes da } \\
\text { instituição que } \\
\text { apresentam um } \\
\text { discurso impositivo } \\
\text { - discurso agressivo } \\
\text { das cenas finais } \\
\text { representam a visão } \\
\text { que uma parte da } \\
\text { sociedade tem dos } \\
\text { excluídos } \\
\text { - músicas no início } \\
\text { e final reforçam o } \\
\text { paradoxo, servem de } \\
\text { contraponto; durante } \\
\text { as cenas de tensão } \\
\text { reforçam o clima } \\
\text { - utilização do som } \\
\text { de programa de rádio }\end{array}$ & $\bullet$ & $\begin{array}{l}\text { - a letra da música } \\
\text { que inicia e finaliza o } \\
\text { vídeo é muito } \\
\text { importante na } \\
\text { construção do sentido }\end{array}$ & $\begin{array}{l}\text { • } \quad \text { músicas com } \\
\text { letras complementam } \\
\text { as imagens } \\
\text { - utilização do som } \\
\text { de programa de rádio } \\
\text { - utilização de } \\
\text { ruídos }\end{array}$ & \begin{tabular}{|c} 
- utilização do som \\
de programa de rádio \\
com humor \\
utilização de \\
ruídos \\
- voz dos \\
entrevistados nas \\
ruas trazendo a visão \\
da sociedade sobre o \\
tema do vídeo
\end{tabular} & $\begin{array}{c}\text { • utilização de } \\
\text { músicas com letras } \\
\text { que servem de } \\
\text { contraponto e reforço } \\
\text { - voz do repórter e } \\
\text { da população nas } \\
\text { ruas }\end{array}$ \\
\hline
\end{tabular}




\begin{tabular}{|c|c|c|c|c|c|}
\hline \multicolumn{6}{|c|}{ CENÁRIO } \\
\hline \multicolumn{6}{|c|}{ VÍDEOS } \\
\hline Divina Previdência & Atendimento Médico & $\begin{array}{l}\text { Amamentação: } \\
\text { vamos recuperar } \\
\text { esta prática? }\end{array}$ & Denise & Mancha de Batom & $\begin{array}{l}\text { Quem vê a cara vê } \\
\text { AIDS }\end{array}$ \\
\hline $\begin{array}{l}\text { - locais externos } \\
\text { realistas ; } \\
\text { internamente em } \\
\text { cenários reais , mas } \\
\text { produzidos para as } \\
\text { cenas }\end{array}$ & $\begin{array}{l}\text { - locais internos e } \\
\text { externos realistas }\end{array}$ & $\begin{array}{l}\text { - locais internos e } \\
\text { externos realistas }\end{array}$ & $\begin{array}{l}\text { - locais externos } \\
\text { realistas ; } \\
\text { internamente em } \\
\text { cenários reais, mas } \\
\text { produzidos para as } \\
\text { cenas }\end{array}$ & $\begin{array}{l}\text { - construído e } \\
\text { estilizado } \\
\text { - } \quad \text { entrevistas em } \\
\text { cenário realista }\end{array}$ & $\begin{array}{l}\text { - locais externos } \\
\text { realistas }\end{array}$ \\
\hline
\end{tabular}

Os quadros abaixo referem-se às funções de linguagem prioritárias observadas em cada material, assim como as diferenças observadas na configuração dos elementos de linguagem entre os dois gêneros de produtos comunicativos.

QUADRO 9:

\begin{tabular}{|c|c|c|c|c|c|}
\hline \multicolumn{6}{|c|}{ FUNÇÕES DA LINGUAGEM } \\
\hline \multicolumn{6}{|c|}{ VÍDEOS } \\
\hline Divina Previdência & Atendimento Médico & $\begin{array}{l}\text { Amamentação: } \\
\text { vamos recuperar } \\
\text { esta prática? }\end{array}$ & Denise & Mancha de Batom & $\begin{array}{l}\text { Quem vê a cara vê } \\
\text { AIDS }\end{array}$ \\
\hline $\begin{array}{l}\text { - } \quad \text { função emotiva } \\
\bullet \quad \text { função } \\
\text { metalingüística }\end{array}$ & $\begin{array}{l}\text { - função referencial } \\
\text { - função emotiva }\end{array}$ & $\begin{array}{l}\text { - } \quad \text { função referencial } \\
\text { - } \quad \text { função emotiva }\end{array}$ & - função emotiva & $\begin{array}{l}\text { - } \quad \text { função emotiva } \\
\text { - função fática } \\
\text { • função } \\
\text { metalingüística }\end{array}$ & - função fática \\
\hline
\end{tabular}




\begin{tabular}{|c|c|c|}
\hline \multirow{2}{*}{ ELEMENTOS DE LINGUAGEM } & \multicolumn{2}{|c|}{ GÊNERO * } \\
\hline & FICÇÃO & REPORTAGEM/ DOCUMENTÁRIO \\
\hline $\begin{array}{l}\text { MOVIMENTO DE CÂMERA E } \\
\text { ENQUADRAMENTOS }\end{array}$ & $\begin{array}{c}\text { - enquadramentos mais fechados, em primeiro } \\
\text { plano e detalhes } \\
\text { - função dramática ou psicológica }\end{array}$ & $\begin{array}{c}\text { - } \text { maior presença de planos gerais e médios } \\
\text { - movimentos de câmera: função descritiva } \\
\bullet \quad \text { ponto de vista objetivo }\end{array}$ \\
\hline ÁUDIO & $\begin{array}{c}\text { - músicas complementam , servem de } \\
\text { contraponto ou divergem das imagens, } \\
\text { contribuindo para a construção da narrativa; } \\
\text { utilização de ruídos }\end{array}$ & $\begin{array}{c}\text { • músicas : maior redundância } \\
\text { - utilização de voz em off explicando as } \\
\text { imagens }\end{array}$ \\
\hline ROTEIRO & $\begin{array}{l}\text { - utilização do humor/ grotesco/ drama } \\
\text { • uso de metáforas }\end{array}$ & $\begin{array}{l}\text { - maior preocupação com encadeamento } \\
\text { lógico/racional do discurso (textos em off, } \\
\text { entrevistas, depoimentos) } \\
\text { - preocupação com a "verdade", fidedignidade } \\
\text { das informações }\end{array}$ \\
\hline CENÁRIO & $\begin{array}{l}\text { - construído ou adaptado a partir de locações } \\
\text { realistas; valorização dos detalhes; } \\
\text { predominância de cenas em interiores }\end{array}$ & $\begin{array}{c}\text { - maior realismo; predominância da } \\
\text { impessoalidade; predominância de cenas } \\
\text { externas }\end{array}$ \\
\hline EDIÇÃO & - inserção de momentos passados e futuros & - linear, harmônica, ordem cronológica \\
\hline
\end{tabular}

* Gênero é entendido aqui como "estratégia de comunicabilidade" (BARBERO, 1997, p.302 ), como forma de interação entre produtores e público. 


\section{CONSIDERAÇÕES FINAIS E CONCLUSÕES}

A partir das observações realizadas apresentamos a seguir algumas considerações sobre a representação do corpo, assim como sugestões quanto a formatação dos vídeos.

- A aproximação dos objetos, a visão em detalhe, ressaltando o que normalmente não se vê na realidade, é uma característica das produções em vídeo. Como MACHADO (1988) aponta, estas produções utilizam-se de closes e primeiros planos. Estes recursos podem propiciar de uma forma mais adequada a relação corporal citada por LANDOWSKI (1996) na p. 26 deste trabalho e tem a ver também com o que coloca AUMONT (1995) sobre a visão de perto, ou pólo háptico (tátil), que representa um dos modos de visão do objeto no espaço. Nessas situações, através da imagem, quase se pode sentir os objetos e criar uma maior intimidade com os personagens. Desta forma deve-se explorar ao máximo os recursos específicos e adequados para uma maior eficácia na comunicação.

- Como a apreensão das imagens depende fundamentalmente da percepção é interessante que os materiais audiovisuais trabalhem com o nível instintivo de percepção da imagem, reforçando características de cores e formas que constituem-se elementos emotivos por excelência.

- É importante pensar na função emotiva na configuração dos materiais, pois desta forma a partir da expressão das emoções por parte dos emissores da mensagem, pode-se estimular a identificação, sensibilizar o público através de suas próprias emoções e suscitar discussões a respeito de conteúdos não racionalizados.

- Com relação à questão do som é importante refletir sobre como integrar os sons (depoimentos, diálogos, entrevistas, músicas, ruídos) e as imagens 
para enriquecer o material e atrair o espectador. Além disto é necessário questionar-se a utilização do "off" nos padrões que vemos normalmente nos produtos televisuais: uma voz neutra, explicando as imagens. Como foi levantado anteriormente, pode gerar um distanciamento que dificulte o envolvimento emocional do espectador. A idéia do som nos materiais audiovisuais é de estimular a imaginação, para não quebrar a riqueza e abertura da imagem em fornecer vários significados. Ao utilizar-se de um discurso muito diretivo aciona-se primeiramente o envolvimento intelectual do espectador com o vídeo. De acordo com BETTON (1987) ao fazermos o caminho inverso permite-se com que se acione primeiro a afetividade do receptor e só depois a sua inteligência.

- Dois vídeos ( Mancha de batom e Quem vê cara vê aids) buscam em algum momento a interlocução direta com o corpo do espectador, isto é, o repórter, ou a protagonista , no caso da ficção, falam para o espectador , olham e se aproximam da câmera, configurando a função fática. Este recurso pode ser útil para capturar o interesse da audiência.

- Citando Vanoye, AUMONT (1995) fala sobre "como certos filmes "administram" melhor o ciclo emocional, ao "permitirem ao espectador acesso à integração ou à elaboração de sua experiência emocional" por domínio da configuração narrativa (....) o que comove é a participação em um mundo ficcional, a relação com personagens, o confronto com situações". (AUMONT, 1995, p.123). Dois dos vídeos ficcionais (Denise e Mancha de Batom) possibilitam que as emoções sejam melhor "administradas"; eles fornecem leituras das várias questões apresentadas ( DST, sexualidade, planejamento familiar, etc.) sobre o ponto de vista de vários personagens, colaborando para integrar várias emoções, na medida em que os problemas são vistos sob vários ângulos. Além da estrutura narrativa construída, as próprias imagens escolhidas, em si, pela sua diversidade e formas de apresentação, colaboram neste sentido. 
- Nos produtos ficcionais a edição desempenha um papel mais significativo na construção da narrativa, não só como corte de um bloco para outro. Os materiais são editados de uma forma mais criativa, são mais recortados e inserem-se mais imagens de detalhes. MACHADO (1988) diz que esta forma de trabalhar a imagem, mais fragmentada, é mais adequada ao vídeo do que planos gerais e cenas com longa duração.

- Identificaram-se algumas oposições básicas na forma de configuração do corpo que são as linhas que conduzem o desenrolar dos vídeos. Em alguns percebe-se a intenção de acentuar as contradições, polemizando de uma forma mais contundente. Em "Divina Previdência", por ex, a ênfase é na contradição, no paradoxo, apontado pelo grotesco. O excesso se mostra como uma opção artística, e até política, colaborando para mostrar com mais veemência as contradições. Em outros materiais (por ex. em "Amamentação") a oposição é apontada, porém nota-se uma tendência a buscar a superação das contradições pela opção por um dos pólos. A linguagem do humor, presente em outros vídeos, possibilita que as contradições sejam ressaltadas.

- Ressaltamos a Importância de que sejam representadas faces dos três corpos para que seja possível ampliar a discussão. Consideramos ser importante a representação do corpo individual /existencial, pois pode facilitar a identificação do espectador com as emoções que os indivíduos expressam. O discurso na primeira pessoa, seja através de depoimentos , no caso das reportagens, ou fala pessoal de um personagem, no caso da fiç̧ão, ou mesmo utilização de câmera subjetiva (em que a câmera funciona como o olho do personagem e encaminha a visão do espectador por este ponto de vista), podem colaborar na configuração do corpo individual/existencial. Por vivermos num momento histórico em que o individualismo é um traço constitutivo de nossa cultura, acreditamos ser fundamental, para uma melhor compreensão da mensagem comunicativa, que o ponto de vista individual esteja representado. 
- Quando se configura o corpo individual existe uma tendência para se tocar mais nas emoções, levando o espectador a uma empatia ou repulsa (como no caso de "Divina Previdência"); toca-se mais nos sentidos, no próprio corpo do espectador, propiciando que o significado do se quer apontar seja transmitido de uma forma mais completa.

- Com relação à abordagem do corpo político pode-se perceber que a busca de um maior conhecimento sobre o corpo e uma maior conscientização dos mecanismos de poder a que as mulheres estão submetidas são como um mecanismo de resistência ao poder imposto e vistas como um dos passos necessários à liberação de seus corpos (vide os vídeos Mancha de Batom, Denise e Atendimento Médico).

- O produto audiovisual necessita ser pensado como um recurso comunicativo no qual a ênfase a ser dada não deve se ater apenas ao contexto da mensagem. É importante que se pense na configuração da mensagem e no destinatário. Sua linguagem visual e sonora precisa ser trabalhada técnicamente, não se pode pensar só no que dizer, mas como dizer. O tipo de linguagem pode ser mais leve e os recursos podem ser elaborados dando um espaço maior para a criatividade. Algumas vezes entra em cena também a criação artística, como no caso do vídeo Divina Previdência, que não tem a forma de um discurso elaborado de acordo com os modelos científicos e acadêmicos, mas não deixa, por essa razão, de ter uma função educativa.

- Consideramos que se deva valorizar o trabalho com os recursos de linguagem para aproveitar mais as possibilidades do meio; a idéia de apresentar o vídeo inserido em atividades educativas possibilita que discussões posteriores possam ser um momento para reflexões; o vídeo não precisa tratar $\mathrm{o}$ assunto exaustivamente. 
Concluímos que:

- A utilização das categorias de corpo individual/existencial, social e político, são úteis como instrumentos de análise da representação do corpo nos vídeos, pois fornecem elementos que propiciam uma leitura dos diversos condicionamentos aos quais o corpo dos indivíduos está submetido. As interpretações que decorrem desta análise podem ser valiosas para as discussões e reflexões a serem desencadeadas com a exibição dos vídeos, complementando o processo educativo.

- A abordagem do corpo através destas três perspectivas colabora para a fortalecer a idéia de que as concepções que temos sobre o corpo, assim como a forma de lidarmos com ele, não são naturais, mas culturalmente e historicamente condicionadas. Consideramos que esta visão é importante no sentido de que os diversos pontos de vista necessitam ser compreendidos e respeitados quando se pretende trabalhar na promoção e educação em saúde numa perspectiva democrática .

- A análise dos diversos recursos de linguagem utilizados no processo de construção do produto audiovisual, ao clarear a forma de estruturação do material, assim como o ponto de vista de apresentação do corpo, enriquece a interpretação de como as várias dimensões deste corpo são representadas. 


\section{REFERÊNCIAS BIBLIOGRÁFICAS}

Alsina, MR. Los modelos de la comunicacion. Madrid: Tecnos; 1989. Lo modelo de Jakobson; p.54-64.

Alves BM e Pitanguy J. O que é feminismo. São Paulo: Abril Cultural: Brasiliense; 1985.Coleção Primeiros Passos; 20

Arborelius E, Timpka T.In what way videotapes be used to get significant information about the patient-physician relationship? Med Teach 1990;12(2):197-208

Aumont J. A Imagem. Campinas, SP: Papirus Editora; 1993

Aumont J. A Imagem. Campinas, SP: Papirus Editora; 1995

Balogh, AM. Conjunções, Disjunções, Transmutações. Da literatura ao cinema e à tv. São Paulo: Annablume ECA-USP; 1996

Barbero, Jesus Martin. Dos meios às mediações. Rio de Janeiro: Ed UFRJ; 1997.Os métodos: dos meios às mediações;p.258-334

Barthes R. A câmara clara: nota sobre a fotografia. Rio de Janeiro, RJ: Nova Fronteira; 1984

Berger PL, Luckmann T. A construção social da realidade. Petrópolis, RJ: Editora Vozes Ltda; 1978

Betton G. Estética do cinema. São Paulo: Martins Fontes; 1987 
Birman J. As figuras do analista no cinema: sobre a psicanálise, a modernidade e as novas formas do saber sobre o psíquico. Rio de Janeiro: UERJ, IMS, 1996 (Série Estudos em Saúde Coletiva ; n. 142)

Boltanski L. As classes sociais e o corpo. Rio de Janeiro: Edições Graal. 1979. A relação doente - médico; p.37-68

Boltanski L. As classes sociais e o corpo. Rio de Janeiro: Edições Graal. 1979.A emissão discurso sobre a doença; p.69-84

Candeias NMF. Algumas considerações sobre os conceitos de educação e de promoção em saúde - Mudanças individuais e mudanças organizacionais. Rev Saúde Pública. 1997; 31(2):209-213

Canguilhem G .Machine and Organism. New York. Crary et al, eds. Incorporations Urzone, 1992

Chevalier J, Gheerbrant A. Dicionário de Símbolos . Rio de Janeiro: José Olympio Editora. 1997

Comparato D. Roteiro: Arte e técnica de escrever para cinema e televisão. Rio de Janeiro: Editorial Nórdica. 1983

Couchman W. Using video and conversational analysis to train staff working with people with learning disabilities. J Adv Nurs 1995 Dec; 22(6): 11121119

Csordas T. Embodiment as a paradigm for anthropology. Ethos. 1990; vol $18: 1 ; p .5-47$

Dodd B, Plant G, Gregory M. Teaching lip-reading: the efficacy of lessons on video. Br J Audiol .1989 Aug; 23(3):229-238 
Douglas M. Natural Symbols . New York: Pantheon Books ; 1970. The two bodies; p.65-81

Ewles L , Simnett I . Promoting health: a pratical guide. UK: Sartori Press, 1992. Using and producing health promotion materials; p. 226-257

Ferreira OMC, Silva Jr PD. Recursos audiovisuais no processo ensinoaprendizagem. São Paulo: Editora Pedagógica e Universitária; 1986

Foucault M. O nascimento da clínica. Rio de Janeiro: ForenseUniversitária; 1984. Espaços e classes; p.1-21

Foucault M. O nascimento da clínica. Rio de Janeiro: ForenseUniversitária; 1984.Signos e casos; p. 99-120

Geertz C. A interpretação das culturas. Rio de Janeiro: Zahar ; 1978. Uma descrição densa: por uma teoria interpretativa da cultura; p.13-41

Geertz C. A interpretação das culturas. Rio de Janeiro: Zahar ; 1978. O impacto do conceito de cultura sobre o conceito de homem; p.45-66

Giacomantonio M. O ensino através dos audiovisuais. São Paulo: Summus/ Editora da Universidade de São Paulo; 1981

Gutiérrez F. Linguagem Total. São Paulo: Summus; 1978

Harper DC, Wadsworth JS . Improving health care communication for persons with mental retardation. Public Health Rep 1992 May;107(3):297302 
Honkasalo M-L . Space and embodied experience: rethinking the body in pain. Body \& Society. Sage; 1998; vol 4.(2) June

Jakobson, R. Lingüística e comunicação. São Paulo: Editora Cultrix / Editora da Universidade de São Paulo; 1969 . Lingüística e poética; p.118162

Jakobson, R. Lingüística, poética e cinema. São Paulo: Editora Perspectiva; 1970. Decadência do cinema? ; p.153-161

Landowski E. Viagem às nascentes do sentido. In: Ignacio Assis Silva (org). Corpo e sentido: a escuta do sensível. São Paulo: Editora da Universidade Estadual Paulista; 1996 (p21-43)

Longhi J, Ewert RE, Equipe Jatalon. Vídeo Independente. São Paulo: Summus Editorial; 1987

Le Goff J. Head or Heart? The political use of body methafors in the middle ages. In : Feher $M$, Naddaff $R$. Fragments for a history of the human body. Part Three. New York: Zone; 1989 (p.13-27)

Lupton D. Risk as moral danger: the social and political functions of risk discourses in public health. International Journal of Health Services.1993; 23(3):425-435

Machado A. A arte do vídeo. São Paulo: Brasiliense; 1988

Machado A. O vídeo e sua linguagem. São Paulo; 1993.[Boletim da Associação Brasileira de Vídeo Popular $n{ }^{\circ} 18$ Março/Abril ; p.5-11]

Machado A. Máquina e imaginário. São Paulo: EDUSP; 1996. A experiência do vídeo no Brasil; p.253-274. 
Makoul G, Arntson P, Schofield T. Helth promotion in primary care: physician-patient communication and decision making about prescription medications. Soc Sci Med 1995 Nov; 41(9):1241-1254

Mauss M. Sociologia e Antropologia. São Paulo: EPU/EDUSP; 1974, vol2. Técnicas corporais ; p.209-230

Mauss M. Sociologia e Antropologia. São Paulo: EPU/EDUSP; 1974. Uma categoria do espírito humano: a noção de pessoa, a noção do "eu“; p.207241

Meade CD. Producing videotapes for cancer education: methods and examples. Oncol Nurs Forum 1996 Jun; 23(5):837-846

Mearleau-Ponty M. Fenomenologia da percepção. RJ: Livraria Freitas Bastos; 1971. O corpo; p.80-209

Melo J. Trabalho de formiga em terra de tamanduá .A experiência feminista com vídeo. São Paulo; 1993. [Tese de Mestrado - ECA/USP]

Metz C. Além da analogia, a imagem. In: Metz C, Durand J, Perinou G, Marin L, Schefer J-L . A análise das imagens. Petrópolis , RJ. Vozes; 1974

Moran JM . Leituras dos meios de comunicação. São Paulo: Pancast; 1993

Morin E. A alma do cinema . In: Xavier I , organizador. A experiência do cinema. Rio: Graal-Embrafilme ; 1983

Naidoo J , Wills J . Health Promotion: Foundations for Practice. UK: Ballière Tinall, 1994.Models and approaches to health promotion; p. 83-100 
Naidoo J , Wills J . Health Promotion: Foundations for Practice. UK:

Ballière Tinall, 1994. Using the mass media in health promotion; p. 269-278

Oliveira EM. Corpo-cidadania: a conquista da mulher . In: Régia M, Lima MJ, Baião I, Xavier D, Camurça S, Oliveira EM. Como trabalhar com mulheres. Rio de Janeiro: Editora Vozes; 1988. p.70-93.

O’Neill J. Five Bodies. New York: Cornell University Press; 1985. Social Bodies; p.48-66

Palmer D. Mass media for health promotion: health leninists or change agents? . Aust J Public Health. 1992 Jun; 16(2):206-7

Passarelli, CAF. Imagens em diálogo: filmes que marcaram nossas vidas. In: Spink MJ, organizadora. Práticas discursivas e produção de sentidos no cotidiano. São Paulo: Cortez Editora; 1999. p 273-283.

Rodrigues JC. O corpo na história. Rio de Janeiro: Editora Fiocruz; 1999.

Ryan GW, Martinez H, Pelto GH. Methodological issues for eliciting local signs/symptoms/illness terms associated with acute respiratory illnesses. Arch Med Res 1996; 27(3):359-365

Santaella L e Nöth W. Imagem. São Paulo: Iluminuras ; 1997.

Santoro, LF . A Imagem nas mãos. O vídeo popular no Brasil. São Paulo: Summus Editorial; 1989. O vídeo como meio de comunicação; p.17-34

Santoro, LF . A Imagem nas mãos. O vídeo popular no Brasil. São Paulo: Summus Editorial; 1989. O vídeo popular no Brasil; p. 59-83 
Scheper-Hughes N , Lock M. The Mindful Body:a prolegomenom to future work in medical anthropology . Medical Anthropology Quarterly . 1987; vol1 n1 March : 6-84

Scott A.The symbolizing Body and the methaphysics of alternative medicine. Body \& Society. Sage; 1998; vol 4(3) September

Secretaria Municipal da Saúde de São Paulo. Centro de Formação dos Trabalhadores da Saúde. Caderno de Atividades Realizadas nos anos de 1991 e 1992.São Paulo; Maio de 1992

Siqueira, VHF, Vargas EP. Sexualidade e corpo: o olhar do sujeito através das imagens em vídeo. Cadernos de Saúde Pública. Rio de Janeiro.1999; 15 (Sup.2): 69-83

Silva AM. Elementos para compreender a modernidade do corpo numa sociedade racional. Caderno CEDES. Campinas. 1999; vol 19 n 48 [ "on line" via Internet : www.scielo.br / maio 2001]

Sontag S. Aids e suas metáforas. São Paulo: Companhia das Letras; 1989 Strathern A. Body Thougths. Michigan.1996. Habit or habitus; p.25-39

Strathern A. Body Thougths. Michigan.1996. Embodiment; p.177-204

Strathern A. Body Thougths. Michigan.1996. The biomedical body: configurations of science and gender; p.139-151

Taussig MT. Reification and the consciousness of the patient. Social Science and Medicine.1980;14b(1):3-14

Turner BS. El cuerpo y la sociedad. Exploraciones en teoria social. Mexico: Fondo de Cultura Economica; 1989 
Watson J, Cunningham-Burley S, Watson N, Milburn K. Lay theorizing about "the body" and implications for health promotion. Health Education Research. 1996; 11(2): 161-172

Winett RA, Anderson ES, Moore JF, Taylor CD, Hook RJ, Webster DA et. al. Efficacy of a home-based human immunodeficiency virus prevention video program for teens and parents. Health Educ Q .1993; 20(4): 555-567 


\section{ANEXO 1}

\section{Assuntos reagrupados em categorias mais genéricas:}

1. adolescente

2. adolescentes (geral/ drogas/gravidez/ sexualidade)

3. aids / dst

4. alcoolismo

5. câncer

6. cólera

7. comportamento

8. demografia

9. dengue

10. diabetes

11. drogas

12. educação em saúde

13. ervas

14. hanseníase

15. hipertensão

16. idoso
17. malária

18. medicamentos

19. mulher

20. nutrição

21. participação

22. qualidade vida

23. reprodução humana

24. recursos humanos

25. saúde bucal

26. saúde criança

27. saúde mental

28. saúde mulher (geral/ aborto/ aleitamento/ anticoncepção)

29. saúde trabalhador

30. serviços saúde /serviços públicos

31. tuberculose

32. vigilância sanitária 